Universidade de São Paulo

Escola Superior de Agricultura "Luiz de Queiroz"

Desafio de laranjeiras doces geneticamente modificadas à infecção por

Candidatus Liberibacter asiaticus e Xanthomonas citri subsp. citri

\title{
Matheus Luís Docema
}

Tese apresentada para obtenção do título de Doutor em Ciências. Área de concentração: Fitotecnia

Piracicaba

2021 


\section{Matheus Luís Docema \\ Engenheiro Agrônomo}

Desafio de laranjeiras doces geneticamente modificadas à infecção por Candidatus Liberibacter asiaticus e Xanthomonas citri subsp. citri

versão revisada de acordo com a resolução CoPGr 6018 de 2011

Orientador:

Prof. Dr. FRANCISCO DE ASSIS ALVES MOURÃO FILHO

Tese apresentada para obtenção do título de Doutor em Ciências. Área de concentração: Fitotecnia 
Dados Internacionais de Catalogação na Publicação DIVISÃO DE BIBLIOTECA - DIBD/ESALQ/USP

Docema, Matheus Luís

Desafio de laranjeiras doces geneticamente modificadas à infecção por Candidatus Liberibacter asiaticus e Xanthomonas citri subsp. citri / Matheus Luís Docema. - - versão revisada de acordo com a resolução CoPGr 6018 de 2011. - - Piracicaba, 2021.

$126 \mathrm{p}$.

Tese (Doutorado) - - USP / Escola Superior de Agricultura "Luiz de Queiroz".

1. Citrus sinensis 2. Transformação genética 3. Resistência a doenças 4. Bactérias I. Título 
Dedico a todos os Filhos da Gloriosa,

HINO DA ESCOLA SUPERIOR DE AGRICULTURA 'LUIZ DE QUEIROZ'

\author{
A água, o sol e a terra \\ Existem com própria beleza. \\ As plantas silentes e sempre, \\ Sustêm o equilíbrio \\ Dos ciclos da natureza. \\ Plantar, criar e conservar. \\ A ESALQ existe p'ra ensinar; \\ Cumprindo missão vitoriosa. \\ Vem inspirar deusa Ceres, \\ Os filhos da gloriosa, \\ Que partem pelo Brasil, \\ A propalar de norte a sul, \\ Cumprindo missão vitoriosa. \\ Plantar, criar e conservar. \\ A ESALQ existe p'ra ensinar; \\ Cumprindo missão vitoriosa.
}

Letra: Zilmar Ziller Marcos (1955) 


\section{AGRADECIMENTOS}

A Deus por ter me dado mais uma oportunidade de continuar amadurecendo pessoalmente e profissionalmente, além de todas as bênçãos e ensinamentos que me concede diariamente em minha vida.

Ao idealizador Luiz Vicente de Souza Queiroz, pela construção dessa imponente obra, a Escola Superior de Agricultura "Luiz de Queiroz", onde tive a honra de receber o título de Engenheiro Agrônomo da $110^{\text {a }}$ turma de formandos, o troféu 'A encarnado' e o privilégio de realizar o curso de mestrado e doutorado no Programa de Fitotecnia desta Universidade.

Ao Conselho Nacional de Desenvolvimento Científico e Tecnológico (CNPq), pela concessão da bolsa de estudos de doutorado (Processo 140075/2017-8) e demais apoios financeiros para a realização desta pesquisa.

À Universidade Virtual do Estado de São Paulo (UNIVESP), pela oportunidade de atuar no programa de Formação Didático-Pedagógica para Cursos na Modalidade a Distância, e por toda a experiência adquirida no processo de facilitação de aprendizagem.

Ao Prof. Dr. Francisco de Assis Alves Mourão Filho pela orientação, sabedoria, disciplina e entusiasmo demonstrado a cada meta conquistada de seus alunos. Agradeço aos seus valiosos ensinamentos que os tornam exemplo de uma conduta ética e profissional, contribuindo enfaticamente para meu amadurecimento pessoal e acadêmico. Concluo essa importante etapa de minha vida profissional com um grande aprendizado por ele citado incessantemente '... Não tenho compromisso com o erro'.

Aos (Às) demais professores (as) e pesquisadores (as) que contribuíram para a execução deste trabalho, em especial, ao Prof. Dr. José Belasque Jr, à Prof ${ }^{a}$. Dra. Beatriz Appezzatoda-Glória, ao Prof. Dr. Ricardo Antunes de Azevedo, ao Prof. Dr. Hudson Wallace Pereira de Carvalho, à Prof ${ }^{a}$. Dra. Sônia Maria De Stefano Piedade, ao Dr. João Paulo Rodrigues Marques e à Dra. Eveline Carla da Rocha Tavano. Agradeço também as valiosas contribuições dos pesquisadores, Dra. Juliana de Freitas Astua e Dr. Ricardo Harakava que me coorientaram durante a condução da tese, compondo o Comitê de Acompanhamento (COA). Estendo os agradecimentos aos pesquisadores e parceiros que integram a rede multidisciplinar do Instituto Nacional de Ciência e Tecnologia de Genômica para o Melhoramento de Citros (INCT-Citros).

Aos integrantes do Laboratório de Biotecnologia de Plantas Hortícolas (ESALQ/USP), em especial à minha amiga Dra. Liliane Cristina Liborio Stipp por todos os 
ensinamentos, companheirismo, sugestões e auxílios na realização de análises moleculares e demais atividades de laboratório.

A todos os funcionários e técnicos da Escola Superior de Agricultura "Luiz de Queiroz" pelos suportes e contribuições na execução de análises laboratoriais e de atividades de casa de vegetação ou campo, em especial Aparecido Donizete Serrano, Éder de Araújo Cintra, Antônio Carlos Fernandes, Marli Kasue Misaki Soares e Dra. Salete Aparecida Gaziola.

Aos meus parentes e à minha amada família, especialmente ao meu pai Márcio Antônio Docema, à minha mãe Maria Aparecida Silva Docema, aos meus irmãos Thiago Luís Docema e Letícia Maria Docema por todas as manifestações de carinho e demais contribuições em minha formação pessoal, profissional, ética e humana. À minha namorada Jaciara Schulenburg Stacholski pelo apoio e companheirismo, mesmo que a distância, neste importante momento de minha vida.

Aos colegas de graduação, pós-graduação, aos amigos do peito Ricardo Medina, Fabio Viesi e Caio Morais de Alcântara Barbosa, e a todos os demais amigos que, gentilmente, colaboraram no auxílio dos meus experimentos em laboratórios e/ou em casa de vegetação.

Aos amigos da equipe de Futebol de Campo da Associação Atlética Acadêmica "Luiz de Queiroz" (AAALQ), pelas inúmeras conquistas, treinos, confraternizações, campeonatos universitários, que juntos totalizaram memoráveis 21 títulos conquistados durante os doze anos em que estive presente como zagueiro e capitão do time de futebol de campo da AAALQ.

A todos que de alguma forma contribuíram para a realização deste trabalho, mesmo que por orações e pensamentos positivos. 


\section{SUMÁRIO}

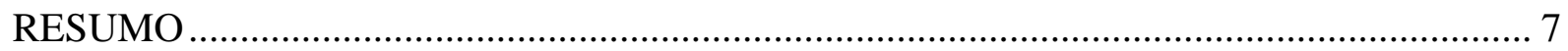

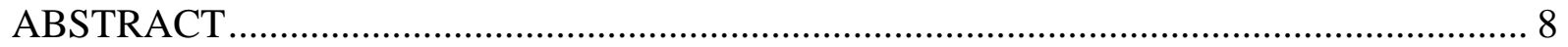

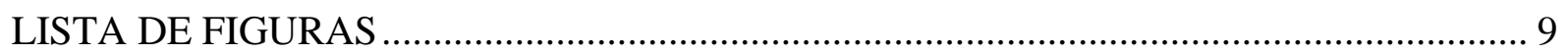

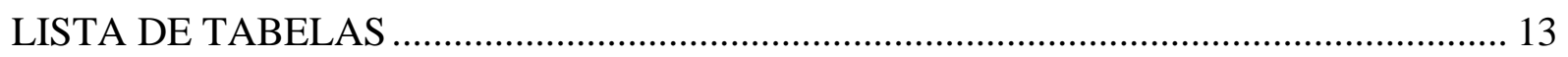

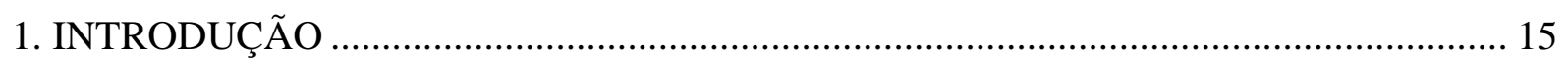

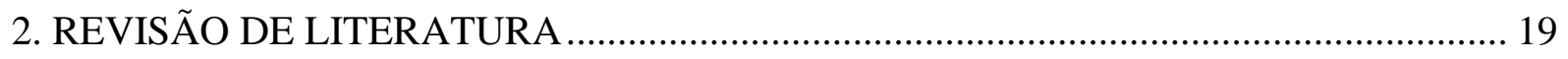

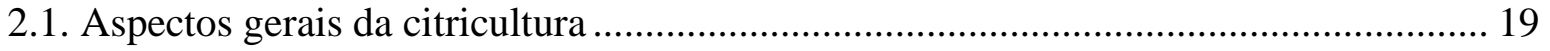

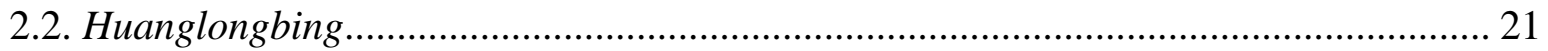

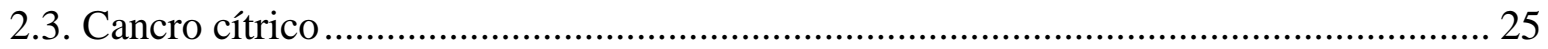

2.4. Transformação genética para resistência a doenças .................................................. 27

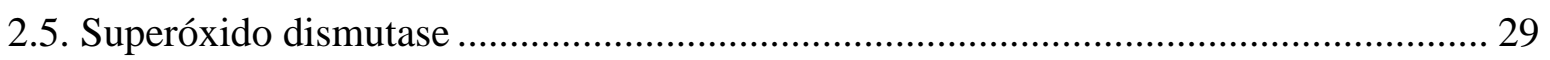

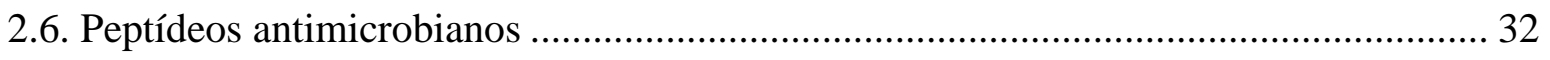

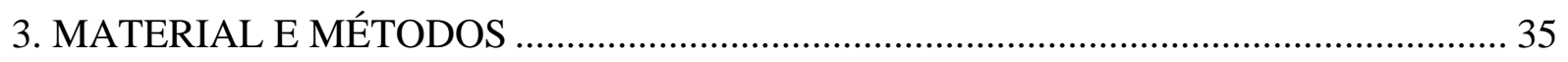

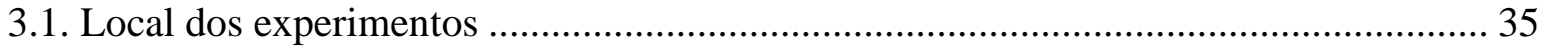

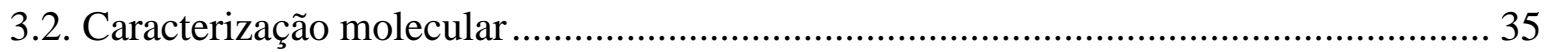

3.3. Multiplicação vegetativa das plantas transgênicas e não transgênicas ........................ 38

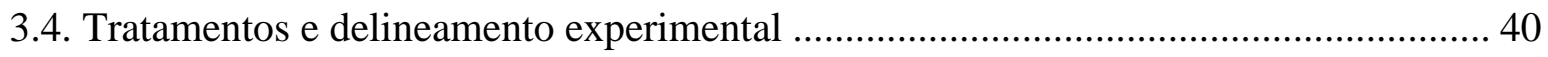

3.5. Reação de plantas transgênicas de laranja doce à infecção por Candidatus Liberibacter

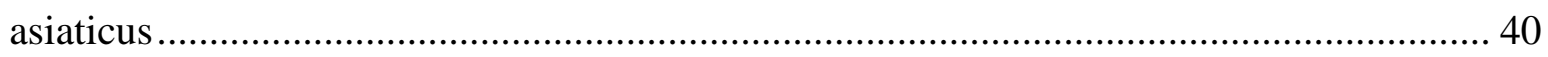

3.6. Reação de plantas transgênicas de laranja doce à infecção por Xanthomonas citri subsp.

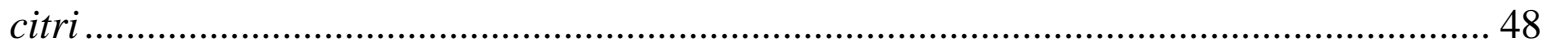

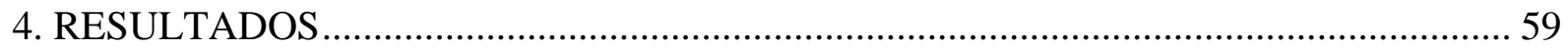

4.1. Caracterização molecular dos eventos transgênicos expressando o gene $\operatorname{csdl}$............59

4.2. Reação de plantas transgênicas de laranja doce à infecção por CLas ........................... 60

4.3. Reação de plantas transgênicas de laranja doce à infecção por $X c c$............................ 72

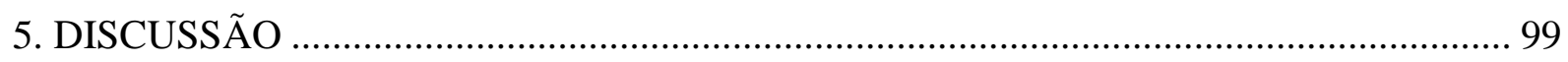

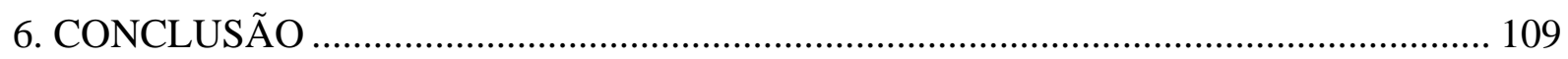

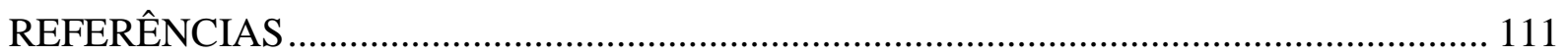




\title{
RESUMO
}

\section{Desafio de laranjeiras doces geneticamente modificadas à infecção por Candidatus}

\author{
Liberibacter asiaticus e Xanthomonas citri subsp. citri
}

\begin{abstract}
O Brasil é o maior produtor mundial de laranja doce, assim como o maior exportador de suco concentrado. Entretanto, o setor citrícola apresenta algumas dificuldades no processo produtivo atribuídas, principalmente, a problemas fitossanitários, com ênfase para doenças bacterianas, a exemplo do huanglongbing (HLB) e do cancro cítrico. O HLB é considerado uma das doenças mais destrutivas que a citricultura já enfrentou, sendo agravada pela ausência de medidas curativas e de cultivares de citros resistentes. Da mesma forma, o cancro cítrico é uma importante doença, a qual tem registrado um aumento considerável de sua incidência nos pomares cítricos nos anos recentes. Nesse cenário, a produção de plantas transgênicas pode ser uma solução eficaz na busca de cultivares resistentes com o uso de diversas estratégias, tais como a expressão de genes que codificam peptídeos antimicrobianos e de genes diferencialmente expressos em plantas resistentes inoculadas com diferentes patógenos. Diante disso, o objetivo deste trabalho foi avaliar a reação de plantas de laranja 'Hamlin' (Citrus sinensis L. Osbeck) transformadas com o gene que codifica o peptídeo antimicrobiano e sintético $d 4 e 1$, dirigido pelo promotor $35 \mathrm{~S}$ e plantas de laranja 'Hamlin' transformadas com o gene que codifica a superóxido dismutase do cobre e do zinco ( $c s d 1)$, isolado de Poncirus trifoliata e dirigido pelo promotor Ubiquitina 10, desafiando-as contra Candidatus Liberibacter asiaticus e Xanthomonas citri subsp. citri. As plantas de laranja 'Hamlin' foram propagadas, por enxertia, em porta-enxertos de limão 'Cravo' (Citrus limonia Osbeck), e então inoculadas com borbulhões infectados com $C$ Las, ou inoculadas, por aspersão e por ferimentos, com suspensão de $X c c$. A presença e concentração de $C$ Las foram determinadas nos tecidos foliares, por qPCR, seis, 12 e 18 meses após a inoculação (m.a.i.). O acúmulo de peróxido de hidrogênio, as atividades de enzimas antioxidantes e a detecção de calose foram avaliadas em eventos transgênicos de laranjeira doce após as inoculações dos patógenos. Cinco eventos transgênicos que expressam o gene $c s d l$ e outro, expressando o gene $d 4 e l$, exibiram populações reduzidas de $C$ Las quando comparados com plantas não transgênicas, e não mostraram sintomas visíveis de HLB, seis m.a.i. de $C$ Las. A incidência e severidade de cancro cítrico foram reduzidas em alguns eventos transgênicos, exibindo populações de Xcc significativamente inferiores quando comparadas com plantas não transgênicas. Os eventos transgênicos que registraram maiores atividades isoenzimáticas de SOD também exibiram maiores acúmulos de peróxido de hidrogênio nos tecidos foliares, após a inoculação com Xcc. A análise de epifluorescência mostrou alta deposição de calose nos elementos de tubo crivado nos tecidos foliares de alguns eventos transgênicos. Esses resultados sugerem que a formação da calose pode ser uma importante resposta de defesa aos estresses bióticos, resultando em menores populações de $C$ Las e $X c c$.
\end{abstract}

Palavras-chave: Citrus sinensis, Transformação genética, Resistência a doenças, Bactérias 


\title{
ABSTRACT \\ Challenge of genetically modified sweet orange plants to infection by Candidatus
}

\author{
Liberibacter asiaticus and Xanthomonas citri subsp. citri
}

\begin{abstract}
Brazil is the world's largest producer of sweet orange, as well as the largest exporter of concentrated juice. However, the citrus sector has some difficulties in the production process, mainly attributed to phytosanitary problems, with emphasis on bacterial diseases, such as huanglongbing (HLB) and citrus canker. HLB is of the most destructive diseases that the citrus industry has ever faced, being aggravated by the absence of curative measures and resistant citrus cultivars. Likewise, citrus canker is an important disease, which has registered a considerable increase in its incidence in citrus groves in the recent years. In this scenario, the production of transgenic plants can be an effective solution in the search for resistant cultivars with the use of several strategies, such as the expression of genes that encode antimicrobial peptides and of genes differentially expressed in resistant plants inoculated with different pathogens. Therefore, the objective of this work was to evaluate the reaction of 'Hamlin' sweet orange plants (Citrus sinensis L. Osbeck) transformed with the gene that encodes the $d 4 e 1$ antimicrobial and synthetic peptide, directed by the $35 \mathrm{~S}$ promoter and 'Hamlin' sweet orange plants transformed with the gene expressing a copper and zinc superoxide dismutase ( $c s d l)$, isolated from Poncirus trifoliata and directed by Ubiquitin 10 promoter, challenging them against Candidatus Liberibacter asiaticus and Xanthomonas citri subsp. citri. The 'Hamlin' sweet orange plants were propagated by grafting on Rangpur lime rootstocks (Citrus limonia Osbeck), and then graft-inoculated with CLas contaminated axillary buds, or inoculated, by spraying and wounding, with a Xcc suspension. The presence and concentration of CLas were determined in the leaf tissues, by qPCR, six, 12, and 18 months after inoculation (m.a.i.). The hydrogen peroxide accumulation, activities of antioxidant enzymes, and detection of callose were evaluated in transgenic sweet orange events after the inoculation of the pathogens. Five transgenic events expressing $c s d l$ and another, expressing $d 4 e l$ gene, exhibited reduced $C$ las populations when compared with non-transgenic plants, and showed no visible HLB symptoms six m.a.i.. The incidence and severity of citrus canker have been reduced in some transgenic events, showing significantly lower Xcc populations when compared to non-transgenic plants. The transgenic events that registered greater SOD isoenzymatic activities also exhibited greater hydrogen peroxide accumulations in the leaf tissues, after Xcc inoculation. Epifluorescence analysis showed a high amount of callose deposition in the sieved tube elements of the leaf tissues in some of the transgenic lines. These results suggest that the formation of callose may be an important defense response these biotic stresses, resulting in lower CLas and Xcc population.
\end{abstract}

Keywords: Citrus sinensis, Genetic transformation, Disease resistance, Bacteria 


\section{LISTA DE FIGURAS}

Figura 1. Componentes envolvidos na geração de ROS e seus efeitos sobre o patógeno ou sobre a ativação dos mecanismos de defesa das plantas

Figura 2. Representação esquemática do T-DNA (5.693 pb) do vetor de transformação pCAMBIA2301-csdl, contendo o gene csdl, o gene de seleção nptII (neomicina fosfotransferase II) e o gene reporter uidA. 35S-P: Promotor 35S; 35S-T: Terminador 35S; UBI10: promotor Ubiquitina 10; OCS: terminador octopina sintase; NOS-T: terminador nopalina sintetase; LB: borda esquerda; RB: borda direita

Figura 3. Representação esquemática do T-DNA do vetor de transformação pCAMBIA2201$d 4 e 1$, contendo o gene $d 4 e 1$ e o gene de seleção nptII (neomicina fosfotransferase II). 35S-P: Promotor 35S; 35S-T: terminador 35S; NOS-T: terminador nopalina sintetase; LB: borda esquerda; RB: borda direita

Figura 4. Multiplicação vegetativa de plantas transgênicas de laranja 'Hamlin'. (A) Plantas de limão 'Cravo' recém-enxertadas. (B) Retirada de fitilhos 20 dias após a enxertia. (C) Desenvolvimento do clone transgênico 55 dias após a enxertia da borbulha, em Piracicaba, SP

Figura 5. Folha de laranja 'Hamlin' não inoculada com CLas. (A) Destaque para as replicatas (linhas) de mapeamento onde foram realizadas as análises de distribuição espacial de nutrientes. (B) Folhas secas de laranja 'Hamlin' com HLB, 18 meses após a inoculação. (C e D) Espectrômetro de fluorescência de raios X com feixe micrométrico $(\mu-X R F$, Orbis PC, EDAX,

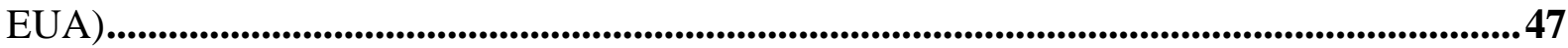

Figura 6. Expressão relativa do gene $c s d 1$ em relação aos genes de referência UBC21 e DIM1 em plantas de laranja 'Hamlin', expressando a construção gênica pCAMBIA2301-Ptcsd1. Os resultados obtidos foram comparados com o nível de transcrição da planta não transgênica (Testemunha - T1), utilizada como calibrador. *Difere significativamente em relação à média de (T1), pelo teste de Dunnett $(P<0,05)$. As barras indicam o desvio padrão das médias ........59

Figura 7. Sintomas foliares de HLB em plantas de laranja 'Hamlin', seis meses após a inoculação. (A) Amarelecimento foliar e mosqueado observados em plantas não transgênicas (T1). (B) Plantas transgênicas de laranja 'Hamlin' (evento TG3-16, gene csd1) sem sintomas de HLB. (C) Sintomas normalmente associados a deficiências nutricionais de manganês ou zinco em folhas de laranja 'Hamlin' não transgênica (T1). (D) Sintomas leves de HLB em folhas de laranja 'Hamlin' transgênica (evento TG4-9, gene $c s d 1$ ), em Piracicaba, SP 61

Figura 8. Deposição de calose em segmentos foliares de laranja 'Hamlin'. Seções longitudinais (A, B, C, D, E, F, J, K, L); seções transversais (G, H, I, M, N, O); microscopia de luz (A, B, C, $\mathrm{D}, \mathrm{G}, \mathrm{J}, \mathrm{M})$; microscopia de epifluorescência após o método de coloração com azul de anilina (E, F, H, I, K, L, N, O). Plantas não inoculadas com CLas (A, B, C). Plantas não transgênicas (T1), inoculadas com $C$ Las (D, E, F, G, H, I). Plantas transgênicas (evento TG4-2, gene csdl), inoculadas com CLas (J, K, L, M, N, O). A deposição de calose (setas brancas) ocorreu em 
todas as plantas inoculadas, porém em maior evidência nas áreas de infecções do evento transgênico. fl: floema; xi: xilema; *(em vermelho), pontos de calose

Figura 9. Análise in vivo da distribuição espacial de macronutrientes (A, B, C, D) e micronutrientes $(E, F, G, H)$ através da espectroscopia de fluorescência de raios $X(\mu-X R F)$ em folhas de laranjeiras doces sem (I) e com HLB (K). Análise química foliar de macronutrientes de laranjeiras doces $(\mathrm{J})$. Todas as intensidades elementares de XRF foram normalizadas pelo espalhamento ROI Compton (COMPTON, 1923). Replicata 1 (L1), replicata 2 (L2)............ 71

Figura 10. Incidência de cancro cítrico nas plantas transgênicas medida pela porcentagem de folhas com sintomas, comparada às plantas não transgênicas, 35 DAI, no primeiro experimento. Os valores apresentados são percentuais relativos à T1 e (*) indica diferença significativa pelo teste de Dunnett $(P<0,05)$. Cada coluna representa a média de 12 plantas. As barras indicam desvio padrão das médias.

Figura 11. Severidade de cancro cítrico nas plantas transgênicas medida pela porcentagem de área foliar com lesão, comparada às plantas não transgênicas, 35 DAI, no primeiro experimento. Os valores apresentados são percentuais relativos à T1 e (*) indica diferença significativa pelo teste de Dunnett $(P<0,05)$. Cada coluna representa a média de 12 plantas. As barras indicam desvio padrão das médias.

Figura 12. Incidência de cancro cítrico nas plantas transgênicas medida pela porcentagem de folhas com sintomas, comparada às plantas não transgênicas, 35 DAI, no segundo experimento. Os valores apresentados são percentuais relativos à T1 e $\left(^{*}\right)$ indica diferença significativa pelo teste de Dunnett $(P<0,05)$. Cada coluna representa a média de 12 plantas. As barras indicam desvio padrão das médias.

Figura 13. Severidade de cancro cítrico nas plantas transgênicas medida pela porcentagem de área foliar com lesão, comparada às plantas não transgênicas, 35 DAI, no segundo experimento. Os valores apresentados são percentuais relativos à T1 e (*) indica diferença significativa pelo teste de Dunnett $(P<0,05)$. Cada coluna representa a média de 12 plantas. As barras indicam desvio padrão das médias.

Figura 14. Incidência de cancro cítrico nas plantas transgênicas medida pela porcentagem de folhas com sintomas, comparada às plantas não transgênicas, 35 DAI, no terceiro experimento. Os valores apresentados são percentuais relativos à T1 e (*) indica diferença significativa pelo teste de Dunnett $(P<0,05)$. Cada coluna representa a média de 12 plantas. As barras indicam desvio padrão das médias.

Figura 15. Severidade de cancro cítrico nas plantas transgênicas medida pela porcentagem de área foliar com lesão, comparada às plantas não transgênicas, 35 DAI, no terceiro experimento. Os valores apresentados são percentuais relativos à T1 e (*) indica diferença significativa pelo teste de Dunnett $(P<0,05)$. As barras indicam desvio padrão das médias .................................... 76

Figura 16. Severidade de cancro cítrico em folhas de laranja 'Hamlin', 35 DAI. (A) Folhas do evento transgênico (TG4-28) mais suscetível à infecção por Xcc. (B) Folhas do evento transgênico (TG4-9) menos suscetível. (C) Folhas de plantas não transgênicas. Ilustração representativa dos resultados médios obtidos dos três experimentos independentes 
Figura 17. Quantificação da população bacteriana em lesões de folhas de laranja 'Hamlin' transgênicas e não transgênicas, inoculadas com $X c c$, em três experimentos independentes (I, II, III). As barras representam o desvio padrão das médias. Média de três repetições biológicas Data de inoculação: $1^{\circ}$ exp. (10/05/2018); $2^{\circ}$ exp. (10/08/2018); $3^{\circ}$ exp. (11/02/2019) ...........80

Figura 18. Área média das lesões de cancro cítrico em folhas de laranja 'Hamlin' transgênicas e não transgênicas, inoculadas com $X c c$, no primeiro experimento, 35 DAI. *Difere significativamente em relação à média das plantas não transgênicas (T1), pelo teste de Dunnett $(P<0,05)$. As barras representam o desvio padrão das médias

Figura 19. Sintomas de cancro cítrico em folhas de laranja 'Hamlin' não transgênicas. (A e B) Formação de pústulas na face abaxial da folha, 16 DAI. (C e D) Seção transversal da lesão anterior, com destaque para a detecção da Xcc_GFP através da microscopia de epifluorescência. Nota-se o rompimento da epiderme. (E e F) Seção transversal do tecido foliar com destaque para a hipertrofia e hiperplasia do mesofilo. A seta indica a área necrosada, 30 DAI. (G e H) Detalhes da penetração da bactéria, formação de células hipertrofiadas e degradação da parede celular, corada com Calcofluor White. pp: parênquima paliçádico, pl: parênquima lacunoso, ei: espaço intercelular

Figura 20. Presença de biofilme de Xcc_GFP na superfície abaxial das folhas do evento-elite transgênico (TG4-9), 30 DAI. (A e B) Setas indicam a presença de bactéria. (C) Detalhe da região em destaque na foto anterior, observada através da microscopia de epifluorescência. $(\mathrm{D}$, E, F) Seção transversal do tecido foliar (biofilme de Xcc), com o início da penetração e colonização da bactéria nos espaços intercelulares. Nota-se a hipertrofia (hpt) e hiperplasia (hpp) das células do parênquima lacunoso na tentativa de retardar a colonização no tecido foliar. (G, H, I) Processo de penetração, degradação da parede celular e perda do espaço extracelular livre. pp: parênquima paliçádico, pl: parênquima lacunoso

Figura 21. Deposição de calose em tecidos foliares de laranja 'Hamlin', 24, 48 e 72 horas após a inoculação (h.a.i.) com Xcc, por ferimento (A, B, C). Microscopia de epifluorescência após o método de coloração com azul de anilina, em folhas de plantas não transgênicas (D, E, F). Plantas transgênicas, evento TG4-9 (G, H, I). A deposição de calose (setas brancas) ocorreu em todas as plantas inoculadas, porém em maior evidencia na região de infecção do evento transgênico analisado. gl: glândula lisígena de óleo. . .88

Figura 22. Expressão relativa do gene $c s d l$ em plantas transgênicas e não transgênicas de laranja 'Hamlin', 0, 24, 48, 72 h.a.i. de Xcc. * Difere significativamente pelo teste de Dunnett $(\mathrm{P}<0,05)$ em relação ao nível de transcrição médio (em três replicatas biológicas) de cada evento, comparado com as plantas não transgênicas (T1), no tempo 0h. As barras indicam o desvio padrão das médias $(\mathrm{n}=3)$.

Figura 23. Concentração de malondialdeído (MDA) nos tecidos foliares de plantas transgênicas e não transgênicas de laranja 'Hamlin' inoculadas por $X c c$. *Difere significativamente em relação à média das plantas não transgênicas $(\mathrm{T} 1)$, pelo teste de Dunnett $(P<0,05)$, em cada período avaliado. Os resultados representam a média de três repetições biológicas $(n=3)$ e as barras indicam o desvio padrão das médias 
Figura 24. Quantificação de peróxido de hidrogênio $\left(\mathrm{H}_{2} \mathrm{O}_{2}\right)$ nos tecidos foliares de plantas transgênicas e não transgênicas de laranja 'Hamlin' inoculadas por Xcc. *Difere significativamente em relação à média das plantas não transgênicas (T1), pelo teste de Dunnett $(P<0,05)$, em cada período avaliado. Os resultados representam a média de três repetições biológicas $(n=3)$ e as barras indicam o desvio padrão das médias.

Figura 25. Localização de peróxido de hidrogênio $\left(\mathrm{H}_{2} \mathrm{O}_{2}\right)$ nos tecidos foliares de plantas transgênicas e não transgênicas de laranja 'Hamlin' 12, 24 e 48 h.a.i. com Xcc. Área corada pelo reagente $\mathrm{DAB}$ em folhas de plantas não transgênicas $(\mathrm{A}, \mathrm{B}, \mathrm{C})$ e folhas do evento transgênico TG4-9 (D, E, F). Quantificação do diâmetro e área dos locais de acúmulo de $\mathrm{H}_{2} \mathrm{O}_{2}$. *Difere significativamente em relação à média das plantas não transgênicas (T1), pelo teste de Dunnett $(P<0,05)$, em cada período avaliado. As barras representam o desvio padrão das médias $(\mathrm{n}=20)$. 93

Figura 26. Atividade de SOD nos tecidos foliares de plantas transgênicas e não transgênicas de laranja 'Hamlin' inoculadas por $X c c$. *Difere significativamente em relação à média das plantas não transgênicas (T1), pelo teste de Dunnett $(P<0,05)$, em cada período avaliado. Os resultados representam a média de três repetições biológicas $(n=3)$ e as barras indicam o desvio padrão das médias

Figura 27. Caracterização de isoformas de SOD em PAGE não-desnaturante em tecidos foliares de plantas transgênicas e não transgênicas de laranja 'Hamlin' inoculadas por Xcc. (A) Amostras de folhas de plantas não transgênicas (T1) comparadas com plantas transgênicas (TG4-4) que expressam o gene $c s d 1$. Destaque para a formação de duas bandas correspondentes às isoformas Mn-SOD e Cu/Zn-SOD. (B) Amostras de folhas de plantas não transgênicas (T1) comparadas com plantas transgênicas (HS9) que expressam o gene $d 4 e 1$. Destaque para a formação de apenas uma banda correspondente à isoforma Mn-SOD. Mn-SOD é resistente a ambos os inibidores. Fe-SOD é resistente ao KCN e inibida por $\mathrm{H}_{2} \mathrm{O}_{2}$. Cu/Zn-SOD é inibida por ambos os inibidores. 95

Figura 28. Atividade de catalase nos tecidos foliares de plantas transgênicas e não transgênicas de laranja 'Hamlin' inoculadas por Xcc. Os resultados representam a média de três repetições biológicas $(n=3)$ e as barras indicam o desvio padrão das médias. 96

Figura 29. Atividade de glutationa peroxidase nos tecidos foliares de plantas transgênicas e não transgênicas de laranja 'Hamlin' inoculadas por Xcc. Os resultados representam a média de três repetições biológicas $(n=3)$ e as barras indicam o desvio padrão das médias

Figura 30. Atividade antimicrobiana in vitro do extrato proteico de plantas transgênicas de laranja 'Hamlin', expressando o gene $d 4 e$, e de plantas não transgênicas de laranja 'Hamlin' após a incubação com suspensões de Xcc. *Difere significativamente em relação à média da planta não transgênica (T1), pelo teste de Dunnett $(P<0,05)$. Os resultados representam a média de três repetições biológicas $(n=3)$ e as barras indicam o desvio padrão das médias 


\section{LISTA DE TABELAS}

Tabela 1. Sequência de primers utilizados para a amplificação dos genes de referência UBC21 e DIM1, e do gene $c s d 1$ na análise de RT-qPCR .....................................................................38

Tabela 2. Amplificação de DNA por qPCR e número de cópias (NC) da sequência 16S rDNA bacteriano em plantas transgênicas e não transgênicas de laranja 'Hamlin' infectadas por CLas

Tabela 3. Determinação dos valores médios de matéria seca† (expressa em gramas) da parte aérea e do sistema radicular de plantas transgênicas e não transgênicas de laranja 'Hamlin', 18 meses após a inoculação de $C$ Las, em Piracicaba, SP.

Tabela 4. Análise química foliar de macronutrientes $\left(\mathrm{g} \mathrm{kg}^{-1}\right)$ em plantas transgênicas e não transgênicas de laranja 'Hamlin', avaliadas seis e 18 meses após a inoculação de CLas, em Piracicaba, SP

Tabela 5. Aumento médio $†$ diário de incidência e severidade de cancro cítrico da área abaixo da curva do progresso da doença (AACPD) em função do tempo, em folhas de laranja 'Hamlin' transgênicas e não transgênicas, obtido em três experimentos independentes, em Piracicaba, SP

Tabela 6. Número de lesões $\dagger$ de cancro cítrico formadas após inoculações, por ferimentos, em folhas de laranja 'Hamlin' transgênicas e não transgênicas, em Piracicaba, SP .81 


\section{INTRODUÇÃO}

A laranjeira doce (Citrus sinensis L. Osbeck) é a principal espécie cítrica cultivada no Brasil. Pertencente à família Rutaceae é originária da Ásia, tendo as regiões do nordeste da Índia e norte de Burma como centro de origem (SHARMA et al., 2004). O Brasil é o maior produtor mundial de laranja doce, com uma área colhida de 589.610 hectares e uma produção de 17,07 milhões de toneladas, seguido da China, Índia, Estados Unidos da América e México. O estado de São Paulo é o maior produtor brasileiro de laranja, com 13.256.246 toneladas, correspondendo a 77,6\% da produção nacional (INSTITUTO BRASILEIRO DE GEOGRAFIA E ESTATÍSTICA - IBGE, 2020).

Embora exista uma excelente adaptação das laranjeiras às condições edafoclimáticas brasileiras, com notório destaque para a produção de frutos e relevância no cenário econômico nacional, o setor citrícola enfrenta inúmeros problemas relacionados à incidência de doenças causadas por vírus, fungos e bactérias, que ocorrem, principalmente, devido à estreita variabilidade genética das espécies cítricas, ausência de cultivares resistentes a esses patógenos, além da continuidade temporal e espacial de produção (MACHADO; CRISTOFANI-YALY; BASTIANEL, 2011).

As doenças causadas por bactérias são as responsáveis pelos maiores prejuízos na citricultura, afetando significativamente a produção, a longevidade dos pomares e a qualidade dos frutos (NEVES et al., 2010). As principais doenças bacterianas presentes nos cultivos comerciais são o cancro cítrico causado por Xanthomonas citri subsp. citri (SCHAAD et al., 2006) e o huanglongbing (HLB ou greening) que está associado a espécies de Candidatus Liberibacter spp. (HALBERT; MANJUNATH, 2005; TEIXEIRA et al., 2005; COLETTAFILHO et al., 2004). As manifestações dessas doenças são consideradas graves ameaças às diversas regiões produtoras de citros, causando complexas e severas perturbações no metabolismo, anatomia e fisiologia das plantas (GMITTER, 2016).

O HLB é a doença mais importante e destrutiva da citricultura mundial, agravada principalmente pela ausência de medidas curativas e de cultivares resistentes ao patógeno (GOTTWALD et al., 2007; BOVÉ, 2006). Transmitidas por insetos vetores, o psilídeo-asiático (Diaphorina citri Kuwayama) e o psilídeo-africano-dos-citros (Trioza erytreae Del Guercio), as bactérias restritas de floema associadas ao HLB são três espécies pertencentes ao gênero Candidatus Liberibacter: $C$. L asiaticus (CLas), $C . \mathrm{L}$ americanus (CLam) e $C . \mathrm{L}$ africanus 
(CLaf) (DA GRAÇA et al., 2016). No Brasil, a doença foi constatada pela primeira vez em 2004, apresentando sintomas característicos nas plantas, tais como o amarelecimento das folhas, com áreas verdes que adquirem aspectos de manchas irregulares e mosqueadas, além de má formação e quedas prematuras de frutos (TEIXEIRA et al., 2005; COLETTA-FILHO et al., 2004).

Da mesma forma, o cancro cítrico é uma doença presente nas principais regiões produtoras de citros do mundo, incluindo o estado de São Paulo, provocando danos e perdas relevantes (BELASQUE JR, 2005). Identificada no Brasil pela primeira vez em 1957, as bactérias Xanthomonas citri subsp. citri infectam os tecidos das plantas e são capazes de induzir sintomas em, praticamente, todas as espécies de Citrus e de outros gêneros da família Rutaceae, causando desfolha, queda prematura de frutos e depreciação da produção (GOTTWALD et al., 1993).

As principais medidas de controle dessas doenças consistem na utilização de mudas sadias de viveiros devidamente certificados, exclusão da entrada de inóculo externo, erradicação de plantas sintomáticas (GOTTWALD et al., 2001) e eliminação de insetos vetores no caso do HLB. Diante deste cenário, pacotes tecnológicos podem ser um importante reforço na busca por cultivares resistentes às doenças, a fim de evitar maiores prejuízos. Desta forma, a transformação genética de plantas, uma das estratégias que compõem esse pacote, torna-se uma alternativa para a obtenção de plantas transgênicas, com o uso de genótipos desejáveis que estimulem a defesa das plantas, tornando-as resistentes ou tolerantes às principais doenças bacterianas de citros.

Diversos genes podem ser utilizados na transformação genética de plantas cítricas visando resistência a patógenos. Existem genes que podem codificar proteínas relacionadas à patogênese, genes que estimulam o sistema de defesa das plantas, genes maiores de resistência, genes que codificam moléculas elicitoras de respostas de defesa nas plantas, genes que codificam peptídeos antimicrobianos e genes do próprio genoma do patógeno (MOURÃO FILHO; STIPP; MENDES, 2010).

Dentre as estratégias mais promissoras para a produção de transgênicos resistentes a doenças, destacam-se o uso de genes que codificam peptídeos antimicrobianos, a exemplo do $d 4 e 1$, e também de genes diferencialmente expressos em plantas tolerantes que codificam a superóxido dismutase do cobre e do zinco, como o $c s d l$. O gene sintético $d 4$ el é derivado de 
uma cecropina, peptídeo com atividades antimicrobianas comprovadas in vitro (STOVER et al., 2013) e in vivo no controle de fitopatógenos de culturas como tabaco (CARY et al., 2000), híbridos de álamos (Populus tremula L. x Populus alba L.) (MENTAG et al., 2003) e algodão (RAJASEKARAN et al., 2005). As enzimas do grupo superóxido dismutase, em especial as de cobre e zinco (Cu-Zn SODs), são encontradas naturalmente nos cloroplastos, no citosol e nos espaços extracelulares das plantas, estando relacionadas com a proteção e defesa destas contra o estresse oxidativo de origem biótica ou abiótica envolvido na patofisiologia de grande número de doenças (ALBRECHT; BOWMAN, 2012; ELSTNER, 1991).

Desta forma, a obtenção de plantas transgênicas de cultivares de laranja doce contendo os genes $d 4 e l$ ou $c s d l$ pode ser uma alternativa viável ao controle das bactérias do HLB e do cancro cítrico, uma vez que as proteínas codificadas por esses genes atuam como potentes peptídeos antimicrobianos e antioxidantes, respectivamente, que agem contra diversos patógenos (DUTT et al., 2012; BAFFANA et al., 2011). Diante disso, o objetivo deste trabalho foi avaliar a reação de plantas de laranja 'Hamlin' (Citrus sinensis L. Osbeck) transformadas com o gene $d 4 e 1$, dirigido pelo promotor $35 \mathrm{~S}$ e de plantas de laranja 'Hamlin' transformadas com o gene csdl, isolado de Poncirus trifoliata e dirigido pelo promotor Ubiquitina, desafiando-as contra Candidatus Liberibacter asiaticus e Xanthomonas citri subsp. citri, agentes causais do HLB e do cancro cítrico. 


\section{REVISÃO DE LITERATURA}

\subsection{Aspectos gerais da citricultura}

A família botânica Rutaceae engloba mais de 1900 espécies, agrupadas em 158 gêneros diferentes, na qual estão incluídas as plantas cítricas (MABBERLEY, 2008). Esta família apresenta grande complexidade em relação a sua filogenia e classificação taxonômica, marcada pelas particularidades da biologia reprodutiva e pelo seu amplo histórico de cultivo das espécies verdadeiras e de seus correspondentes híbridos (GROPPO et al., 2008). As plantas cítricas englobam os gêneros Citrus, Eremocitrus, Clymenia, Microcitrus, Fortunella e Poncirus, agrupadas na subfamília Aurantioideae, tribo Citreae e subtribo Citrinae (ARAÚJO; ROQUE, 2005). O gênero Citrus, por sua vez, é o de maior importância econômica da família, possuindo diversas espécies cultivadas destacando-se as laranjas doces (Citrus sinensis L. Osbeck), as tangerinas (Citrus reticulata Blanco), as limas ácidas [Citrus aurantifolia (Christm.) Swing e Citrus latifolia (Yu. Tanaka)], os limões (Citrus limon), os pomelos (Citrus paradisi), as cidras (Citrus medica), as toranjas (Citrus grandis), e outros híbridos naturais (CHAPOT, 1975).

As plantas cítricas surgiram entre 20 e 30 milhões de anos atrás tendo seu centro de origem as extensas áreas que vão do nordeste da Índia, em direção às Filipinas e do centro-norte chinês (Himalaia), ao sul, em direção à Indonésia ou à Austrália (SHARMA et al., 2004). Devido à sua excelente adaptação climática, o cultivo dos citros foi possível em diversas regiões, expandindo-se além da Ásia, especialmente para a Europa e África e, no século XVI, para as Américas (DAVIES; ALBRIGO, 1994).

As principais áreas comerciais de citros situam-se em regiões tropicais e subtropicais, compreendidas em uma faixa entre as latitudes $44^{\circ}$ Norte e $41^{\circ}$ Sul, onde se encontram as melhores condições edafoclimáticas para o seu desenvolvimento (DAVIES; ALBRIGO, 1994). A produção mundial de frutas cítricas em 2018 foi de 146,5 milhões de toneladas, sendo as mais produzidas e consumidas no mundo. A China é o maior produtor mundial de citros, com 39,3 milhões de toneladas, seguida pelo Brasil com 19,5 milhões de toneladas, Índia com 11,4 milhões de toneladas e Estados Unidos da América com 7 milhões de toneladas (FAO, 2020). O Brasil se destaca como o maior produtor mundial de laranjas doces com 17,07 milhões de toneladas, seguido pela China, Índia, Estados Unidos da América e México (IBGE, 2020; FAO, 2020). Além de recordista na produção de laranjas, o Brasil também é o maior produtor e 
exportador de suco de laranja concentrado, sendo responsável por 61\% (1.078.517 toneladas em equivalente concentrado) de toda a demanda mundial, destinando esse produto, principalmente, para os países da comunidade europeia e Estados Unidos da América (CitrusBR, 2020; NEVES et al., 2010).

O estado de São Paulo é o maior produtor brasileiro de laranja, com produção de 13,2 milhões de toneladas, distribuídas em uma área de 377.182 hectares, seguido pelos estados de Minas Gerais com 989.032 toneladas, Paraná com 694.424 toneladas e Bahia com 574.211 toneladas (IBGE, 2020). A principal região citrícola brasileira, chamada de cinturão citrícola, é compreendida pelos estados de São Paulo e o Triângulo/Sudoeste Mineiro, que concentram $83 \%$ das laranjas produzidas no país, com mais de 174 milhões de árvores produtivas distribuídas, principalmente, entre as cultivares Pera Rio, Valência, Hamlin, Natal, Westin e Valência Folha Murcha (FUNDECITRUS, 2020). Desta forma, a citricultura nacional está fortemente concentrada e limitada a uma baixa diversidade de cultivares, tornando-as vulneráveis aos constantes ataques de pragas e doenças que afetam a produtividade dos pomares (NEVES et al., 2012).

Diversas doenças afetaram a citricultura brasileira ao longo da história, proporcionando modificações no sistema de cultivo, principalmente, em relação ao estímulo da obtenção de variedades porta-enxertos resistentes, assim como, na busca pelo desenvolvimento de plantas geneticamente modificadas que visam o combate das doenças do setor citrícola. As doenças mais relevantes que afetam a citricultura paulista são causadas por vírus, como a leprose Citrus leprosis virus C (CiLV-C), por fungos, como a pinta-preta (Phyllosticta citricarpa) e a podridão floral (complexo Colletotrichum acutatum) e por bactérias como a clorose variegada dos citros (CVC - Xyllela fastidiosa), o huanglongbing (HLB - doença associada a duas bactérias de Candidatus Liberibacter) e o cancro cítrico (Xanthomonas citri subsp. citri).

O huanglongbing e o cancro cítrico estão entre as doenças mais devastadoras da citricultura paulista, que colocam em risco esta importante atividade econômica. No estado de São Paulo, nos últimos 15 anos, houve a erradicação de mais de 55 milhões de plantas em função dessas doenças, ocasionadas, principalmente, pela grande capacidade de disseminação dos patógenos e pela ausência de medidas curativas de controle e de resistência genética (FUNDECITRUS, 2020; BEHLAU; BELASQUE JR, 2014). 


\subsection{Huanglongbing}

O huanglongbing (HLB ou greening) é a doença mais destrutiva da citricultura mundial, afetando todas as variedades comerciais de citros (GOTTWALD, 2010). Essa doença foi detectada pela primeira vez no sul da China no final do século XIX e está presente há décadas nos continentes asiático e africano, distribuída em mais de 40 países do mundo (BOVÉ, 2006). A primeira detecção da doença no continente americano foi em 2004, no Brasil, na região de Araraquara-SP, e, posteriormente, espalhou-se para novas regiões citrícolas do país, sendo que, atualmente, 20,87\% das plantas de citros situadas no parque citrícola de São Paulo e Minas Gerais estão contaminadas pelo HLB (FUNDECITRUS, 2020; BELASQUE JR et al., 2010).

O HLB é uma doença associada à bactéria Candidatus Liberibacter spp., Gramnegativa, pertencente ao grupo das alfa-proteobactérias e à família Rhizobiaceae, cujo postulado de Koch ainda não foi concluído devido à dificuldade de seu cultivo, recebendo assim a denominação genérica de Candidatus (WANG; TRIVEDI, 2013). Atualmente, três espécies de bactérias restritas aos tecidos floemáticos e associadas a essa doença, conhecidas como CLas, CLaf e CLam foram identificadas com base na sequência 16S rDNA do genoma do patógeno (BOVÉ, 2006; JAGOUEIX; BOVÉ; GARNIER, 1994).

Endêmica do continente asiático, CLas é a espécie mais disseminada no mundo, provavelmente em função de sua menor sensibilidade a altas temperaturas e maior eficiência de transmissão pelo vetor, podendo ser encontrada também nos países das Américas do Sul, Central e do Norte e associada às epidemias de HLB (LOPES et al., 2009; MARTÍNEZ et al., 2009). CLam foi detectada somente no Brasil e CLaf está presente no continente africano (BOVÉ, 2006). Além dessas espécies de bactérias, em 2007, foi detectada a presença de fitoplasmas, bactérias sem a parede celular externa, em plantas com sintomas de HLB em pomares comerciais de citros localizados no norte e noroeste do estado de São Paulo (TEIXEIRA et al., 2008). Em 2009, outro fitoplasma foi associado ao HLB em amostras provenientes de pomares cítricos localizados na China (CHEN et al., 2009).

As bactérias associadas ao HLB podem ser transmitidas por enxertia de tecidos infectados (COLETTA-FILHO et al., 2010) e por duas espécies de insetos vetores sugadores de floema, o psilídeo-asiático-dos-citros (Diaphorina citri Kuwayama) e o psilídeo-africanodos-citros (Trioza erytreae Del Guercio) (BOVÉ, 2006). Todas as variedades comerciais de 
laranjas doces cultivadas no Brasil são suscetíveis à infecção pelos patógenos associados ao HLB.

A dificuldade de controle do vetor contribui para a rápida disseminação da doença, uma vez que os insetos, frequentemente, atacam brotações novas, mesmo em períodos de baixo crescimento dos fluxos vegetativos (YAMAMOTO; ALVES; BELOTI, 2015). Ao se alimentar da seiva do floema das plantas cítricas contaminadas, o psilídeo, estando na fase de ninfa ou de adulto, pode adquirir ou inocular o patógeno (PARRA et al., 2017; INOUE et al., 2009). Os danos mais severos ocorrem, normalmente, entre um a cinco anos após a constatação dos primeiros sintomas (AUBERT, 1992). A bactéria é transmitida sistemicamente do sítio de infecção para diferentes órgãos das plantas, podendo ser detectada em folhas, raízes, flores, frutos e no tegumento de sementes. Embora seja encontrada em diferentes locais, a bactéria apresenta concentrações variadas nos tecidos de cada planta, além de ter uma distribuição irregular nas áreas infectadas (TATINENI et al., 2008).

Devido a um longo período latente entre a infecção e o aparecimento dos sintomas em árvores contaminadas, e também à semelhança dos sintomas com outros distúrbios fisiológicos e nutricionais, o diagnóstico do HLB não pode se basear apenas em sintomas visuais. Portanto, métodos tais como o PCR (Polymerase Chain Reaction - Reação em cadeia da Polimerase) quantitativo em tempo real (qPCR) são muito utilizados para o diagnóstico preciso desta doença, através da utilização de sondas de oligonucleotídeos que reconhecem sequências específicas do DNA do patógeno (BOAVA; CRISTOFANI-YALY; MACHADO, 2017; LI; LEVY; HARTUNG, 2006).

O aparecimento de folhas de coloração amarelo pálido em regiões setorizadas das plantas marca o início dos sintomas, e são facilmente diferenciadas da cor verde de ramos não afetados. Ocorre também a formação de manchas assimétricas nas folhas mais velhas, tornandoas curvadas e com nervuras espessas. Em estágios mais avançados, pode ocorrer a desfolha e a morte dos ponteiros (BELASQUE JR et al., 2010; BOVÉ, 2006). Os frutos produzidos por plantas infectadas são pequenos, assimétricos, sem sementes, com necroses de coloração amarelo-escuro no albedo, de baixa qualidade e sem comercialização (COLETTA-FILHO et al., 2010). Além disso, a degradação e a redução do sistema radicular também são constantemente observadas em plantas sintomáticas (JOHNSON; BRIGHT; GRAHAM, 2014). 
Alterações citológicas, tais como o colapso dos elementos de tubo crivado e de células companheiras do floema, o acúmulo de calose e amido, e o inchaço das lamelas médias da parede celular vegetal, têm sido constantemente associados ao desenvolvimento de sintomas de HLB em plantas cítricas (WANG et al., 2017; ACHOR et al., 2010). Ao serem contaminadas pelas bactérias, o metabolismo das plantas sofre severas desordens fisiológicas, e as principais alterações ocorrem em decorrência da formação de calose nos poros dos elementos de tubo crivado e nos plasmodesmos, que por sua vez, causam a obstrução floemática prejudicando as distribuições de fotoassimilados (BOAVA; CRISTOFANI-YALY; MACHADO, 2017).

Aparentemente, o bloqueio do floema associado ao HLB é resultante exclusivamente do acúmulo de calose produzido pelas plantas, um polissacarídeo $(1,3) \beta$-glucana de material amorfo e filamentoso, uma vez que, grandes agregados de $C$ Las seriam insuficientes para causar diretamente a obstrução floemática (ACHOR et al., 2010). Genes como Phloem Protein 1 (PP1) e Phloem Protein 2 (PP2), quando superexpressos, são capazes de sintetizar e regular proteínas que também estão envolvidas no processo de obstrução dos elementos de tubo crivado durante a infecção por CLas e que contribuem para o progresso da doença (WANG et al., 2017; DINANT et al., 2003).

Plantas infectadas por CLas são severamente afetadas resultando em alterações e perturbações no metabolismo, nos estímulos hormonais e na biossíntese de todos os metabólitos secundários (MAFRA et al., 2013). Desta forma, os efeitos secundários da doença, tais como o acúmulo de amido nas folhas e a diminuição do teor de carboidratos no sistema radicular, podem ser facilmente justificados pelo bloqueio de transporte do floema (JOHNSON; BRIGHT, GRAHAM, 2014). O excesso de amido em folhas com HLB pode causar o rompimento dos tilacoides, estruturas das membranas dos cloroplastos responsáveis pelo processo fotoquímico da fotossíntese (BONDADA; SYVERTSEN, 2005). Esse fenômeno pode explicar o surgimento do sintoma característico desta doença, o mosqueamento nas folhas, causado pelo amarelecimento irregular de folhas maduras, enquanto outros setores permanecem esverdeados.

Após o ataque de patógenos, o desenvolvimento de sintomas é desencadeado por numerosos fatores de ordem fisiológica e celular, além de alterações moleculares que também podem estar associados ao processo de defesa natural de plantas cítricas. Infecções bacterianas causam alterações na expressão de vários genes envolvidos no mecanismo de defesa de plantas, no metabolismo de proteínas e carboidratos, além de respostas aos estresses de origem biótica 
e abiótica (LUNA et al., 2011). A deposição de calose, sintetizada pela calose sintase, no local de infecção também pode ser considerada um eficiente mecanismo de defesa contra a colonização de patógenos em plantas hospedeiras, embora no patossistema HLB, este polissacarídeo seja considerado fator predominante na obstrução floemática de citros após a contaminação por Clas (OLIVEIRA et al., 2019; KOH et al., 2012).

Além de danos diretos causados após a infecção por patógenos, a absorção, a assimilação, o transporte e a utilização de nutrientes pelas plantas também podem ser seriamente afetados (MARSCHNER, 2012; DORDAS, 2008). O desbalanço nutricional que ocorre em árvores infectadas, comparadas àquelas sadias, é associado, principalmente, à redução da concentração de vários nutrientes minerais presentes nas folhas (MALAVOLTA et al., 2005). Os patógenos podem ainda imobilizar nutrientes nos tecidos infectados e causar deficiência ou toxicidade pela utilização desses elementos (HUBER; GRAHAM, 1999). Plantas cítricas com HLB apresentam reduções nos teores minerais foliares de nitrogênio $(\mathrm{N})$, potássio $(\mathrm{K})$, zinco $(\mathrm{Zn})$, cobre $(\mathrm{Cu})$, boro $(\mathrm{B})$, ferro $(\mathrm{Fe})$ e manganês $(\mathrm{Mn})$. Essas deficiências podem estar associadas a fatores tais como deficiência na assimilação pelo sistema radicular, e também, à baixa ou ausência de translocação de minerais pelo floema obstruído (MALAVOLTA et al., 2005).

Não existem métodos curativos economicamente e ambientalmente viáveis de controle do HLB em pomares comerciais (BASSANEZI et al., 2019). As principais medidas de controle recomendadas referem-se à prevenção da infecção, incluindo o plantio de mudas sadias, a eliminação de plantas sintomáticas e o controle do vetor (psilídeo) (GRAFTON-CARDWELL et al., 2013; BELASQUE JR et al., 2010). Diante da baixa eficiência dos métodos de controle adotados, à elevada taxa de infecção do patógeno, ao difícil manejo do inseto vetor e à ausência de resistência genética no gênero Citrus, há uma maior demanda na busca pelo desenvolvimento de cultivares resistentes ao HLB (MOURÃO FILHO; STIPP; MENDES, 2010).

Sintomas menos graves da doença e títulos bacterianos reduzidos têm sido frequentemente relatados em plantas de Poncirus trifoliata, indicando uma possível tolerância ou resistência desta espécie contra CLas (FOLIMONOVA et al., 2009). Estudos demonstraram que o híbrido US-897 (Citrus reticulata $\times$ Poncirus trifoliata) exibiu tolerância ao HLB em experimentos realizados em casa de vegetação nos Estados Unidos da América (ALBRECHT; BOWMAN, 2012). A análise transcricional desse híbrido revelou que vários genes estão potencialmente associados à tolerância a CLas (ALBRECHT; BOWMAN, 2012). Segundo os 
autores, a provável tolerância observada em Poncirus trifoliata e seus híbridos é justificada pela presença de certos compostos no interior dos elementos de tubo crivado, que restringem a proliferação ou movimentação de $C$ Las.

Desta forma, a produção de plantas transgênicas contendo um ou poucos genes que induzem a resistência a esta doença torna-se uma alternativa a ser avaliada no seu controle, tornando-se uma possível solução a longo prazo para garantir as viabilidades técnicas e econômicas da citricultura (RAMADUGU et al., 2016). Estudos realizados com diferentes genes associados à tolerância de plantas cítricas à infecção por CLas, indicaram variações na expressão daquele que codifica uma superóxido dismutase do cobre e do zinco ( $c s d l$, sugerindo-se seu possível envolvimento na defesa das plantas contra esse patógeno (ALBRECHT; BOWMAN, 2012).

\subsection{Cancro cítrico}

O cancro cítrico é uma doença endêmica na Índia, no Japão e em outros países do sudeste asiático, de onde se espalhou para outras regiões produtoras de citros, estando presente em vários países do mundo, podendo afetar todas as espécies e variedades comerciais de citros (DAS, 2003; GOTTWALD et al., 2001). No Brasil, a primeira constatação da doença foi em 1957, na região de Presidente Prudente, estado de São Paulo, disseminando-se e instalando-se, em seguida, em diversas regiões citrícolas (LEITE JR et al., 1987). Atualmente, o cancro cítrico está presente em 17,26\% das árvores do cinturão citrícola de São Paulo e Triângulo/Sudoeste Mineiro, número que corresponde a mais de 30 milhões de plantas contaminadas (FUNDECITRUS, 2020).

O cancro cítrico é uma doença bacteriana causada por Xanthomonas citri subsp. citri (Xcc) (SCHAAD et al., 2006). O agente causal é uma bactéria Gram-negativa, aeróbia, baciliforme, medindo 1,5-2,0 $\mu \mathrm{m} \times 0,5-0,75 \mu \mathrm{m}$, com um flagelo polar, pertencente ao grupo das proteobactérias (classe Gammaproteobacteria) (GOTTWALD et al., 1993). Quando cultivada em meio de cultura, a bactéria apresenta colônias de formato côncavo e com pigmentação amarelada e aspecto viscoso pela produção de polissacarídeos extracelulares, os quais têm a função de proteção contra dessecação, congelamento e incidência de radiação ultravioleta (BRUNINGS; GABRIEL, 2003). 
Essa bactéria não possui mecanismos de sobrevivência normalmente observados em outros patógenos, como plantas hospedeiras ou insetos vetores, infectando somente as plantas da família Rutaceae. O vento e a chuva são as principais formas de disseminação do patógeno, que podem penetrar nos tecidos vegetais pelos estômatos, hidatódios, lenticelas ou ferimentos e causar a infecção de plantas (BEHLAU; BELASQUE JR, 2014; GOTTWALD et al., 2002). A face abaxial das folhas por conter maior densidade de estômatos é mais suscetível à penetração da bactéria. Além disso, as folhas jovens com 50 a 85\% de expansão também são mais suscetíveis à infecção, pois, anatomicamente, o mesofilo foliar apresenta menor resistência (GOTTWALD; GRAHAM, 1992; GRAHAM et al., 1992). A colonização e a multiplicação deste patógeno ocorrem nos espaços intercelulares, sendo que as condições ideais para o crescimento e desenvolvimento da bactéria são temperaturas entre $28^{\circ} \mathrm{C}$ e $30^{\circ} \mathrm{C}$ e elevada umidade relativa. No ambiente, a Xcc consegue sobreviver por poucos dias em materiais inertes (FEICHTENBERGER et al., 2005).

Os sintomas do cancro cítrico podem ocorrer em folhas, frutos e ramos, surgindo entre duas a cinco semanas após a infecção do tecido vegetal pela bactéria. As lesões iniciais causadas nas folhas apresentam pontos escurecidos, com amarelecimento ao redor, evoluindo para pústulas circulares, de coloração castanha, salientes e corticosas podendo levar à desfolha total das plantas (BEHLAU; BELASQUE JR, 2014). O tamanho das lesões nas folhas pode atingir até 10 milímetros de diâmetro dependendo da suscetibilidade do hospedeiro (LEITE, 1990). Durante a frutificação, o período mais crítico para a infecção é nos primeiros 90 dias após a queda das pétalas, sendo que, as lesões apresentam a formação de anéis concêntricos, com rachaduras decorrentes da necrose e crescimento do tecido afetado, reduzindo sua qualidade (GRAHAM et al., 2004; GOTTWALD et al., 2002). Embora tais lesões não afetem as características internas do fruto, o impacto mais significativo resulta nas restrições às importações de cítricos originários de países ou regiões que possuam cancro cítrico, sendo esta considerada uma doença ‘quarentenária’ na Europa (GOTTWALD et al., 2002).

Uma das alterações anatômicas que ocorrem nos tecidos vegetais infectados por Xcc é a indução de hiperplasia (divisões mitóticas excessivas) e de hipertrofia celular (GABRIEL et al., 1989). Esse fenômeno ocasiona o rompimento da epiderme com a posterior formação de uma erupção no meio da lesão, resultando no sintoma característico da doença (SWARUP et al., 1992). Em resposta ao estresse biótico, a planta sofre um desequilíbrio hormonal provocado pela produção excessiva de etileno, ocasionando quedas prematuras do fruto, levando a sua não comercialização (BROWN, 2001). 
As principais medidas de controle do cancro cítrico baseiam-se na exclusão e erradicação do patógeno, além do manejo integrado da doença. Técnicas como o plantio de cultivares menos suscetíveis, implantação de quebra-ventos arbóreos, aplicação de bactericidas cúpricos e indutores de resistência são constantemente adotadas (BEHLAU; BELASQUE JR, 2014). Por várias décadas, a campanha de erradicação de árvores com cancro cítrico no estado de São Paulo evitou a entrada do patógeno em novas áreas de plantios comerciais de citros, apesar de não ter conseguido eliminar totalmente a presença da bactéria dos pomares. A legislação vigente, de acordo com a Instrução Normativa (IN 21 de 25/04/2018) do Ministério da Agricultura, Pecuária e Abastecimento (MAPA), prevê o controle da doença por meio do sistema de mitigação de risco (SMR). Esta medida permite a presença de plantas doentes em áreas produtivas, desde que, os citricultores adotem medidas de manejo do pomar que auxiliem na prevenção da chegada do patógeno na propriedade e na descontaminação de frutos (PORTARIA-5 COORDENADORIA DE DEFESA AGROPECUÁRIA DO ESTADO DE SÃO PAULO, de 20/05/2019).

Os genótipos de citros exibem diferentes níveis de resistência à Xcc, entretanto, todas as cultivares de laranja doce são consideradas suscetíveis (BOSCARIOL; TAKITA; MACHADO, 2016). Dentre os genótipos mais cultivados na produção de citros no Brasil, as laranjas doces precoces, em especial a laranja 'Hamlin' é considerada a mais suscetível ao cancro cítrico (SANCHES et al., 2014). Este fato vem causando elevados prejuízos e constantes reduções nas áreas de plantio dessa cultivar no estado de São Paulo. Considerando-se que não há cultivares resistentes, a transformação genética de variedades comerciais torna-se uma estratégia promissora no combate ao cancro cítrico (YANG et al., 2011).

\subsection{Transformação genética para resistência a doenças}

O uso de cultivares resistentes às principais doenças incidentes na citricultura é o método mais eficaz na obtenção de plantas com maior produtividade, resistência a estresses bióticos e abióticos e com frutos de melhor qualidade (MARCOLINI et al., 2015). Como os genes de resistência às principais doenças ainda não foram encontrados nos genótipos de plantas cítricas, comerciais ou não, a engenharia genética ou a transformação genética configura-se como uma importante alternativa na busca pela proteção de cultivares contra diferentes patógenos (BRUNINGS; GABRIEL, 2003). 
A transformação genética oferece a oportunidade de introduzir diretamente genes que podem melhorar a resistência a doenças e que não são encontrados em espécies sexualmente compatíveis, preservando as características genéticas da cultivar inicial (STOVER et al., 2010; VARDI; BLECHMAN; AVIV, 1990). Desta forma, a produção de plantas transgênicas pode ser uma ferramenta alternativa aos programas convencionais de melhoramento de citros, que apresentam dificuldades na aplicação destes métodos, em função da alta heterozigose e juvenilidade, poliploidia, esterilidade de pólen e do óvulo e incompatibilidade sexual das espécies cítricas (MACHADO et al., 2005).

O primeiro relato envolvendo a transformação genética de citros data da década de 1980, quando Kobayashi e Uchimiya (1989) utilizaram polietilenoglicol (PEG) com o objetivo de introduzir o DNA diretamente em protoplastos de laranja 'Trovita' (Citrus sinensis L. Osbeck). Desde então, alguns métodos de transformação genética têm sido constantemente empregados para citros, tais como a eletroporação de protoplastos (NIEDZ; MCKENDREE; SHATTERS JUNIOR, 2003), a transformação de protoplastos mediada por PEG (GUO et al., 2005), a introdução direta de DNA via bombardeamento de partículas em células in vivo (YAO et al., 1996), e a transformação via Agrobacterium tumefaciens (BOSCARIOL et al., 2006), sendo este o método mais utilizado e eficiente para a produção de plantas transgênicas de citros. Entretanto, o sucesso da transformação genética mediada por Agrobacterium depende de muitos fatores, entre eles, a estirpe e a concentração bacteriana, tempo de inoculação, condições para co-cultivo, seleção e regeneração de explantes, a afinidade com o genótipo e a construção gênica utilizada (GHORBEL et al., 2000).

Diversos genes de interesse agronômico têm sido utilizados na transformação genética de citros na busca de resistência a patógenos bacterianos (CARDOSO et al., 2010; MENDES et al., 2010; BARBOSA-MENDES et al., 2009; BOSCARIOL et al., 2006). Entre as diversas estratégias, citam-se a introdução de moléculas que codificam elicitores envolvidos nas respostas de defesa de plantas (GURR; RUSHTON, 2005), genes maiores de resistência (COLLINGE; LUND; THORDAL-CHRISTENSEN, 2008), genes que codificam proteínas relacionados à patogênese e genes que codificam peptídeos antimicrobianos (GURR; RUSHTON, 2005). Neste contexto, o uso de genes como o $c s d l$ e $d 4 e 1$, que estimulam o sistema de defesa das plantas ou que codificam peptídeos antimicrobianos, respectivamente, apresentam potencial para proteção de plantas cítricas contra CLas e Xcc. 


\subsection{Superóxido dismutase}

Estresses bióticos e abióticos são importantes fatores que podem influenciar no crescimento, desenvolvimento e produtividade das plantas. Quando ocorre o ataque de patógenos, sob condições de estresse, os vegetais respondem expressando grande número de genes relacionados ao mecanismo de defesa celular (HALLIWELL; GUTTERIDGE, 2000). Uma resposta imediata a nível molecular é a explosão oxidativa que desencadeia, entre outras reações químico-físicas, a produção de espécies reativas de oxigênio (em inglês, Reactive oxygen species - ROS). Os vegetais, assim como todos os organismos aeróbicos, estão continuamente sujeitos a produção de ROS, incluindo os superóxidos $\left(\mathrm{O}_{2}^{-}\right)$, o peróxido de hidrogênio $\left(\mathrm{H}_{2} \mathrm{O}_{2}\right)$ e o radical hidroxila altamente reativo $\left(\mathrm{OH}^{-}\right)$. Embora ROS sejam geradas por processos metabólicos, tais como na fotossíntese e na respiração celular, suas produções podem ser aumentadas por estímulos ambientais, e os seus acúmulos nas plantas são umas das principais causas de perdas de produtividades das culturas agrícolas (FOYER; NOCTOR, 2005).

O oxigênio molecular $\left(\mathrm{O}_{2}\right)$ é relativamente não reativo e não tóxico para as plantas, uma vez que, possui uma estrutura estável na distribuição dos elétrons na camada externa. Com a excitação e ativação desta camada, ocorre a formação de ROS, as quais são produzidas nas imediações do agente patogênico e acabam afetando diversas funções celulares por oxidarem proteínas, causarem peroxidação de lipídeos e danificarem ácidos nucléicos (FOYER et al., 1994). Por outro lado, o acúmulo de ROS induzido por estresse é neutralizado por eficientes sistemas antioxidantes presentes nas plantas com o objetivo de evitar danos celulares. Esses sistemas de defesa podem ser de origem enzimática ou não enzimática. As defesas não enzimáticas incluem compostos com propriedades antioxidantes, como o $\beta$-caroteno, $\alpha$ tocoferol (vitamina E) e ácido ascórbico. Os mecanismos de defesa enzimáticos envolvem as superóxidos dismutases (SODs), as enzimas do ciclo ascorbato-glutationa (ASC-GSH), glutationa redutase (GR), glutationa peroxidase (GPX), catalase (CAT), peroxidades (POX) entre outras (GRATÃO et al., 2005; MITTLER et al., 2004; ASADA, 1999).

As SODs são metaloenzimas localizadas em vários compartimentos celulares, e possuem três classes conhecidas que diferem entre si devido ao cofator de metal utilizado pela enzima, sendo eles: SOD de ferro, SOD de manganês e SOD de cobre-zinco (SUNKAR; KAPOOR; ZHU, 2006). As sequências primárias de Fe SOD e Mn SOD são relacionadas, 
enquanto $\mathrm{Cu}-\mathrm{Zn}$ SOD é distinta. Fungos e animais possuem Cu-Zn SOD e Mn SOD, enquanto algumas plantas e bactérias podem conter as três formas (BOWLER et al., 1992).

As SODs estão inseridas na primeira linha de defesa das plantas contra radicais superóxidos altamente tóxicos; catalisam a dismutação de $\mathrm{O}_{2}{ }^{-}$a $\mathrm{H}_{2} \mathrm{O}_{2}$ e $\mathrm{O}_{2}$, sendo que as ROS podem ser geradas em diversos compartimentos, a exemplo de cloroplastos, mitocôndrias e peroxissomos. A localização das SODs nos compartimentos celulares também é diferenciada (NAVROT, 2007). De maneira geral, as Mn SODs estão localizadas nas mitocôndrias e nos peroxissomos (DEL RIO et al., 1998), as Fe SODs nos cloroplastos (ASADA, 1999), e as CuZn SODs são encontradas no citosol e nos cloroplastos. Há também relatos de SOD no peroxissomos e no espaço extracelular (BUENO et al., 1995).

As ROS têm grande importância no sistema de defesa das plantas, pois sinalizam as vias de resposta a estresses bióticos e abióticos. Além disso, desempenham papel na ativação de moléculas de defesas após a infecção das plantas por patógenos (ABBÁ et al., 2009). Outros processos estão envolvidos em resposta à invasão de patógenos (Figura 1), tais como as reações catalisadas por peroxidases que induzem a polimerização de fenóis, assim como a formação de lignina e fortalecimento da parede celular através da formação de ligações cruzadas com proteínas estruturais, além de provocar a toxidez direta nas membranas dos patógenos (LABANCA, 2002). 


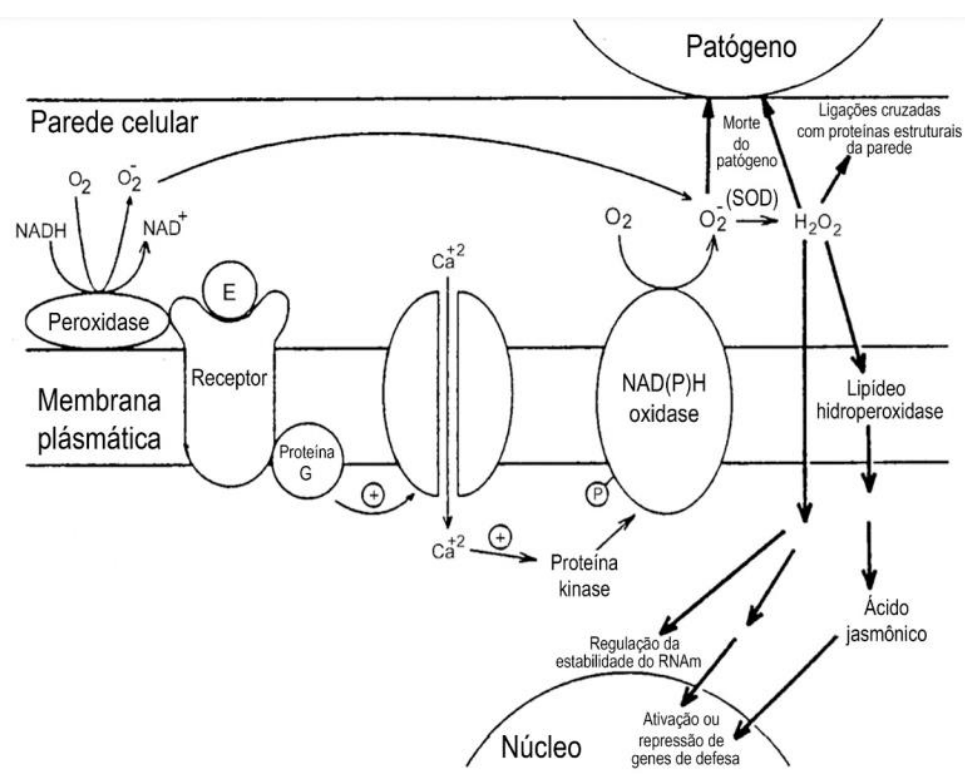

Figura 1. Componentes envolvidos na geração de ROS e seus efeitos sobre o patógeno ou sobre a ativação de mecanismos de defesa das plantas (retirada de STANGARLIN et al., 2011).

Além disso, o peróxido de hidrogênio atua como um importante regulador em processos fisiológicos, tais como senescência, fotorrespiração e fotossíntese, movimento estomático e ciclo celular (QUAN et al., 2008). Deste modo, o estresse oxidativo é relacionado à patofisiologia de diversas doenças. A regulação dos níveis de ROS pela superóxido dismutase têm um papel fundamental na sobrevivência de plantas em ambiente de tensões, de modo que a tolerância das plantas pode ser melhorada pelo aumento dos níveis in vivo de enzimas antioxidantes (MITTLER, 2002).

A superexpressão do gene $c s d l$, que codifica a enzima SOD do cobre e zinco, aumentam a resistência de plantas às condições de estresse oxidativo causados por estresses bióticos e abióticos (SUNKAR; KAPOOR; ZHU, 2006). Plantas transgênicas de tabaco com superexpressão de SOD Cu-Zn demonstraram tolerância aumentada ao ozônio e aos estresses causados por alta luminosidade e por baixa temperatura (BADAWI et al., 2004). Do mesmo modo, eventos de arroz transgênico codificando a enzima SOD $\mathrm{Cu}-\mathrm{Zn}$ mostraram maior tolerância à salinidade elevada e estresse hídrico do que arroz não transgênico (LU et al., 2011).

Em relação ao estresse causado por fatores bióticos, plantas de laranja 'Hamlin' expressando a enzima SOD $\mathrm{Cu}-\mathrm{Zn}$ demonstraram um aumento na indução da transcrição de genes $c s d 1$, a um nível 73 vezes maior, em folhas de Citrus infectadas por CLam quando comparadas a plantas não infectadas (MAFRA et al., 2013). Também houve alteração na expressão do gene $c s d l$ em plantas infectadas por CLas, em estudos que buscavam a 
identificação de genes associados à tolerância ao HLB (ALBRECHT; BOWMAN, 2012). Ambos os trabalhos citados sugerem o envolvimento do gene $c s d 1$ na proteção de plantas contra o HLB, o que permite crer que a utilização de plantas transgênicas contendo esse gene pode ser uma alternativa potencial para o controle de Candidatus Liberibacter spp. e de outras doenças bacterianas.

\subsection{Peptídeos antimicrobianos}

Os peptídeos antimicrobianos (em inglês, Antimicrobial peptides - AMPs) são um grupo diverso de moléculas biologicamente ativas com propriedades multidimensionais e sintetizadas por ribossomos (PUSHPANATHAN; GUNASEKARAN; RAJENDHRAN, 2016). Sua produção em plantas é intrínseca ou em resposta a injúrias e infecções, sendo um componente importante das defesas naturais contra patógenos invasores (GABAY, 1994). Tais peptídeos atuam contra diversos microrganismos, a exemplo de bactérias Gram-positivas e Gram-negativas, protozoários, leveduras, fungos e vírus. Acredita-se que a maioria dos peptídeos antimicrobianos danifica a membrana plasmática do invasor, inibindo a quitina sintase ou a $\beta$-D-glucana sintase, seguida pela formação de poros e lise celular (NIIDOME et al., 1999). Além disso, esses peptídeos também podem interferir na divisão celular, na síntese macromolecular e na formação de parede celular do hospedeiro (BOWDISH et al., 2005).

Os peptídeos antimicrobianos são produzidos naturalmente por organismos vivos, tais como insetos, vertebrados e plantas e podem ser eficientes atuadores na defesa contra diversos agentes patogênicos (ZASLOFF, 2002). Entretanto, os mecanismos de defesa natural das plantas nem sempre são suficientes para combater o ataque de patógenos e, por isso, uma grande variedade de peptídeos antimicrobianos tem sido isolada a partir de diferentes fontes, tais como plantas, animais e microrganismos. Por isso, a produção de peptídeos sintéticos é uma alternativa para a produção de plantas geneticamente modificadas mais resistentes ao ataque de patógenos (RAJASEKARAN et al., 2001).

As cecropinas representam uma classe de peptídeos antimicrobianos, pequenos e helicoidais, isolados da hemolinfa da mariposa (Hyalophora cecropia), atuando como importantes componentes no sistema de defesa dos insetos, e de grande potencial antibacteriano em ensaios in vitro (STEINER et al., 1981). O grupo das cecropinas pode ser subdividido em nativas (cecropina B), mutantes (SB37 e MB39) ou sintéticas (Shiva-1 e D4E1) (TRIPATHI; 
THIPATHI; TUSHEMEREIRWE, 2004). A expressão de peptídeos sintéticos em plantas apresenta algumas vantagens em relação a dos naturais, tais como o tamanho reduzido (10-20 aminoácidos), estabilidade, especificidade e eficiência em baixas concentrações, além de não oferecer riscos de contaminação ou toxicidade ao tecido vegetal transgênico (CARY et al., 2000). Dentre estes peptídeos, o D4E1 (17 aminoácidos), originário de cecropinas sintéticas, tem sido utilizado em diversos trabalhos de transformação genética (TRIPATHI; TRIPATHI, TUSHEMEREIRWE, 2004).

Os peptídeos antimicrobianos são atraídos pela membrana celular dos patógenos por possuírem cargas positivas. Desta forma, os aminoácidos se unem à bicamada lipídica e após a inserção na membrana causam a permeabilidade e lise celular. Além disso, os peptídeos podem penetrar no citosol e ligarem-se ao material genético do invasor causando a interrupção da replicação do DNA, da síntese de RNA e de outras atividades enzimáticas (MARCOS et al., 2008). O D4E1 interage com o ergosterol, um lipídeo específico de membranas de fungos. Plantas transgênicas expressando o gene $d 4 e 1$ têm apresentado resistência não somente a doenças fúngicas, mas também a doenças bacterianas, sugerindo que a interação com ergosterol não seja o único modo de ação deste peptídeo (RAJASEKARAN et al., 2001). Variedades de algodão transgênico expressando o gene $d 4 e 1$ inibiram o crescimento de Fusarium verticilloides e Verticillium dahliae, mostrando redução dos sintomas da podridão de raiz negra, causada por Thielaviopsis basicola (RAJASEKARAN et al., 2005). Plantas de tabaco transformadas com o gene $d 4 e 1$ apresentaram maior resistência à Colletotrichum destructivum, fungo causador da antracnose (CARY et al., 2000). Híbridos de álamos (Populus tremula L. x Populus alba L.) expressando o gene $d 4$ el diminuíram a severidade dos sintomas causados por Xanthomonas populis pv. populi e Agrobacterium tumefaciens (MENTAG et al., 2003).

As reduções dos danos causados por doenças bacterianas também foram demonstradas em estudos com plantas transgênicas que expressam a cecropina. A expressão do gene dmb39 de cecropina conferiu resistência à Pseudomonas syringae pv. tabaci em plantas transgênicas de tabaco, sendo que a multiplicação bacteriana nas folhas destas plantas foi dez vezes menor em comparação à registrada em plantas não transformadas (HUANG et al., 1997). Em plantas transgênicas de batata expressando o gene cecropin $S B-37$, foi observada maior resistência à infecção por Erwinia carotovora, bactéria causadora da canela preta e da podridão-mole (ARCE et al., 1999). 
Desta forma, os resultados favoráveis a partir de estudos utilizando os peptídeos antimicrobianos no controle de diferentes doenças tornam o seu uso bastante promissor na busca pela resistência de plantas cítricas transgênicas às principais doenças bacterianas, tais como o HLB e o cancro cítrico. Recentemente, compostos antibacterianos derivados de peptídeos antimicrobianos foram aprovados nos Estados Unidos da América para aplicação em árvores cítricas infectadas, auxiliando no manejo do HLB em pomares comerciais (CALLIES, 2017). Alguns testes iniciais com o gene $d 4 e 1$ foram realizados no United States Horticultural Research Laboratory, do Departamento de Agricultura dos Estados Unidos (USDA) utilizando cultivares transformadas de laranja 'Hamlin' e 'Valência', as quais indicaram baixa infecção por Xanthomonas citri subsp. citri (STOVER et al., 2010). 


\section{MATERIAL E MÉTODOS}

\subsection{Local dos experimentos}

Os experimentos foram realizados em casas de vegetação específicas para o cultivo de plantas transgênicas, instaladas em áreas do Departamento de Produção Vegetal e do Departamento de Fitopatologia e Nematologia da Escola Superior de Agricultura 'Luiz de Queiroz' (ESALQ), Universidade de São Paulo, em Piracicaba, SP (2242’29’'S; 47³7’41”O).

\subsection{Caracterização molecular}

\subsubsection{Construções gênicas e transformação genética}

Para os bioensaios visando avaliar a reação de eventos transgênicos à infecção por Xcc ou CLas, foram utilizadas plantas de laranja 'Hamlin' (Citrus sinensis L. Osbeck) transformadas com o gene csdl obtidas por Moraes (2015) e plantas da mesma cultivar transformadas com o gene $d 4 e 1$ obtidas por Attílio (2013). Essas plantas foram obtidas em experimentos de transformação genética, via Agrobacterium tumefaciens, estirpe EHA 105, a partir de segmentos de epicótilo de plântulas in vitro e cultivadas em casa de vegetação.

O gene $\operatorname{csdl}$ possui 459 pares de bases (pb), e foi identificado pelo grupo de pesquisa coordenado pela Dra. Juliana Freitas-Astúa (Embrapa Mandioca e Fruticultura) e isolado de Poncirus trifoliata. Foi clonado no vetor pCAMBIA2301, sob controle do promotor constitutivo UBI10 (Ubiquitina 10), que contém também o gene de seleção nptII (neomicina fosfotransferase II), que confere resistência ao antibiótico canamicina e o gene repórter uidA (beta-D-glucuronidase), ambos dirigidos pelo promotor 35S (Cauliflower mosaic virus 35S), pela empresa DNA Cloning Service (Alemanha) (Figura 2).

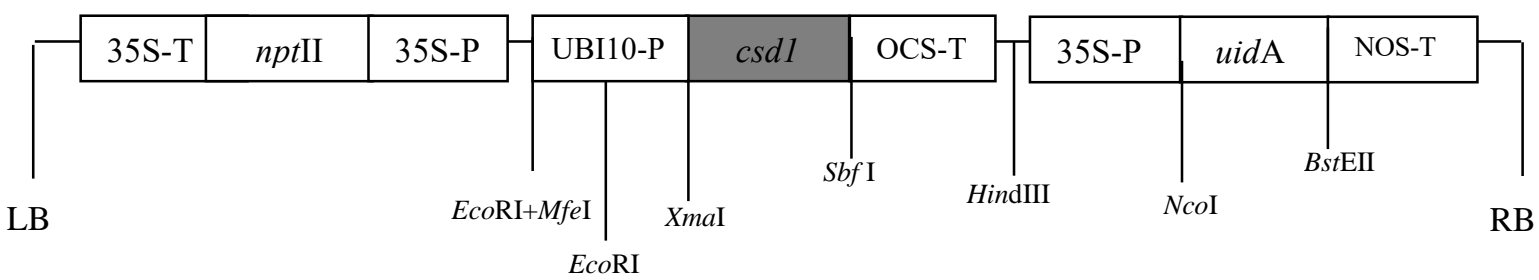

Figura 2. Representação esquemática do T-DNA (7.533 pb) do vetor de transformação pCAMBIA2301Ptcsdl, contendo o gene $c s d l$, o gene de seleção nptII (neomicina fosfotransferase II) e o gene repórter uidA. 35S-P: Promotor 35S; 35S-T: terminador 35S; UBI10: promotor Ubiquitina 10; OCS: terminador octopina sintase; NOS-T: terminador nopalina sintetase; LB: borda esquerda; RB: borda direita (MORAES, 2015). 
A síntese do gene $d 4 e 1$, que possui $69 \mathrm{pb}$, foi realizada pelo Dr. Ricardo Harakava (Instituto Biológico de São Paulo), assim como a elaboração do vetor de transformação, contendo esse gene. O gene $d 4 e 1$ foi clonado no vetor pCAMBIA2201, que contém também o gene de seleção nptII (neomicina fosfotransferase II). Ambos os genes são dirigidos pelo promotor 35S (Cauliflower mosaic virus 35S) (Figura 3).

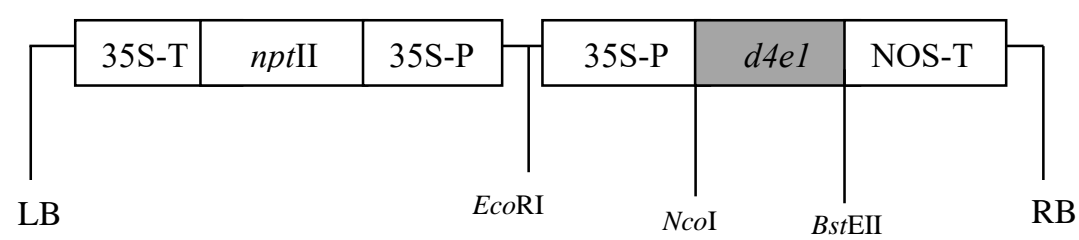

Figura 3. Representação esquemática do T-DNA (3.416 pb) do vetor de transformação pCAMBIA2201$d 4 e 1$, contendo o gene $d 4 e 1$ e o gene de seleção nptII (neomicina fosfotransferase II). 35S-P: Promotor 35S; 35S-T: terminador 35S; NOS-T: terminador nopalina sintetase; LB: borda esquerda; RB: borda direita (ATTÍLIO, 2013).

Análises moleculares das plantas de laranja 'Hamlin' transformadas com o gene csdl ou $d 4 e 1$ foram realizadas em trabalhos anteriores para confirmar a integração e a transcrição dos genes (MORAES, 2015; ATTíLIO, 2013). Nesses estudos, utilizaram-se as análises por PCR (Polymerase Chain Reaction - Reação em cadeia da Polimerase) para a confirmação da transgenia e as plantas com resultados positivos foram analisadas por Southern blot a fim de verificar a integração do gene no genoma das plantas e respectivo número de cópias (SOUTHERN, 1975). A análise de RT-qPCR (Reverse Transcription Quantitative PCR Transcrição Reversa seguida de PCR em tempo real) foi utilizada para quantificar o nível de expressão do transgene. Essas análises foram realizadas no Laboratório de Biotecnologia de Plantas Hortícolas da ESALQ e no Laboratório de Biotecnologia Vegetal do Centro de Energia Nuclear na Agricultura - CENA/USP.

\subsubsection{Quantificação de RNA mensageiro do gene $\operatorname{csd} 1$ em folhas de laranjeira doce}

A fim de obter maior precisão dos resultados obtidos, a quantificação da expressão do gene $c s d 1$ nas plantas transformadas foi repetida neste trabalho através da técnica de RT-qPCR. A análise do nível de mRNA do transgene $d 4 e 1$ foi realizada e validada em trabalhos anteriores (ATTíllo, 2013). 
A extração de RNA foi feita com 100 a 200 miligramas de tecido foliar das plantas matrizes transgênicas, não transgênicas e transgênicas com o vetor vazio (pCAMBIA2201), com o uso de TRIzol ${ }^{\circledR}(1 \mathrm{ml}$; Invitrogen) e do auxílio de um disruptor de tecidos (TissueLyser II - Qiagen; $30 \mathrm{hz}$; cinco minutos), conforme as indicações do fabricante. O RNA foi purificado utilizando o kit PureLink ${ }^{\mathrm{TM}}$ RNA / Mini Kit (Invitrogen) e tratado com DNase (RNAse-Free Water DNase Set-Invitrogen), de acordo com as instruções do fabricante. A quantificação do RNA foi realizada, utilizando-se um espectrofotômetro (NanoDrop ${ }^{\circledR}$ - 1000 Spectrophotometer - Thermo Scientific) e a sua pureza foi determinada pela razão de OD260/OD280 (com valores ideais de 1,8 a 2,2). A determinação da integridade do RNA foi realizada por meio de análise em gel de agarose $(1,5 \%)$, a 70 Volts $(\mathrm{V})$, por 50 minutos.

A síntese do cDNA foi realizada a partir de $1 \mu \mathrm{g}$ de RNA, $1 \mu \mathrm{L}$ de primer oligo dT $(10 \mu \mathrm{M}), 1 \mu \mathrm{g}$ de mix de dNTP $(10 \mathrm{mM})$ e água ultrapura livre de RNAse, para um volume final de $10 \mu \mathrm{L}$. A reação foi incubada a $65^{\circ} \mathrm{C}$ a cinco minutos e, posteriormente, acondicionada em gelo por três minutos. Foram adicionadas à reação, $4 \mu \mathrm{L}$ de tampão First Strand, $2 \mu \mathrm{L}$ de DDT $(0,1 \mathrm{M})$ e $1 \mu \mathrm{L}$ de RNaseOUT (Invitrogen), incubadas a $37{ }^{\circ} \mathrm{C}$ por dois minutos. Adicionou-se $1 \mu \mathrm{L}$ da enzima transcriptase reversa M-MLV (Invitrogen) permanecendo a 37 ${ }^{\circ} \mathrm{C}$ por 50 minutos. Para inativação da atividade enzimática, a reação foi incubada por 15 minutos a $70^{\circ} \mathrm{C}$, e em seguida, as amostras de cDNA foram normalizadas para $10 \mathrm{ng} \mu \mathrm{L}^{-1} \mathrm{e}$ armazenadas a $-20^{\circ} \mathrm{C}$. O cDNA obtido foi submetido a PCR. Como controle negativo da reação, foi utilizado o mRNA de uma planta não transgênica, conforme o realizado por Moraes (2015).

A análise de RT-qPCR foi realizada no Laboratório de Biotecnologia de Plantas Hortícolas, do Departamento de Produção Vegetal (ESALQ/USP), através do equipamento 7500 FAST $^{\mathrm{TM}}$ Real-Time PCR System (Applied Biosystems, Foster City, USA). Para a análise da transcrição do transgene $c s d 1$ foram utilizados dois genes de referência (UBC21 e DIM1), com sequências de primers definidas por MAFRA et al. (2012) (Tabela 1). 
Tabela 1. Sequência de primers utilizados para a amplificação dos genes de referência $U B C 21$ e $D I M 1$, e do gene $\operatorname{csdl}$ na análise de RT-qPCR.

\begin{tabular}{lcc}
\hline \multicolumn{1}{c}{ Gene } & Sequência 5' - 3' $\mathbf{F}$ & Sequência 5' - 3' $\mathbf{R}$ \\
\hline UBC21 & CCTCCACAAGTGCGGTTTTTAA & CTGGGCTCCATGCGTTCTT \\
$D I M 1$ & CGAAACCTGTATGCAGATGG & ACGGTTGAGGGATCGTAAAG \\
$c s d 1$ & TCTTGGTGGAACTGAGGGTG & ATGAGGACCAGGCTTGAGAC \\
\hline
\end{tabular}

Fonte: Moraes (2015).

Para o procedimento de RT-qPCR, foram utilizados $2 \mu \mathrm{L}$ do cDNA diluído (10 ng $\left.\mu \mathrm{L}^{-1}\right), 0,15 \mu \mathrm{L}$ do conjunto de primers $(10 \mu \mathrm{M}), 6 \mu \mathrm{L}$ de Gotaq ${ }^{\circledR}$ qPCR Master Mix (Promega) e $1,7 \mu \mathrm{L}$ de água isenta de nuclease. A reação resultante foi pipetada em placa de 96 poços $(0,1$ ml; MicroAmp - Applied Biosystems). As amostras foram analisadas em três replicatas biológicas e em duas replicatas técnicas para cada planta e para o gene analisado, incluindo amostras de plantas não transgênicas, nas condições de amplificação padrão (FAST), seguindo o programa: 1 ciclo de dois minutos a $95^{\circ} \mathrm{C}$, seguido de 40 ciclos de três segundos a $95^{\circ} \mathrm{C}$, e 30 segundos a $60^{\circ} \mathrm{C}$. O ponto de fusão médio dos amplicons por meio da análise de Melting foi determinado ao final da reação, submetendo-se as amostras a $95^{\circ} \mathrm{C}$ por 15 segundos, aquecendo-as gradativamente de $60-95^{\circ} \mathrm{C}$ (taxa de aquecimento de $0,3{ }^{\circ} \mathrm{C}$ por segundo) e, finalmente, mantendo-as a $60^{\circ} \mathrm{C}$ por 15 segundos (MORAES, 2015; TAVANO, 2013). O valor do ciclo de quantificação $(\mathrm{Cq})$ foi determinado para o gene alvo $\operatorname{csdl}$ e para os dois genes de referência em cada evento de transformação. O software LinRegPCR (RAMAKERS et al., 2003) foi utilizado para avaliar a eficiência de reação de cada gene.

Após os cálculos da eficiência, os dados de Cq produzidos através das análises de RTqPCR foram analisados no software REST ${ }^{\circledR}$ (PFAFFL; HORGAN; DEMPFLE, 2002) e o cálculo da expressão gênica foi realizado pelo método $\Delta \Delta$ Cq. Como calibrador, foi utilizada a planta testemunha de menor expressão, ou seja, a planta com maior valor de Cq. As análises estatísticas foram realizadas pelo software $\mathrm{REST}^{\circledR}$ e os dados foram submetidos à análise de variância e as médias comparadas pelo teste de Dunnett $(P<0,05)$.

\subsection{Multiplicação vegetativa das plantas transgênicas e não transgênicas}

A seleção dos eventos contendo o gene $c s d l$ ou $d 4 e l$ foi realizada a partir da confirmação do número de cópias e expressão gênica nas plantas matrizes. Não houve 
alterações aparentes dos fenótipos das plantas transgênicas avaliadas. Eventos transgênicos de laranja 'Hamlin' expressando os genes $c s d l$ ou $d 4 e l$ foram multiplicadas vegetativamente a partir de borbulhas das respectivas plantas matrizes de cada evento pelo método da enxertia do tipo 'T invertido' em porta-enxertos de limão ‘Cravo' (Citrus limonia Osbeck), adquiridos de viveiro certificado (Figura 4). A multiplicação vegetativa das plantas não transgênicas (Testemunhas) também foi realizada pelo mesmo método. A enxertia foi realizada em agosto de 2016, obtendo plantas suficientes para a condução de experimentos independentes, destinando-se às avaliações de resistência para os dois patógenos estudados.

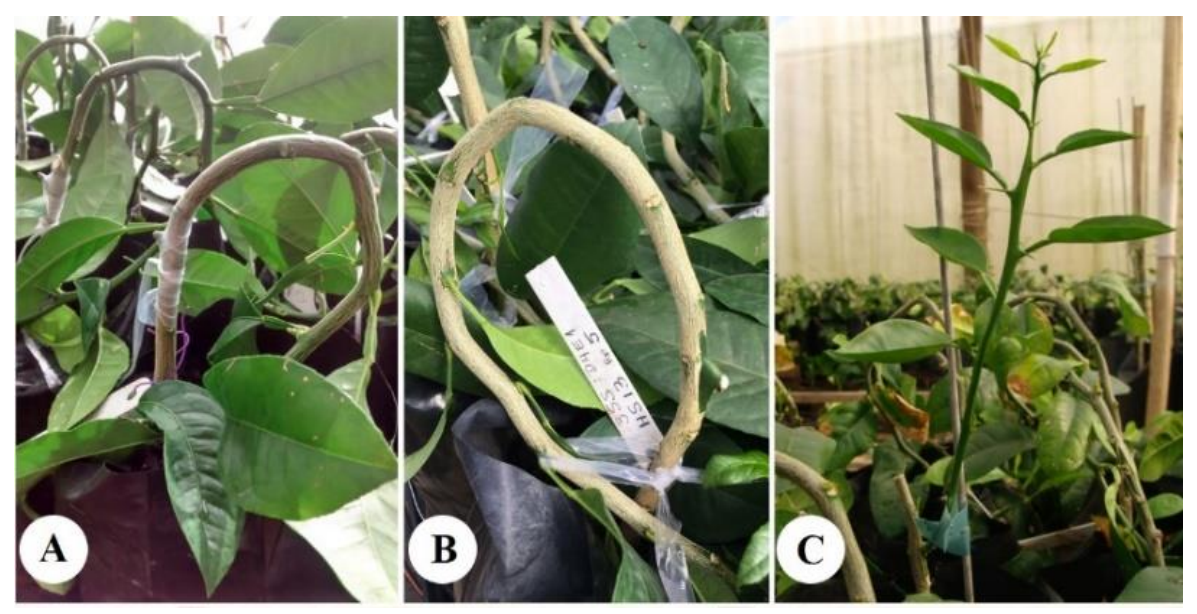

Figura 4. Multiplicação vegetativa de plantas transgênicas de laranja 'Hamlin'. (A) Plantas de limão 'Cravo' recém-enxertadas. (B) Retirada de fitilhos 20 dias após a enxertia. (C) Desenvolvimento do clone transgênico 55 dias após a enxertia da borbulha, em Piracicaba, SP.

As plantas foram cultivadas em sacos plásticos de polietileno (3,5 litros) contendo substrato comercial de casca de pinus (Multiplant 1075 Citros $^{\circledR}$ ) misturado com fertilizante Osmocote ${ }^{\circledR}$ PRO 15-09-12, na proporção 8 gramas (g) do produto para cada 1 litro de substrato. As plantas foram fertirrigadas quinzenalmente com macro e micronutrientes [Kristalon ${ }^{\circledR}(06$ 12-36, 0,8 $\left.\mathrm{g} \mathrm{L}^{-1}\right)$, ferro EDTA $\left(0,04 \mathrm{~g} \mathrm{~L}^{-1}\right)$ e nitrato de cálcio $\left.\mathrm{Ca}\left(\mathrm{NO}_{3}\right)_{2}\left(0,8 \mathrm{~g} \mathrm{~L}^{-1}\right)\right]$, alternandose os fertilizantes de acordo com a necessidade. As pulverizações das plantas contra pragas e doenças ocorreram quinzenalmente com alternância de produtos dos grupos químicos piretróide, avermectina, organofosforado e neonicotinóide. As podas e conduções das plantas foram realizadas sempre que necessárias ou após o encerramento das avaliações e/ou coletas de amostras. 


\subsection{Tratamentos e delineamento experimental}

Foram instalados experimentos independentes para a avaliação da resistência das plantas transgênicas de laranja 'Hamlin' contendo os genes $c s d 1$ ou $d 4 e 1$, associados a dois patógenos diferentes. As avaliações da resistência de plantas à infecção por Xanthomonas citri subsp. citri $(X c c)$ e Candidatus Liberibacter asiaticus (CLas) foram realizadas para os dois genes, independentemente. $\mathrm{O}$ delineamento experimental utilizado foi $\mathrm{o}$ inteiramente casualizado (DIC). Cada evento de transformação contendo o gene csdl ou $d 4$ el foi considerado como um tratamento, realizando-se 12 repetições (plantas clones) de cada evento. Além destes eventos, cada experimento incluiu dois tratamentos com plantas não transgênicas e dois tratamentos com plantas transformadas com vetor vazio da mesma cultivar em análise, também com 12 repetições cada. Os experimentos foram, portanto, compostos dos seguintes tratamentos:

Gene csd1: 13 eventos de transformação (TG3-14; TG3-16; TG3-19; TG3-26; TG4-2; TG4-3; TG4-4; TG4-6; TG4-9; TG4-11; TG4-28; TG4-33; TG4-37), Testemunha (T1 - plantas não transgênicas da mesma cultivar, obtidas a partir de tecido juvenil), Vetor vazio (V1 pCAMBIA2201).

Gene d4e1: 10 eventos de transformação (HS1; HS9; HS11; HS12; HS13; HS33; HS36; HS38; HS45; HS48), Testemunha (T2 - plantas não transgênicas da mesma cultivar, obtidas a partir de tecido juvenil), Vetor vazio (V2 - pCAMBIA2201).

\subsection{Reação de plantas transgênicas de laranja doce à infecção por Candidatus Liberibacter asiaticus}

\subsubsection{Inoculação de $C$ Las}

A inoculação de CLas em plantas transgênicas de laranja 'Hamlin', expressando o gene $\operatorname{cs} d l$ ou $d 4 e l$, e também em plantas não transgênicas da mesma cultivar, foi realizada em janeiro de 2018, ou seja, dezesseis meses após a enxertia. O método de inoculação foi por enxertia de borbulhão infectado com a bactéria CLas, o qual tem acarretado uma maior eficiência de transmissão comparado a outros métodos (COLETTA-FILHO et al., 2010; LOPES; FRARE, 2008). Os ramos infectados foram coletados de plantas cítricas da mesma cultivar mantidas em casa de vegetação do Fundo de Defesa da Citricultura (FUNDECITRUS), 
em Araraquara-SP, por meio da colaboração do Dr. Nelson Arno Wulff. O material vegetal foi retirado de plantas sintomáticas e, posteriormente, realizou-se, no Laboratório de Biotecnologia do FUNDECITRUS, o teste de confirmação da presença do patógeno, por qPCR, das plantasinóculo.

Um borbulhão infectado com aproximadamente quatro centímetros de comprimento foi enxertado em cada planta com auxílio de fitilhos plásticos, sendo retirados 20 dias após esse procedimento. Após a inoculação, foram realizados acompanhamentos semanais para analisar a taxa de 'sucesso' da enxertia do borbulhão infectado.

\subsubsection{Avaliação da detecção e quantificação de $C$ Las}

A detecção e a quantificação de CLas foi realizada por análises de qPCR no Laboratório de Biotecnologia de Plantas Hortícolas - ESALQ/USP. A quantificação de CLas nos eventos estudados foi realizada em três ocasiões, em julho de 2018, janeiro de 2019 e julho de 2019, ou seja, aos seis, 12 e 18 meses após a inoculação do patógeno, respectivamente. A concentração do título bacteriano de CLas no tecido vegetal foi estimada por meio da construção de curva padrão, conforme metodologia desenvolvida por Coletta-Filho et al. (2010).

\section{Extração de DNA de folhas}

A extração de DNA das plantas de laranja 'Hamlin' contendo ou não o gene csdl ou $d 4 e 1$ foi realizada utilizando-se tampão CTAB conforme o método descrito por Murray e Thompson (1980), com poucas modificações, a partir dos pecíolos e da nervura central das folhas. As análises ocorreram de forma individual para cada planta, utilizando-se oito repetições (plantas) de cada evento ou tratamento para a quantificação. Em cada repetição, foram selecionadas cinco folhas, coletadas aleatoriamente das regiões do terço inferior, médio e superior da planta, entre a $2^{\mathrm{a}}$ e $8^{\mathrm{a}}$ gema lateral, utilizando-se um pool de amostras. Após a coleta das folhas, cerca de 250 miligramas de pecíolos foram cortados em pequenos pedaços com o auxílio de uma lâmina, transferidos para tubos de Eppendorf ${ }^{\circledR}$ de $2 \mathrm{~mL}$, e armazenados em freezer $\left(-80^{\circ} \mathrm{C}\right)$ até o momento da extração.

Às amostras do material vegetal, foram adicionados $1 \mathrm{~mL}$ de Tampão $1(10 \mathrm{~mL}$ de Tris $\mathrm{HCl}$ pH 7,5 1M; 2 mL EDTA 0,5 M; 14 mL NaCl 5 M; 34 mL de água Milli-Q) e, em seguida 
foram maceradas por cinco minutos com o auxílio do disruptor de tecidos TissueLyser ${ }^{\circledR}$. Adicionaram-se $500 \mu \mathrm{L}$ do Tampão 2 (4 mL PVP 10\%; $32 \mu \mathrm{L}$ de mercaptoetanol 140 mM; 4 mL CTAB 5\%) na capela a este conteúdo, agitando-se, cuidadosamente. As amostras foram colocadas em banho-maria, a $65^{\circ} \mathrm{C}$, por 30 minutos, e após esse procedimento foram centrifugadas a 6.500 rotações por minuto $(\mathrm{rpm})$, por cinco minutos, a $4{ }^{\circ} \mathrm{C}$. Retiraram-se 700 $\mu \mathrm{L}$ do sobrenadante formado e acrescentou-se o mesmo volume de CIA (Clorofórmio/Álcool Isoamílico 24:1), em seguida, eles foram misturados por inversão, por dois minutos. As amostras foram novamente centrifugadas a $13.000 \mathrm{rpm}$ por cinco minutos, retiraram-se $500 \mu \mathrm{L}$ do sobrenadante, e o conteúdo foi transferido para novo tubo com $300 \mu \mathrm{L}$ de álcool isopropílico. Após serem misturadas por inversão, as amostras foram armazenadas por 15 minutos no freezer $\left(-80^{\circ} \mathrm{C}\right)$ para precipitação do DNA. Em seguida, as amostras foram novamente submetidas a centrifugação (13.000 rpm por 20 minutos, a $4{ }^{\circ} \mathrm{C}$ ), descartou-se o sobrenadante e em seguida, foram adicionados $500 \mu \mathrm{L}$ de álcool etílico $(70 \%)$ sobre o pellet. Os procedimentos de centrifugação e adição de álcool etílico foram repetidos nas mesmas condições por cinco minutos e o sobrenadante novamente descartado. Após essa etapa, os tubos permaneceram na capela de exaustão por 40 minutos para secagem dos pellets contendo o DNA. Acrescentaramse $50 \mu \mathrm{L}$ de água Milli-Q autoclavada para ressuspender o pellet e as amostras foram armazenadas a $-20{ }^{\circ} \mathrm{C}$ até a realização da análise da qPCR.

qPCR para a detecção e quantificação de CLas

A quantificação do DNA de cada amostra foi realizada com o auxílio do equipamento Nano Drop ${ }^{\circledR}$ (1000 Spectrophotometer - Thermo Scientific) e as informações referentes a pureza das amostras de DNA foram verificadas por meio da razão A260/A280. O DNA foi diluído para uma concentração final de $50 \mathrm{ng} \mu \mathrm{L}^{-1}$. A análise de $\mathrm{qPCR}$ foi realizada utilizandose o equipamento 7500 FAST $^{\mathrm{TM}}$ Real-Time PCR System (Applied Biosystems, Foster City, USA). A reação foi desenvolvida em uma solução total de $15 \mu \mathrm{L}$ contendo 7,5 $\mu \mathrm{L}$ do reagente SYBR Green PCR Master Mix (Applied Biosystems $\left.{ }^{\circledR}\right), 1 \mu \mathrm{L}$ de cada primer $(1 \mu \mathrm{M})$ AS84FCLas: 5'-TCACCGGCAGTCCCTATAAAAGT-3' e AS180R-CLas: 5'GGGTTAAGTCCCGCAACGA-3' (COLETTA-FILHO et al., 2010), $2 \mu$ L de DNA genômico (diluído em $50 \mathrm{ng} \mu \mathrm{L}^{-1}$ ) e 3,5 $\mu \mathrm{L}$ de água Milli-Q.

O programa utilizado para a amplificação do DNA foi o modo FAST (96 wells) sendo um ciclo inicial a $95^{\circ} \mathrm{C}$ por dois minutos; 40 ciclos a $95^{\circ} \mathrm{C}$ por três segundos (desnaturação); $60{ }^{\circ} \mathrm{C}$ por 30 segundos (anelamento) e, para obtenção da curva de melting, de 60 a $95^{\circ} \mathrm{C}$ por 20 
segundos. A análise das amostras foi realizada em duplicata técnica seguido pelo cálculo das médias e os dados foram analisados no 7500 Software v2.3. Como controle positivo, foi utilizado o material genético de plantas previamente infectadas (comprovadas por qPCR), e como controle negativo foi utilizado o material vegetal de plantas testemunhas. O Ciclo threshold $(\mathrm{Ct})$ é o ponto que detecta o ciclo na qual a reação atinge o limiar da fase exponencial, permitindo correlacionar o aumento da fluorescência com a quantidade inicial do DNA alvo obtido de cada amostra.

O limiar de Ciclo threshold utilizado para a comprovação da infecção de CLas foi de $\mathrm{Ct} \leq 36$, sendo que, para valores superiores não houve a detecção da bactéria. Procedeu-se a análise de variância dos dados, e as médias foram comparadas de acordo com o teste de Dunnett $(P<0,05)$, utilizando-se o software $\mathrm{SAS}^{\circledR}$.

Construção da curva padrão para quantificação do título bacteriano

A validação do limite de detecção e a quantificação dos amplicons de interesse foram realizadas pela construção de curva padrão baseada em concentrações conhecidas do fragmento alvo de rDNA da região 16S de CLas clonado em um plasmídeo pGEM contendo um inserto de $608 \mathrm{pb}$.

Para a construção da curva padrão, o DNA total de uma planta de laranja ‘Hamlin' não transgênica inoculada com $C$ Las (qPCR positivo) foi utilizada para amplificar o fragmento alvo através do conjunto de primers LAS-F externo e LAS-R externo (COLETTA-FILHO et al., 2010). O fragmento alvo esperado foi separado por eletroforese em gel de agarose low melting $2 \%$, isolando-se a banda in situ e procedendo sua purificação através do Kit de recuperação QIAEX II Gel Extraction, de acordo com as instruções do fabricante. O DNA purificado foi eluído e utilizado para a ligação do fragmento com o plasmídeo pGEM T-easy. A solução do plasmídeo recombinante foi utilizada para transformar células competentes de Escherichia coli DH5 $\alpha$. O plasmídeo recombinante contendo a inserção foi extraído e purificado com o kit Miniprep - Wizard ${ }^{\circledR}$ Plus SV (Promega) seguindo as instruções do fabricante, sequenciado no Laboratório de Genômica e Biologia Molecular do Centro de Biotecnologia Agrícola (CEBETEC, ESALQ/USP), e alinhado utilizando-se o programa BLAST ${ }^{\circledR}$ (Basic Local Alignment Search Tool). A concentração da solução do plasmídeo foi quantificada através do espectrofotômetro Nano Drop ${ }^{\circledR}$ (1000 Spectrophotometer - Thermo Scientific). 
A curva padrão foi construída utilizando RT-qPCR a partir de diluições seriadas e decimais do plasmídeo original. Foram empregadas seis diluições em série da solução de DNA plasmidial a partir de $10 \mathrm{ng} \mu \mathrm{L}^{-1}$ até $1 \mathrm{fg} \mu \mathrm{L}^{-1}$. A curva foi estabelecida relacionando-se as concentrações conhecidas de DNA ( $\mathrm{Ct}$ - eixo y) com os respectivos valores de log 10 do número de cópias (NC) do gene 16S rDNA (eixo x). A fórmula utilizada para calcular o número de cópias ([NC] de 16S rDNA por $\mu \mathrm{L}$ ) foi baseada no trabalho de WANG et al. (2006):

$$
\mathrm{NC}=(\mathrm{MxN}) /(\mathrm{LxD})
$$

Onde $\mathrm{M}=$ concentração mínima de ácido nucléico detectado $\left(\mathrm{g} \mathrm{ml}^{-1}\right) ; \mathrm{N}=$ Constante de Avogadro $\left(6,022 \times 10^{23}\right.$ moléculas $\left./ \mathrm{mol}\right) ; \mathrm{L}=$ comprimento do ácido nucleico em $\mathrm{kpb}$ (comprimento total do plasmídeo de inserção, sendo este $3623 \mathrm{pb}$ ); $\mathrm{D}=$ fator de conversão a partir de $1 \mathrm{kpb}$ de ácido nucleico para Daltons (dsDNA=6,6×10 $\mathrm{g} / \mathrm{mol} \mathrm{Kbp).}$

\section{Análise dos dados}

As análises estatísticas foram realizadas para verificar diferenças em relação às concentrações de CLas entre as plantas, comparando-se os valores obtidos das plantas transgênicas com as das plantas não transgênicas, pelo teste de Dunnett $(P<0,05)$. Os resultados foram submetidos à análise de variância, utilizando-se o software $\mathrm{SAS}^{\circledR}$.

\subsubsection{Análises microscópicas: detecção de calose em folhas de laranjeira doce}

A detecção de calose foi realizada em amostras de pecíolos de folhas de eventos-elite, de acordo com os melhores resultados obtidos de avaliações de resistência das plantas transgênicas, contendo o gene $c s d l$ ou $d 4 e l$ infectadas com $C$ Las, coletadas de posição e estágio de desenvolvimento semelhantes (plantas com 18 meses após a inoculação). O experimento foi repetido em cinco plantas diferentes de cada evento, coletando-se quatro folhas por planta. Seções longitudinais e transversais de $25 \mu \mathrm{m}$ de espessura foram cortadas frescas com o auxílio de um micrótomo de deslize (Leica SM2000 R, Wetzlar, Alemanha), coradas com 1\% de azul de anilina (diluído em álcool a 70\%) por dez minutos e submetidas a uma bomba de vácuo para remoção do ar dos espaços intercelulares. As amostras foram examinadas utilizando-se um filtro A4 (excitação 340-380 nm, 450-490 nm) no microscópio de epifluorescência Leica DM5000 B (Leica ${ }^{\mathrm{TM}}$, Wetzlar, Alemanha). Todas as imagens foram adquiridas por um sistema de câmera de vídeo DFC365 FX (Leica ${ }^{\mathrm{TM}}$, Wetzlar, Alemanha) acoplada a um computador, 
utilizando o software Leica Application Suite (LAS AF). A calose presente no floema de cada amostra foi analisada de forma qualitativa e comparada entre os eventos transgênicos e plantas não transgênicas.

\subsubsection{Determinação da matéria seca das plantas e análise química das folhas}

As plantas foram coletadas de forma destrutiva aos 18 meses após a inoculação com CLas para a determinação da matéria seca da parte aérea e do sistema radicular dos eventos transgênicos e não transgênicos, assim como das plantas não inoculadas com CLas de laranja 'Hamlin'. Cinco plantas de cada evento foram selecionadas para a realização desta análise. O material vegetal foi seco em estufa de circulação de ar forçada a $65^{\circ} \mathrm{C}$, durante três dias, para a posterior quantificação da matéria seca.

Para a quantificação dos teores de macronutrientes, foram coletadas 40 folhas de oito plantas obtendo-se uma amostra composta para a diagnose foliar. A amostragem foi realizada aos seis e 18 meses após a inoculação de $C$ Las, coletando-se sempre a $3^{\text {a }}$ ou $4^{\text {a }}$ folha, a partir da extremidade do ramo vegetativo, seguindo a recomendação para o diagnóstico nutricional de citros no estado de São Paulo. As folhas com sintomas severos de HLB não foram coletadas para a análise. Após a coleta, as amostras compostas foram armazenadas em sacos de papel identificados, secas em estufa de circulação de ar forçada a $65^{\circ} \mathrm{C}$, durante três dias e moídas. Os teores de nutrientes minerais provenientes das folhas foram analisados de acordo com o método descrito por Bataglia et al. (1983). Os resultados de macronutrientes obtidos nos períodos avaliados foram interpretados de acordo com os critérios estabelecidos pelo Grupo Paulista de Adubação e Calagem para Citros (1994).

\subsubsection{Análise da distribuição espacial de macro e micronutrientes através da espectroscopia de fluorescência de raios $X$ com feixe micrométrico ( $\mu$-XRF) em folhas de laranjeira doce}

A espectroscopia de fluorescência por raios $X$ é uma ferramenta analítica bem estabelecida utilizada para avaliações qualitativas e quantitativas multielementares. A medição por espectroscopia de fluorescência de raios $\mathrm{X}$ com feixe micrométrico $(\mu-\mathrm{XRF})$ é realizada pela determinação da energia emitida e o número de fótons fluorescentes (diretamente 
proporcionais à concentração do elemento no material vegetal) emitida por uma amostra excitada por partículas ou por um feixe de raios X (MONTANHA et al., 2020).

Desta forma, análises da distribuição espacial de macronutrientes (fósforo, potássio, cálcio e enxofre) e micronutrientes (manganês, ferro, cobre e zinco) em folhas de laranja 'Hamlin' não transgênicas, 18 meses após a inoculação por CLas, e em folhas de laranja 'Hamlin' não inoculadas foram realizadas por meio da espectroscopia por fluorescência de raios X. As análises foram realizadas no Laboratório de Instrumentação Nuclear do Centro de Energia Nuclear na Agricultura (CENA/USP).

Para a avaliação dos macronutrientes e micronutrientes, seis amostras da terceira folha de ramos da região intermediária de plantas de laranja 'Hamlin' com e sem HLB foram coletadas e secas a $65^{\circ} \mathrm{C}$ em estufa de circulação de ar forçada por 72 horas. As folhas foram fixadas em um suporte de acrílico contendo um filme de polipropileno (VHG, EUA) com $6 \mu \mathrm{m}$ de espessura e transferidas para o espectrômetro de fluorescência de raios $X$ com feixe micrométrico ( $\mu$-XRF, Orbis PC, EDAX, EUA). As amostras foram expostas a um feixe de raios $\mathrm{X}$ com aproximadamente $30 \mu \mathrm{m}$ de diâmetro, gerado por um anodo de ródio operando a $30 \mathrm{kV}$ e $300 \mu \mathrm{A}$ para a análise dos macronutrientes, e a $45 \mathrm{kV}$ e $500 \mu \mathrm{A}$ para a análise dos micronutrientes, sob atmosfera à vácuo (Figura 5). Duzentos e cinquenta e seis pontos foram coletados em cada folha linha, região de análise foliar, com comprimentos variando entre 38 e $70 \mathrm{~mm}$. Cada ponto foi investigado durante dez segundos para a avaliação dos macronutrientes e por 20 segundos, para os micronutrientes. Duas replicatas (linhas) foram coletadas e mapeadas em cada folha. Os espectros de raios $\mathrm{X}$ foram coletados por um detector semicondutor Si drift (SDD). O tempo morto (período no qual o detector não captou os fótons de fluorescência durante a análise) foi menor que $10 \%$. Todas as análises foram realizadas em triplicatas biológicas. 


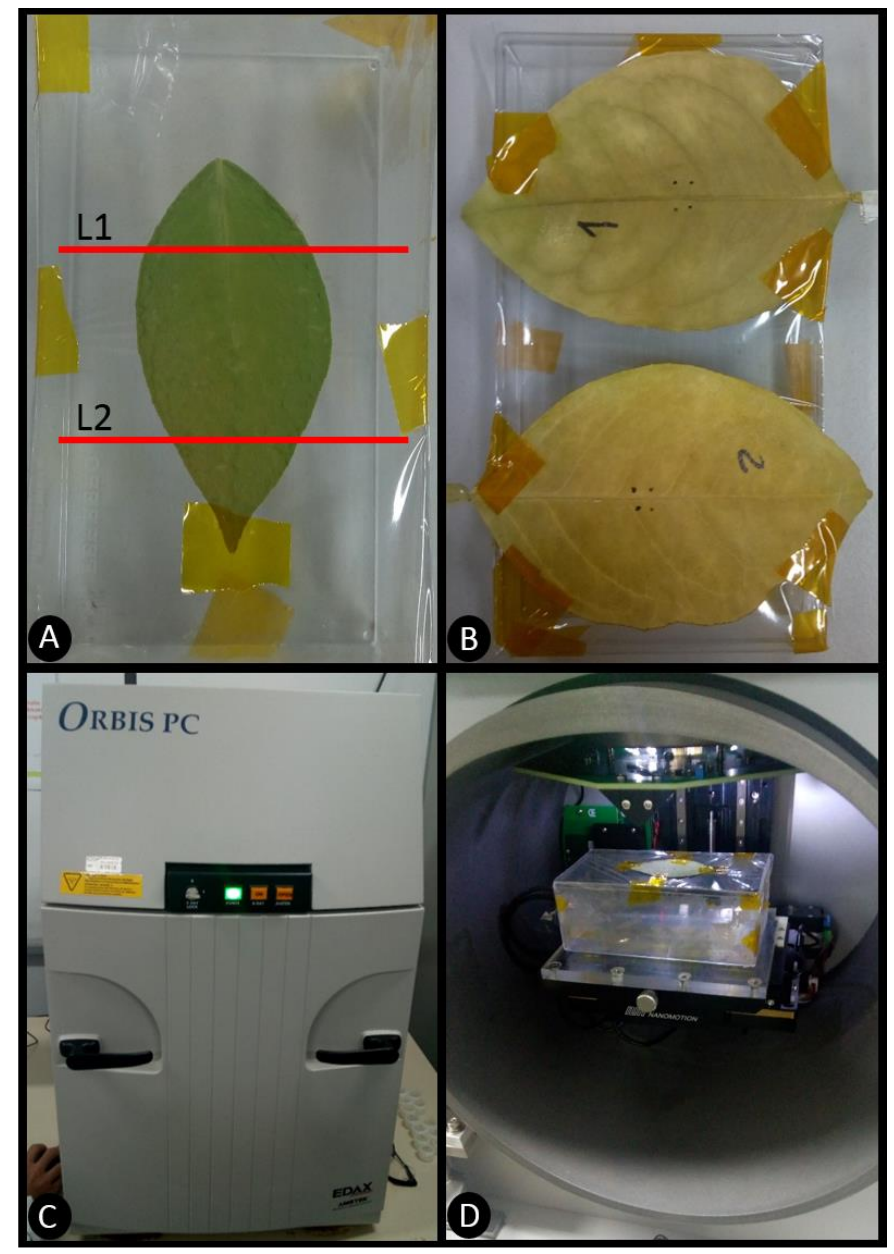

Figura 5. Folha de laranja 'Hamlin' não inoculada com CLas. (A) Destaque para as replicatas (linhas) de mapeamento onde foram realizadas as análises de distribuição espacial de nutrientes. (B) Folhas secas de laranja 'Hamlin' com HLB, 18 meses após a inoculação. (C e D) Espectrômetro de fluorescência de raios X com feixe micrométrico ( $\mu$-XRF, Orbis PC, EDAX, EUA).

Para distinguir os sinais elementares do ruído do equipamento foram considerados apenas os valores acima do limite de identificação (LI), calculado de acordo com a equação a seguir:

$$
\text { Eq.X: } L I=8,485 \sqrt{\frac{B G}{t}}
$$

Onde: BG: contagem por segundo (cps), é a média de dez leituras de ruído selecionada aleatoriamente em pontos da amostra; t: segundos (s), é o tempo de aquisição por ponto. Os valores abaixo do LI foram considerados iguais a zero.

Após a leitura das amostras pelo equipamento de raio $\mathrm{X}$, os dados foram inseridos em planilhas de dados (Excel) e transferidos para o Software Origin 2019 para a análise, elaboração 
de gráficos e geração de imagens com a quantificação das intensidades dos elementos das linhas de mapeamento de cada folha analisada. Os resultados foram expressos em intensidades de cada elemento corrigidas e normalizadas pelo espalhamento Compton (COMPTON, 1923).

\subsection{Reação de plantas transgênicas de laranja doce à infecção por Xanthomonas citri subsp. citri}

Inoculação por aspersão

Em todos os bioensaios foram utilizados o isolado da bactéria Xanthomonas citri subsp. citri 306 contendo um gene marcador GFP expresso constitutivamente (referido como Xcc_GFP, fornecido por Adrian Alberto Vojnov, Instituto de Ciência e Tecnologia Dr. Cesar Milstein, Fundação Pablo Cassará, CONICET - Argentina; RIGANO et al., 2007) e cedido pela Dra. Juliana Freitas-Astúa.

A bactéria foi cultivada em meio de cultura NBY $\left(3 \mathrm{~g} \mathrm{~L}^{-1}\right.$ extrato de carne, $5 \mathrm{~g} \mathrm{~L}^{-1}$ peptona, $2 \mathrm{~g} \mathrm{~L}^{-1}$ extrato de levedura, $2 \mathrm{~g} \mathrm{~L}^{-1} \mathrm{~K}_{2} \mathrm{HPO}_{4}, 0,5 \mathrm{~g} \mathrm{~L}^{-1} \mathrm{KH}_{2} \mathrm{PO}_{4}$ e ágar) contendo ampicilina $100 \mu \mathrm{g} \mathrm{mL}^{-1}$, segundo as recomendações de Caserta et al. (2014), por 48 horas, entre 26 e $28{ }^{\circ} \mathrm{C}$. Para o preparo do inóculo, a bactéria foi diluída em uma solução tampão fosfatosalino (PBS ou phosphate buffered saline). Três ensaios independentes foram realizados (05/04/2017, 01/11/2017 e 02/02/2018). Nestes ensaios, todos os eventos expressando os genes csdl ou $d 4 e 1$, conforme descritos no subitem 3.4., foram desafiados com Xcc. Todas as plantas de laranja 'Hamlin' foram podadas a 1/3 do ápice, 35 dias antes das inoculações, para a obtenção de folhas homogêneas, sadias e imaturas (75\% da completa expansão foliar) (GOTTWALD; GRAHAM, 1992).

A concentração da suspensão bacteriana foi ajustada para uma densidade de $10^{8}$ UFC $\mathrm{ml}^{-1}$ (unidades formadoras de colônia), em espectrofotômetro a $600 \mathrm{~nm}(\mathrm{OD}=0,3)$. Diluições seriadas em tampão fosfato (PBS) foram realizadas para a obtenção da concentração final de $10^{6} \mathrm{UFC} \mathrm{mL}^{-1}$. A inoculação foi realizada por aspersão, nos três ensaios, com o auxílio de um pulverizador manual de pressão prévia de $2 \mathrm{~L}$, até o ponto de escorrimento em todas as folhas das plantas. Durante os experimentos, as plantas foram mantidas em casa de vegetação, sob temperaturas $\left(25^{\circ} \mathrm{C}\right.$ a $\left.30{ }^{\circ} \mathrm{C}\right)$ e umidade relativa $(65 \%$ a $80 \%)$. 
Avaliações de severidade e incidência da doença foram realizadas em todos os genótipos, nos três experimentos independentes. A quantificação da severidade foi realizada semanalmente, até 35 dias após a inoculação (DAI), de acordo com a escala diagramática de notas (0 a $16 \%$ ) para a avaliação de cancro cítrico (BELASQUE JR et al., 2005). A incidência da doença foi calculada pela porcentagem de folhas com sintomas em relação à quantidade total de folhas da planta. A severidade foi avaliada pela porcentagem de área foliar com lesões, a partir de material de 12 plantas de cada tratamento e, posteriormente, comparadas com a severidade de cancro cítrico em plantas não transgênicas.

Após realizar as avaliações de incidência e severidade nos três experimentos, calculouse a área abaixo da curva de progresso da doença (AACPD) para a determinação dos genótipos mais resistentes ao cancro cítrico. A AACPD foi calculada através da integração trapezoidal seguindo a fórmula (SHANER; FINNEY, 1977):

$$
\operatorname{AACPD}=\sum_{i=1}^{\mathrm{n}-1}\left[\left(\left(\mathrm{X}_{1}+\mathrm{X}_{2}\right) / 2\right) \cdot\left(\mathrm{t}_{2}-\mathrm{t}_{1}\right)\right]
$$

Onde: X é a severidade ou incidência da doença, em porcentagem, de duas avaliações consecutivas, t é o tempo, em dias entre as avaliações, e n é o número total de avaliações.

Os resultados obtidos representam o aumento médio diário de incidência e severidade de cancro cítrico da área abaixo da curva padronizada no tempo avaliado. Os resultados foram submetidos à análise de variância utilizando-se o software $\mathrm{SAS}^{\circledR}$ e as médias dos eventos transgênicos comparadas com a médias das plantas não transgênicas pelo teste de Dunnett $(P<0,05)$.

\section{Inoculação por ferimentos}

A determinação da suscetibilidade de genótipos à infecção por Xcc é mais efetiva quando se utiliza a técnica de inoculação por ferimentos em folhas de citros, comparando-se a outros métodos (BELASQUE JR et al., 2008; GRAHAM; GOTTWALD, 1990). Por isso, sete eventos-elite foram selecionados de acordo com os melhores resultados de resistência à Xcc obtidos nos três experimentos por aspersão, conforme detalhados no item anterior, para serem incluídos em experimentos de desafio à Xcc por meio de inoculação por ferimentos. Os eventos de laranjas doces transgênicas selecionados (eventos-elite) (csd1: TG4-3; TG4-4; TG4-6; TG49; d4e1: HS-9; HS-11; HS-33), dois tratamentos de laranjas doces não transgênicas 
(Testemunha 1 e Testemunha 2) e plantas contendo vetor vazio (V1) foram utilizados para a realização de novas avaliações de resistência à Xcc.

A quantificação da população bacteriana foi avaliada através da inoculação por ferimentos em folhas de laranjeiras utilizando-se uma agulha histológica $(0,55 \mathrm{~mm}$ x 0,20 mm) imersa em suspensão bacteriana cultivada em meio de cultura NBY, ajustada para uma densidade de $10^{8} \mathrm{UFC} \mathrm{ml}^{-1}(\mathrm{OD}=0,3)$ e diluída em tampão fosfato (PBS) para a obtenção da concentração final de $10^{6} \mathrm{UFC} \mathrm{mL}^{-1}$, conforme descrito anteriormente. Foram realizadas 20 perfurações (em cinco folhas) por planta de cada uma das 12 plantas provenientes de cada tratamento. A preparação do inóculo e a concentração da suspensão final também foram empregadas de acordo com a metodologia descrita anteriormente. Três ensaios independentes foram novamente realizados para estas avaliações. A primeira inoculação foi feita em 10/05/2018, a segunda em 10/08/2018 e a terceira em 11/02/2019.

O crescimento bacteriano foi avaliado através da coleta aleatória de três discos foliares perfurados a partir da área infiltrada pela inoculação (com um centímetro de diâmetro) de cada evento. Os discos coletados e mantidos em tubos plásticos de 1,5 $\mathrm{mL}$ foram macerados e homogeneizados com o auxílio de um pistilo em solução tampão fosfato (PBS) com $1 \mathrm{~mL}$ em cada tubo. Após esse procedimento, em cada dia avaliado, diluições em série foram realizadas, e $30 \mu \mathrm{L}$ da suspensão do macerado de cada evento foram distribuídos em três placas em meio de cultura NBY. As colônias de Xcc foram contadas 48 horas após incubação a $26-28{ }^{\circ} \mathrm{C}$, cujos valores foram utilizados para calcular o número de unidades formadoras de colônias presentes na amostra dos discos foliares de cada evento. As avaliações foram realizadas $0 ; 1 ; 3 ; 5 ; 8 ; 15$ e 21 dias após a inoculação (DAI) de cada experimento. Os resultados foram submetidos a análise de variância, utilizando-se o software $\mathrm{SAS}^{\circledR}$, e as médias entre os eventos comparadas pelo teste de Dunnett $(P<0,05)$. Os dados foram transformados em $\log _{10}$.

Adicionalmente, avaliações dos números de lesões, em 200 ferimentos, formadas de cancro cítrico foram realizadas aos $7 ; 14 ; 21 ; 28$ e 35 DAI nas mesmas plantas inoculadas por ferimentos através de agulhas histológicas. As áreas das lesões foram mensuradas, a partir de folhas destacadas, aos 35 DAI. Analisaram-se quatro lesões por folha, sendo avaliadas cinco folhas por planta. As avaliações da área da lesão foram realizadas com o auxílio do software de análises de imagens QUANT 1.0 (VALE et al., 2001). Os dados foram submetidos a análises de variância (ANOVA), utilizando o software $\mathrm{SAS}^{\circledR}$ e as médias entre os eventos pelo teste de Dunnett $(P<0,05)$. Este experimento foi realizado duas vezes. 


\subsubsection{Microscopia de epifluorescência}

Análises histopatológicas foram empregadas visando avaliar a interação e o colonização do patógeno no tecido vegetal dos diferentes tratamentos (eventos-elite) para as duas construções gênicas. As análises anatômicas foram realizadas no Laboratório de Anatomia Vegetal, do Departamento de Ciências Biológicas da ESALQ/USP. As análises das lesões foram realizadas a partir de inoculações por aspersão de $X c c_{-}$GFP em folhas de laranja doce apresentando a mesma metodologia descrita no subitem inoculação por aspersão.

\section{Detecção de Xcc}

Segmentos foliares frescos de, aproximadamente, $1 \mathrm{~cm}^{2}$ contendo lesões, de diferentes eventos transgênicos, foram coletados e seccionados transversalmente com espessuras de 25 $\mu$ m em micrótomo de deslize (Leica SM2000 R). Lâminas de vidro foram montadas, tratadas com tampão PBS (0,2 M - pH 7,2) e com o corante Calcofluor White que destaca as cadeias de celulose $\beta 1-4$ da parede celular, e submetidas a vácuo para remoção do ar dos espaços intercelulares. Esse procedimento foi repetido por três vezes em cada amostra, em ensaios histopatológicos de diferentes eventos, avaliadas até 35 DAI. As lâminas foram examinadas utilizando-se filtro GFP (excitação 470/40; emissão 525/50) no microscópio de epifluorescência Leica DM5000 B (Leica ${ }^{\mathrm{TM}}$, Wetzlar, Alemanha). Todas as imagens foram capturadas por um sistema de câmera de vídeo DFC365 FX (Leica ${ }^{\mathrm{TM}}$, Wetzlar, Alemanha) acoplado a um computador, utilizando-se o software Leica Application Suite (LAS AF).

\section{Deposição de calose}

A deposição de calose foi verificada em amostras de segmentos foliares de eventoselite contendo o gene $c s d l$ horas após a infecção de $X c c$. As análises de calose foram realizadas a partir de inoculações por ferimentos de $X c c_{-}$GFP em folhas de laranjeira doce apresentando a mesma metodologia descrita no subitem inoculação por ferimentos. O experimento foi repetido em cinco plantas diferentes de cada evento transgênico, utilizando-se quatro folhas por planta. As avaliações foram realizadas 24, 48 e 72 horas após a inoculação (h.a.i.). Em cada avaliação, discos foliares próximos do local da inoculação foram recolhidos e, em seguida, seções longitudinais e transversais de $25 \mu \mathrm{m}$ de espessura foram produzidas em micrótomo de deslize (Leica SM2000 R). Os cortes frescos foram corados com 1\% de azul de anilina (diluído em álcool a 70\%) por dez minutos e submetidos a vácuo, por 15 minutos. As amostras foram examinadas usando-se filtro A4 (excitação 340-380 nm, 450-490 nm) no microscópio de 
epifluorescência Leica DM5000 B (Leica ${ }^{\mathrm{TM}}$, Wetzlar, Alemanha). Todas as imagens foram capturadas por um sistema de câmera de vídeo DFC365 FX (Leica ${ }^{\mathrm{TM}}$, Wetzlar, Alemanha) acoplado a um computador, utilizando o software Leica Application Suite (LAS AF). A calose presente no tecido foliar de cada amostra foi analisada de forma qualitativa e comparada entre os eventos-elite transgênicos e não transgênicos.

\subsubsection{Quantificação de RNA mensageiro do gene $c s d 1$ em folhas de laranjeira doce após a infecção por $X c c$}

A quantificação da expressão do gene $c s d l$ foi realizada em plantas transgênicas e não transgênicas dos eventos-elite horas após a inoculação por Xcc, por RT-qPCR. A inoculação de $X c c$ foi realizada através de ferimentos por agulhas histológicas, em cinco folhas (quatro perfurações cada) por planta de cada evento-elite avaliado. A suspensão bacteriana foi cultivada em meio de cultura NBY, ajustada à densidade de $10^{8} \mathrm{UFC} \mathrm{ml}^{-1}(\mathrm{OD}=0,3)$ e diluída em tampão fosfato (PBS) para a obtenção da concentração final de $1,16 \times 10^{6} \mathrm{UFC} \mathrm{mL}^{-1}$, conforme procedimento descrito anteriormente.

Cada amostra foi composta por um pool de dez discos foliares de plantas diferentes de cada evento transgênico, utilizando-se um tubo plástico de $1,5 \mathrm{ml}$, com um centímetro de diâmetro. Os discos foliares foram coletados aleatoriamente 24, 48 e 72 horas após a inoculação (h.a.i.). A extração de RNA e a síntese de cDNA foram realizadas conforme metodologia descrita no item 3.2.2. Cada amostra foi analisada em três replicatas biológicas e duas replicatas técnicas, incluindo amostras de plantas não transgênicas, nas condições de amplificação padrão (FAST), realizada no equipamento 7500 FAST $^{\mathrm{TM}}$ Real-Time PCR System (Applied Biosystems, Foster City, USA). O valor do ciclo de quantificação $(\mathrm{Cq})$ foi determinado para o gene alvo csdl e para os dois genes de referência (UBC21 e DIMI) em cada amostra avaliada. O software LinRegPCR (RAMAKERS et al., 2003) foi utilizado para avaliar a eficiência de reação de cada gene. Após os cálculos da eficiência, os resultados foram analisados no software REST ${ }^{\circledR}$ (PFAFFL; HORGAN; DEMPFLE, 2002) e o cálculo da expressão gênica foi realizado utilizando-se o modo de quantificação relativa $(\Delta \Delta \mathrm{Cq})$. Os dados foram submetidos à análise de variância e as médias dos eventos transgênicos comparadas com a médias das plantas não transgênicas pelo teste de Dunnett $(P<0,05)$. Como calibrador foi utilizada a planta testemunha (não transgênica) de menor expressão. 


\subsubsection{Resposta antioxidativa isoenzimática}

A quantificação das atividades isoenzimáticas em resposta a explosão oxidativa foram avaliadas durante o processo infeccioso de Xcc em plantas cítricas, tornando-as uma importante ferramenta na compreensão da interação planta-patógeno. Todas as análises isoenzimáticas foram realizadas no Laboratório de Genética e Bioquímica de Plantas do Departamento de Genética da ESALQ/USP.

Amostras de sete eventos-elite de laranja 'Hamlin' transgênicos (gene csd1: TG4-3; TG4-4; TG4-6; TG4-9; gene d4e1: HS-9; HS-11; HS-33) e dois tratamentos de laranjas doces não transgênicas (Testemunha 1 e Testemunha 2) foram selecionados para quantificações do acúmulo de peróxido de hidrogênio e de atividades isoenzimáticas a 0, 24, 48 e 72 horas após a inoculação por Xcc. A inoculação da bactéria foi feita através de ferimentos por agulhas histológicas, em cinco folhas por planta (quatro perfurações cada folha) de cada uma das 12 repetições dos eventos-elite avaliados e também nas plantas não transgênicas. A suspensão bacteriana foi preparada de acordo com a metodologia apresentada no subitem inoculação por ferimentos. Os resultados destes experimentos foram submetidos a análise de variância e as médias dos eventos transgênicos comparadas com a médias das plantas não transgênicas pelo teste de Dunnett $(P<0,05)$.

Peroxidação lipídica e quantificação de peróxido de hidrogênio $\left(\mathrm{H}_{2} \mathrm{O}_{2}\right)$

O processo de peroxidação lipídica desencadeia a produção de malondialdeído (MDA), sendo que a concentração deste composto orgânico pode ser um importante parâmetro para mensurar o nível de estresse oxidativo em tecidos vegetais (MENG et al., 2009; LOPEZMARTINEZ et al., 2009).

A peroxidação lipídica foi avaliada através do conteúdo de substâncias reativas ao ácido tiobarbitúrico (TBARS), segundo a metodologia de Heath e Packer (1968). Tecidos foliares $(200 \mathrm{mg}$ ) da região de inoculação foram coletados, macerados e adicionados $500 \mu \mathrm{L}$ de ácido tricloroacético (TCA) a $0,1 \%$. As amostras foram centrifugadas por dez minutos, em $15.000 \mathrm{rpm}$, a $4{ }^{\circ} \mathrm{C}$. O sobrenadante foi coletado $(500 \mu \mathrm{L})$ em tubos Eppendorf ${ }^{\circledR}$, e $1,5 \mathrm{ml} \mathrm{de}$ 0,5\% TBA diluído em $20 \%$ de TCA foi adicionado. As amostras foram incubadas em banhomaria a $95{ }^{\circ} \mathrm{C}$ por 30 minutos. As leituras das absorbâncias das amostras foram realizadas nos comprimentos de onda de $535 \mathrm{~nm}$ e $600 \mathrm{~nm}$ em espectrofotômetro (Genesys ${ }^{\mathrm{TM}}$ 10S UV-Vis). A concentração de equivalentes em malondialdeído (MDA) foi calculada por meio de um 
coeficiente de extinção de $\varepsilon^{\mathrm{M}}=155 \mathrm{mM}^{-1} \mathrm{~cm}^{-1}$, apresentando resultados em $\eta$ mols MDA g ${ }^{-1}$ MF (HEATH; PACKER, 1968).

A determinação do conteúdo de peróxido de hidrogênio foi realizada de acordo a metodologia de Alexieva et al. (2001). Tecidos vegetais (200 mg) de cada amostra foram macerados, em banho de gelo, com 2 mL de TCA 0,1\%, contendo, aproximadamente, $20 \%$ de polivinilpolipirrolidona (PVPP). Após a homogeneização, o conteúdo foi transferido para tubos de $2 \mathrm{~mL}$ e centrifugado por dez minutos a $13.000 \mathrm{rpm}$, a $4{ }^{\circ} \mathrm{C}$. O sobrenadante $(200 \mu \mathrm{L})$ das amostras foi retirado e adicionado a uma mistura de reação contendo $200 \mu \mathrm{L}$ de tampão fosfato $100 \mathrm{mM}(\mathrm{pH} 7,5)$ e $800 \mu \mathrm{L}$ de iodeto de potássio $1 \mathrm{M}$. As amostras foram incubadas em gelo por uma hora no escuro e as leituras das absorbâncias foram realizadas em triplicatas no comprimento de onda de $390 \mathrm{~nm}$ em espectrofotômetro. A quantidade de peróxido de hidrogênio de cada amostra foi calculada através da construção de uma curva padrão com concentrações conhecidas de $\mathrm{H}_{2} \mathrm{O}_{2}$ e expressas em $\mu$ Molar $\mathrm{g}^{-1} \mathrm{MF}$.

Localização do acúmulo de peróxido de hidrogênio $\left(\mathrm{H}_{2} \mathrm{O}_{2}\right)$

$\mathrm{O}$ acúmulo in situ de $\mathrm{H}_{2} \mathrm{O}_{2}$ no local de inoculação de $X c c$ foi detectado por coloração histoquímica utilizando-se o reagente 3,3'-diaminobenzidina (DAB), conforme metodologia descrita por Shi et al. (2010). Os discos foliares dos eventos-elite foram coletados próximos ao local de inoculação, por ferimento, e mantidos incubados no escuro por 24 horas em tubos cônicos contendo $50 \mathrm{~mL}$ de tampão Tris $(10 \mathrm{mM}, \mathrm{KCl} 50 \mathrm{mM}, \mathrm{pH}$ 6,1) com 0,05 g de DAB ( $\mathrm{pH}$ da solução corrigido para $\mathrm{pH} 3,8$ ). As avaliações foram realizadas em amostras de folhas transgênicas e não transgênicas a $0 ; 12 ; 24 ; 48$ horas após a inoculação com Xcc. Os discos foliares corados com DAB foram fotografados com o auxílio de uma câmera digital (Nikon $\left.\mathrm{D} 100^{\circledR}\right)$.

\section{Extração e determinação de proteína}

Amostras foliares de cada tratamento foram coletadas, transferidas para um cadinho com nitrogênio líquido, e depois maceradas com tampão de extração fosfato de potássio 100 $\mathrm{mM}$ pH 7,5 (1 g de tecido vegetal/3 ml de tampão), contendo $1 \mathrm{mM}$ de ácido etilenodiamino tetracético (EDTA), 3 mM de ditiotreitol (DTT) e 4\% (p/v) de PVPP (AZEVEDO et al., 1998). O homogeneizado foi centrifugado a $10.000 \mathrm{rpm}$, por 30 minutos a $4{ }^{\circ} \mathrm{C}$ e o sobrenadante foi armazenado a $-80^{\circ} \mathrm{C}$ divididos em alíquotas até o momento das análises de SOD, CAT e GPX. 
A concentração de proteína total nas amostras foi determinada pelo método de Bradford (1976), utilizando-se a albumina de soro bovino (BSA) como padrão.

\section{Determinação de atividades de isoenzimas antioxidantes}

A atividade da superóxido dismutase (SOD) foi determinada de acordo com a metodologia de Giannopolitis e Ries (1977) e Cembrowska-Lech et al. (2015). A reação foi conduzida em uma câmara de reação, sob iluminação de lâmpada fluorescente a $25^{\circ} \mathrm{C}$. As amostras, previamente coletadas, foram descongeladas e adicionadas em um meio de reação contendo tampão fosfato de potássio $50 \mathrm{mM}(\mathrm{pH} 7,8), 50 \mathrm{mM}$ de metionina, $1 \mathrm{mM}$ nitrobluetetrazólio (NBT), $10 \mathrm{mM}$ de ácido etilenodiamino tetracético (EDTA) e 0,12 mM de riboflavina, totalizando $1,5 \mathrm{~mL}$ de reação. Os tubos com a solução foram misturados e colocados no interior da câmara no escuro. Após cinco minutos acendeu-se a luz do interior da caixa por cinco minutos, e o composto blue formazana foi produzido pela fotorreação do NBT. As leituras foram realizadas em triplicatas, no comprimento de onda de $560 \mathrm{~nm}$ em

espectrofotômetro (Genesys ${ }^{\mathrm{TM}}$ 10S UV-Vis). Uma unidade de SOD foi definida como a atividade enzimática necessária para inibir $50 \%$ da fotorredução do NBT para formazana. A atividade foi expressa como Unidades SOD mg${ }^{-1}$ de proteína $\min ^{-1}$.

Eletroforese em gel de poliacrilamida não-desnaturante (PAGE) e revelação de gel de SOD

Os experimentos de eletroforese (cuba vertical) em sistemas de tampão descontínuos e não-desnaturantes (gel de resolução de 10\%; gel de empilhamento de 2,5\%) foram realizados utilizando-se o sistema mini gel no tamanho de $8,3 \mathrm{~cm}$ x $10,2 \mathrm{~cm}$ na concentração ideal de poliacrilamida (12\%) para as proteínas de SOD, conforme descrito por Laemmli (1970). As amostras foram submetidas a eletroforese, e a uma corrente constante de $30 \mathrm{~mA}, 100 \mathrm{~V}$, a $4{ }^{\circ} \mathrm{C}$, em tempo médio de corrida de quatro horas.

Depois da eletroforese, os géis foram divididos verticalmente em três partes iguais. Em cada faixa, $150 \mu \mathrm{g}$ da proteína total foi carregada. A primeira parte foi revelada para a atividade de SOD. A segunda e a terceira parte foram incubadas por 30 minutos em $100 \mathrm{mM}$ de solução tampão fosfato de potássio $50 \mathrm{mM}$ (pH 7,8) contendo $2 \mathrm{mM}$ de $\mathrm{KCN}$ e $100 \mathrm{mM}$ de solução tampão fosfato de potássio $50 \mathrm{mM}(\mathrm{pH} 7,8)$ contendo $5 \mathrm{mM} \mathrm{de} \mathrm{H}_{2} \mathrm{O}_{2}$, respectivamente (AZEVEDO et al., 2003). Após essas etapas, ambas as partes foram lavadas e reveladas para a atividade de SOD. O pré-tratamento dos géis em $\mathrm{H}_{2} \mathrm{O}_{2}$ e $\mathrm{KCN}$ antes da revelação de superóxido dismutase permite a classificação das isoformas da SOD em Cu/Zn-SOD, Fe-SOD e Mn-SOD. 
A Cu/Zn-SOD é inibida por ambos os inibidores; a Fe-SOD é resistente ao KCN e inibida por $\mathrm{H}_{2} \mathrm{O}_{2}$; e Mn-SOD é resistente a ambos os inibidores (GIANNOPOLITIS; RIES, 1977).

Na revelação do gel de SOD para a determinação das isoformas, os géis foram lavados em água deionizada e incubadas no escuro em uma solução tampão de fosfato de potássio 50 $\mathrm{mM}$ (pH 7,8) contendo 2,45 mM de NBT, $1 \mathrm{mM}$ de EDTA, $28 \mathrm{mM}$ de riboflavina e $28 \mathrm{mM}$ de tetrametil etileno diamina (TEMED). Após 30 minutos, os géis foram novamente lavados com água deionizada e expostos à luz fluorescente para a revelação e determinação das isoformas de SOD. As bandas visíveis formadas ficam acromáticas e o gel adquire coloração roxa.

\section{Catalase}

A atividade da catalase (CAT) foi analisada em espectrofotômetro (Genesys ${ }^{\mathrm{TM}}$ 10S UV-Vis) como descrito por Azevedo et al. (1998). O ensaio enzimático foi realizado a $25^{\circ} \mathrm{C}$ em uma solução contendo $1 \mathrm{~mL}$ de tampão fosfato de potássio $100 \mathrm{mM}(\mathrm{pH}$ 7,5) acrescida de $25 \mu \mathrm{L}$ de $\mathrm{H}_{2} \mathrm{O}_{2}$ (solução a $30 \%$ ). A reação iniciou-se pela adição de $25 \mu \mathrm{L}$ de extrato proteico de cada amostra e a atividade foi determinada monitorando-se a decomposição de $\mathrm{H}_{2} \mathrm{O}_{2}$ a 240 $\mathrm{nm}$, durante o período de um minuto. As leituras foram realizadas em triplicatas e os resultados foram expressos em $\mu \mathrm{mol} \mathrm{min}^{-1} \mathrm{mg}^{-1}$ de proteína.

\section{Glutationa peroxidase}

A atividade da glutationa peroxidase foi determinada por espectofotômetro (Genesys ${ }^{\mathrm{TM}}$ 10S UV-Vis), de acordo com Azevedo et al. (1998). A atividade enzimática foi determinada a $37{ }^{\circ} \mathrm{C}$ em uma mistura constituída de $1 \mathrm{~mL}$ de tampão fosfato de potássio $100 \mathrm{mM}(\mathrm{pH} 7,5)$, contendo 10 mM de ácido 2-nitrobenzóico (GSH), GSSG 1 mM e 1,5 mM de NADPH. A reação foi iniciada pela adição de $1,5 \mathrm{mM}$ de NADPH e $1 \mathrm{mM}$ de $\mathrm{H}_{2} \mathrm{O}_{2}$, seguida pelo monitoramento do aumento da absorbância a $340 \mathrm{~nm}$ ao longo de dois minutos. A atividade de glutationa peroxidase foi expressa em $\mathrm{nmol} \mathrm{min}^{-1} \mathrm{mg}^{-1}$ de proteína.

\subsubsection{Atividade antimicrobiana in vitro}

A atividade antimicrobiana in vitro do extrato proteico de plantas matrizes (eventos transgênicos) de laranja 'Hamlin' transformadas com o gene que codifica o peptídeo antimicrobiano $(d 4 e 1)$ foi avaliada após a incubação com suspensão de Xcc. Extratos proteicos 
de cada evento transgênico (HS1; HS9; HS11; HS12; HS13; HS33; HS36; HS38; HS45; HS48), de plantas não transgênicas (Testemunha 1) e de Vetor vazio (V1) foram obtidos pela maceração de $200 \mathrm{mg}$ de tecido foliar em solução de tampão de extração fosfato de potássio $100 \mathrm{mM} \mathrm{pH}$ 7,5 (1 g de tecido vegetal/3 ml de tampão), contendo $1 \mathrm{mM}$ de ácido etilenodiamino tetracético (EDTA), 3 mM de ditiotreitol (DTT) e 4\% (p/v) de PVPP (AZEVEDO et al., 1998). O homogeneizado foi centrifugado a 10.000 rotações por minuto por 30 minutos a $4{ }^{\circ} \mathrm{C}$ e o sobrenadante foi coletado. A concentração de proteína total para todas as amostras foi determinada pelo método de Bradford (1976), utilizando-se a albumina de soro bovino (BSA) como padrão. Todas as amostras foram diluídas para uma concentração final de $100 \mu \mathrm{g} \mathrm{mL}^{-1}$.

Procedeu-se o cultivo dos isolados de Xcc em meio sólido NBY. Uma solução bacteriana a partir do cultivo desses isolados, contendo $1,17 \times 10^{6} \mathrm{UFC} \mathrm{mL}^{-1}, \mathrm{OD}=0,349$, foi preparada após 48 horas. Determinou-se a atividade antimicrobiana por meio de incubação de $900 \mu \mathrm{L}$ do extrato proteico e $100 \mu \mathrm{L}$ de suspensão bacteriana, por quatro horas, sob agitação, a $120 \mathrm{rpm}$, conforme metodologia adaptada de Osusky et al. (2005). A contagem de colônias de cada evento transgênico e também das plantas não transgênicas foi realizada após o plaqueamento e incubação por 48 horas, a $28^{\circ} \mathrm{C}$. As análises foram realizadas em triplicadas biológicas. Foi realizada uma incubação controle contendo apenas água. Os resultados foram submetidos a análise de variância e as médias dos eventos transgênicos comparadas com a médias das plantas não transgênicas pelo teste de Dunnett $(P<0,05)$. 


\section{RESULTADOS}

\subsection{Caracterização molecular dos eventos transgênicos expressando o gene csd1}

A análise de RT-qPCR foi realizada em 18 plantas matrizes de laranja 'Hamlin'. As plantas transgênicas utilizadas foram previamente analisadas por Southern blot, em trabalhos anteriores, que continham de uma a duas inserções do transgene no genoma da planta (MORAES, 2015). Considerando-se que o gene $c s d l$ é endógeno às plantas de laranja doce, os valores observados do nível de mRNA referem-se à somatória dos transcritos do transgene e do gene endógeno.

Os valores de expressão relativa do gene $\operatorname{csdl}$ das amostras variaram de 0,72 a 12,36. A expressão entre as plantas não transgênicas (T1, T2, T3) variou de 1 a 2,22, e entre as plantas transgênicas a variação foi de 2,26 a 12,36. Entre as plantas transgênicas contendo o vetor vazio (V1, V2) a variação foi de 0,72 a 1,91 (Figura 6). Todos os eventos transgênicos apresentaram diferenças significativas em relação ao nível de transcrição da planta não transgênica (T1), de acordo com as análises obtidas pelo software REST ${ }^{\circledR}$.

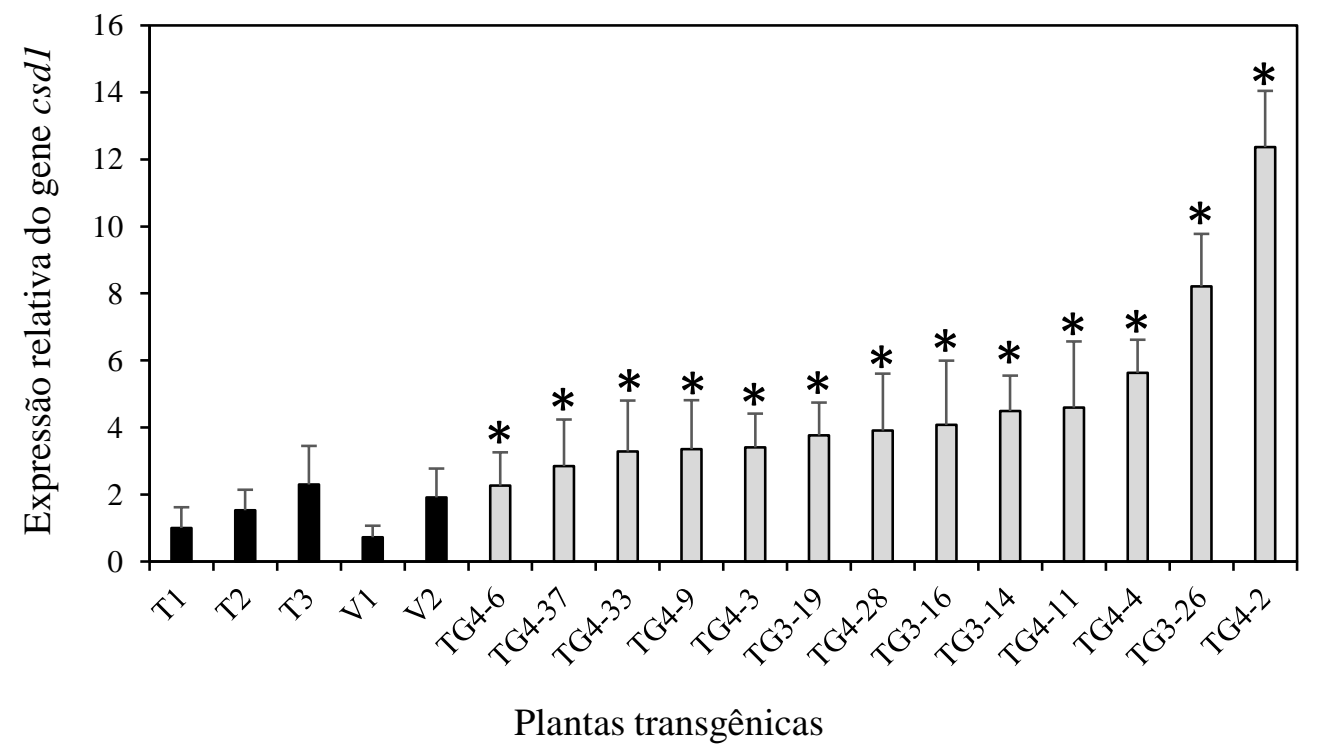

Figura 6. Expressão relativa do gene $c s d 1$ em relação aos genes de referência $U B C 21$ e $D I M 1$ em plantas de laranja 'Hamlin', expressando a construção gênica pCAMBIA2301-csd1. Os resultados obtidos dos eventos transgênicos foram comparados com o nível de transcrição da planta não transgênica (Testemunha - T1), utilizada como calibrador. *Difere significativamente em relação à média de $(\mathrm{T} 1)$, pelo teste de Dunnett $(P<0,05)$. As barras indicam o desvio padrão das médias. 
O nível de expressão do gene $\operatorname{csdl}$ do evento transgênico TG4-2 foi 12 vezes maior em comparação com a expressão gênica de plantas não transgênicas, indicando uma superexpressão deste gene relacionado à ativação do sistema de defesa de plantas contra o estresse oxidativo. As expressões gênicas entre os eventos transgênicos analisados apresentaram altas variações dos resultados, indicando que não houve correlação entre o número de inserções do transgene no genoma das plantas com os respectivos valores de quantificação relativa.

\subsection{Reação de plantas transgênicas de laranja doce à infecção por CLas}

\section{Detecção e quantificação de CLas}

As plantas transgênicas de laranja 'Hamlin' expressando o gene csdl ou $d 4 e 1$ utilizadas nesta pesquisa apresentaram desenvolvimento e fenótipo normais durante toda a condução do experimento, semelhantes aos observados em plantas não transgênicas. A quantificação da multiplicação e concentração de CLas nas plantas cítricas foram mensuradas em três períodos, aos seis, 12 e 18 meses após a inoculação (m.a.i.). Em todas as avaliações verificou-se alta eficiência de transmissão de CLas pelo método de enxertia por borbulhões infectados, obtidos por análise de qPCR. Seis meses após a inoculação, 84\% das plantas apresentaram resultados positivos para a presença de CLas, aos 12 m.a.i., detectou-se $C$ Las em 96\% das plantas inoculadas, e aos 18 m.a.i. 100\% das plantas inoculadas, transgênicas e não transgênicas, estavam infectadas pela bactéria.

Os primeiros sintomas visuais de HLB e o aparecimento de deficiências nutricionais foliares generalizadas foram observados em plantas não transgênicas, quatro meses após a inoculação. Nos eventos transgênicos expressando o gene csdl (TG3-16; TG4-2 e TG4-3) ou o gene $d 4 e 1$ (HS11 e HS33), os primeiros sintomas da doença surgiram somente aos nove meses após a inoculação (Figura 7). Nos demais eventos transgênicos, os sintomas relacionados ao HLB e as deficiências nutricionais, principalmente de manganês e zinco, foram observados seis meses após a inoculação (Figura 7). A intensidade dos sintomas de HLB presentes nas folhas de laranja 'Hamlin' não transgênicas avaliadas corroboram os resultados de detecção e quantificação de CLas, obtidos por qPCR para a maioria das plantas analisadas. 

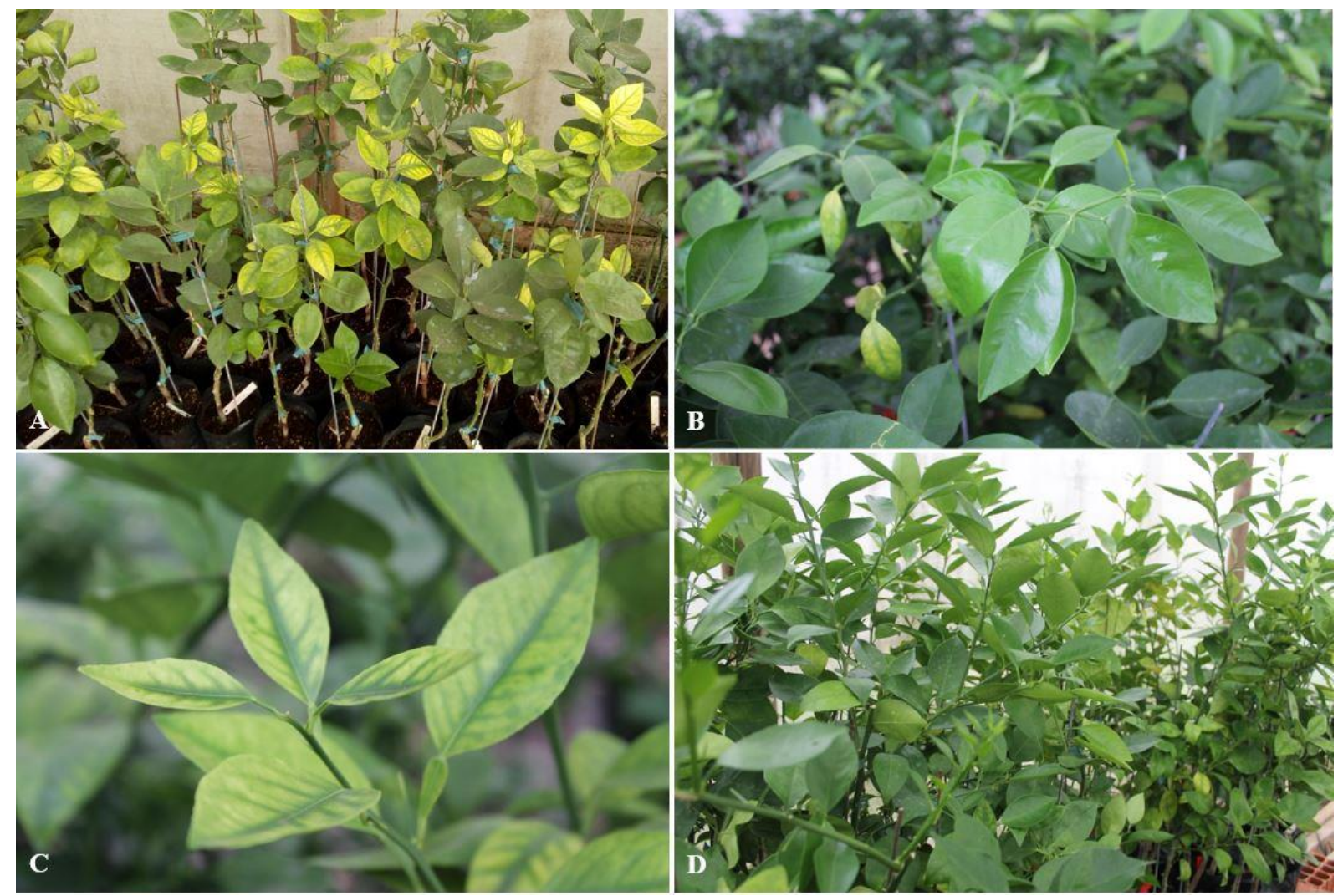

Figura 7. Sintomas foliares de HLB em plantas de laranja 'Hamlin', seis meses após a inoculação. (A) Amarelecimento foliar e mosqueado observados em plantas não transgênicas (T1). (B) Plantas transgênicas de laranja 'Hamlin' (evento TG3-16, gene csdl) sem sintomas de HLB. (C) Sintomas normalmente associados a deficiências nutricionais de manganês ou zinco em folhas de laranja 'Hamlin' não transgênica (T1). (D) Sintomas leves de HLB em folhas de laranja 'Hamlin' transgênica (evento TG4-9, gene csdl), em Piracicaba, SP.

A quantificação de CLas em cada amostra de DNA extraído das plantas transgênicas e não transgênicas foi realizada em duplicatas técnicas nos três períodos avaliados. Entre as réplicas amostradas houve um baixo coeficiente de variação de Ciclo threshold $(\mathrm{Ct})$ (máximo de $0,82 \%$ ), nos três períodos avaliados, indicando alta representatividade dos resultados obtidos (Tabela 2). Por outro lado, os valores de Ct obtidos entre os períodos avaliados mostraram altas variações (1,89\% a 19,29\%) (Tabela 2). A quantificação em número de cópias foi obtida através da construção de curva padrão, a partir de diluições seriadas de DNA plasmidial original, e os valores das concentrações conhecidas de DNA foram estimados de acordo com a equação de regressão linear $\left(y=-3,6223 x+18,02 ; R^{2}=0,9911\right)$. 
Tabela 2. Amplificação de DNA por qPCR e número de cópias (NC) da sequência 16S rDNA bacteriano em plantas transgênicas e não transgênicas de laranja 'Hamlin' infectadas por CLas.

\begin{tabular}{|c|c|c|c|c|c|c|c|}
\hline & \multirow{2}{*}{ Tratamentos } & \multicolumn{3}{|c|}{ Média dos valores de $\mathbf{C t}$} & \multicolumn{3}{|c|}{$\begin{array}{c}\text { População bacteriana } \\
\left.\text { (NC de } C \text { Las } \mu \mathrm{L}^{-1}\right)\end{array}$} \\
\hline & & 6 m.a.i. & 12 m.a.i. & 18 m.a.i. & 6 m.a.i. & 12 m.a.i. & 18 m.a.i. \\
\hline \multirow{12}{*}{ 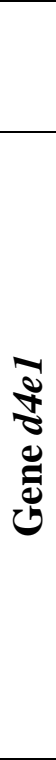 } & Testemunha 1 & 24,22 & 24,43 & 24,68 & $4,89 \times 10^{6}$ & $4,28 \times 10^{6}$ & $3,83 \times 10^{6}$ \\
\hline & Vetor vazio 1 & 25,65 & 25,10 & 25,07 & $1,98 \times 10^{6}$ & $2,80 \times 10^{6}$ & $2,87 \times 10^{6}$ \\
\hline & HS1 & 25,93 & 27,06 & 28,02 & $1,65 \times 10^{6}$ & $8,05 \times 10^{5}$ & $4,37 \times 10^{5}$ \\
\hline & HS9 & 27,69 & 26,53 & 26,61 & $5,40 \times 10^{5}$ & $1,13 \times 10^{6}$ & $1,07 \times 10^{6}$ \\
\hline & HS11 & $33,01 *$ & 28,61 & 27,68 & $1,82 \times 10^{4 *}$ & $3,00 \times 10^{5}$ & $5,42 \times 10^{5}$ \\
\hline & HS12 & 26,60 & 29,48 & 29,85 & $1,08 \times 10^{6}$ & $1,73 \times 10^{5}$ & $1,37 \times 10^{5}$ \\
\hline & HS13 & 30,21 & 26,68 & 27,33 & $1,09 \times 10^{5}$ & $1,02 \times 10^{6}$ & $6,77 \times 10^{5}$ \\
\hline & HS33 & 27,71 & 28,25 & 28,49 & $5,31 \times 10^{5}$ & $3,79 \times 10^{5}$ & $3,24 \times 10^{5}$ \\
\hline & HS36 & 28,80 & 25,76 & 25,96 & $2,66 \times 10^{5}$ & $1,83 \times 10^{6}$ & $1,62 \times 10^{6}$ \\
\hline & HS38 & 27,37 & 27,99 & 28,33 & $6,57 \times 10^{5}$ & $4,55 \times 10^{5}$ & $3,60 \times 10^{5}$ \\
\hline & HS45 & 26,55 & 26,51 & 26,24 & $1,11 \times 10^{6}$ & $1,14 \times 10^{6}$ & $1,35 \times 10^{6}$ \\
\hline & HS48 & 28,11 & 27,51 & 27,66 & $4,13 \times 10^{5}$ & $6,03 \times 10^{5}$ & $5,48 \times 10^{5}$ \\
\hline \multirow{14}{*}{ 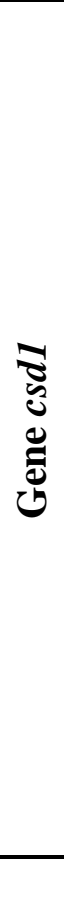 } & TG3-14 & 27,99 & 28,79 & 28,01 & $4,46 \times 10^{5}$ & $2,67 \times 10^{5}$ & $4,40 \times 10^{5}$ \\
\hline & TG3-16 & $31,24^{*}$ & 26,96 & 27,60 & $5,64 \times 10^{4 *}$ & $8,58 \times 10^{5}$ & $5,69 \times 10^{5}$ \\
\hline & TG3-19 & 29,66 & 26,24 & 24,87 & $1,54 \times 10^{5}$ & $1,36 \times 10^{6}$ & $3,23 \times 10^{6}$ \\
\hline & TG3-26 & 29,54 & 27,50 & 27,74 & $1,66 \times 10^{5}$ & $6,07 \times 10^{5}$ & $5,21 \times 10^{5}$ \\
\hline & TG4-2 & $30,56^{*}$ & 28,31 & 28,52 & $8,70 \times 10^{4 *}$ & $3,63 \times 10^{5}$ & $3,18 \times 10^{5}$ \\
\hline & TG4-3 & $30,10^{*}$ & 27,03 & 26,72 & $1,16 \times 10^{5}$ & $8,21 \times 10^{5}$ & $9,95 \times 10^{5}$ \\
\hline & TG4-4 & 28,01 & 26,02 & 26,97 & $4,39 \times 10^{5}$ & $1,66 \times 10^{6}$ & $8,51 \times 10^{5}$ \\
\hline & TG4-6 & 26,81 & 27,39 & 26,03 & $9,41 \times 10^{5}$ & $6,52 \times 10^{5}$ & $1,54 \times 10^{6}$ \\
\hline & TG4-9 & 26,11 & 26,86 & 27,58 & $1,47 \times 10^{6}$ & $9,14 \times 10^{5}$ & $5,77 \times 10^{5}$ \\
\hline & TG4-11 & 27,54 & 28,42 & 28,50 & $5,94 \times 10^{5}$ & $3,39 \times 10^{5}$ & $3,23 \times 10^{5}$ \\
\hline & TG4-28 & $29,80^{*}$ & 28,51 & 28,66 & $1,41 \times 10^{5}$ & $3,21 \times 10^{5}$ & $2,91 \times 10^{5}$ \\
\hline & TG4-33 & 27,92 & 28,87 & 25,08 & $4,67 \times 10^{5}$ & $2,55 \times 10^{5}$ & $2,84 \times 10^{6}$ \\
\hline & TG4-37 & $29,89 *$ & 27,38 & 26,96 & $1,33 \times 10^{5}$ & $6,55 \times 10^{5}$ & $8,59 \times 10^{5}$ \\
\hline & C.V. & 12,17 & 12,01 & 12,14 & 133,5 & 103,01 & 127,51 \\
\hline
\end{tabular}

Ct: média dos valores obtidos do Ciclo threshold de oito repetições de cada tratamento, em três avaliações independentes. m.a.i.: meses após a inoculação. *Difere significativamente em relação a média das plantas não transgênicas (Testemunha 1), pelo teste de Dunnett $(P<0,05)$. Número de cópias (NC) de CLas baseado na sequência $16 \mathrm{~S}$ rDNA. Valores estimados de acordo com as concentrações conhecidas de DNA, segundo a equação $\left(y=-3,6223 x+18,02 ; R^{2}=0,9911\right)$ da curva padrão. 
Até dezoito meses após a inoculação, as médias dos valores de $\mathrm{Ct}$ das plantas não transgênicas apresentaram-se constantes e inferiores em relação às médias dos valores de Ct de todos os eventos transgênicos, e variando entre 24,22 e 24,68 (Tabela 2). Portanto, as populações bacterianas das plantas não transgênicas também foram superiores às registradas nos eventos transgênicos em todos os períodos avaliados, apresentando concentrações máximas que variaram de 4,89 x $10^{6}$ a 3,83 x $10^{6} \mathrm{NC}$ de $C \operatorname{Las}_{\mu L^{-1}}$ (Testemunha 1 - não transgênica). Seis eventos transgênicos (TG3-16; TG4-2; TG4-3; TG4-28; HS11) apresentaram médias dos valores de Ct significativamente inferiores em relação ao Ct das plantas não transgênicas, seis meses após a inoculação. Por outro lado, na avaliação da população bacteriana neste mesmo período, ou seja, seis m.a.i., apenas dois eventos transgênicos expressando o gene csdl (TG316; TG4-2) e outro, expressando o gene $d 4 e 1$ (HS11) exibiram reduções significativas (5,64 x $10^{4} ; 8,70 \times 10^{4} ; 1,82 \times 10^{4} \mathrm{NC}_{\mu \mathrm{L}^{-1}}$, respectivamente), quando comparadas com as plantas não transgênicas.

Doze meses após a inoculação com CLas, a maioria dos eventos transgênicos apresentaram populações bacterianas mais altas do que as registradas na primeira avaliação; entretanto, sem diferenças significativas em relação às plantas não transgênicas (Tabela 2). Embora as plantas não transgênicas tenham apresentado sintomas visuais mais intensos de HLB, não foram observadas alterações significativas na concentração bacteriana destas amostras após o surgimento dos primeiros sintomas foliares ao longo dos períodos avaliados. Apesar de todos os eventos transgênicos apresentarem populações bacterianas inferiores em relação às plantas testemunhas (não transgênicas) analisadas nas três avaliações, não foram observadas diferenças significativas em nenhum evento transgênico, a partir de 12 m.a.i. de CLas. Variações das concentrações de CLas foram observadas entre os eventos transgênicos em relação à resposta à infecção, principalmente, entre a primeira e a última avaliação realizada, sugerindo que esses eventos pudessem retardar o crescimento da população bacteriana no tecido vegetal.

\section{Detecção de calose}

Amostras de segmentos foliares de plantas inoculadas e não inoculadas com CLas foram coletadas, analisadas e comparadas, qualitativamente, em relação as alterações de deposição de calose nos elementos de tubo crivado dos tecidos vegetais. As amostras de folhas dos eventos transgênicos que apresentaram menores títulos bacterianos, expressando o gene csd1 (TG3-16; TG4-2; TG4-28) ou d4e1 (HS11; HS12) e amostras de folhas de plantas não 
transgênicas (Testemunha 1 - T1) foram avaliadas 18 m.a.i.. As folhas de laranjeiras doces não inoculadas exibiram pequenas e isoladas deposições de calose (Figura 8A), enquanto as folhas de plantas infectadas apresentaram grandes acúmulos de calose no floema. Análises anatômicas de epifluorescência revelaram alta deposição de calose nos elementos de tubo crivado dos pecíolos foliares de eventos transgênicos inoculados com CLas (Figura 8K), em comparação com as plantas testemunhas (não transgênicas) inoculadas (Figura 8E). Entre as plantas transgênicas avaliadas, amostras dos eventos TG4-2 (gene csdl) e TG4-28 (gene csdl) indicaram elevadas deposições de calose em relação às dos demais eventos transgênicos. Esses resultados corroboram trabalhos anteriores que mostram que a deposição de calose pode ser uma importante resposta de defesa de plantas ao estresse biótico, resultando em menores populações de CLas.

Os resultados reportados nesta pesquisa revelam, portanto, uma maior deposição de calose no floema em amostras de alguns eventos transgênicos em comparação com aquelas de plantas não transgênicas, as quais também apresentaram maiores populações bacterianas, 18 m.a.i.. Apesar dos recentes progressos na busca de maior conhecimento acerca do patossistema HLB em espécies cítricas, ainda não há um modelo consolidado que explique a relação da evolução da doença com os efeitos desencadeados pelo patógeno no metabolismo vegetal e respectivos sintomas, em especial, o real significado da deposição de calose e sua relação com os mecanismos de defesa da planta. 

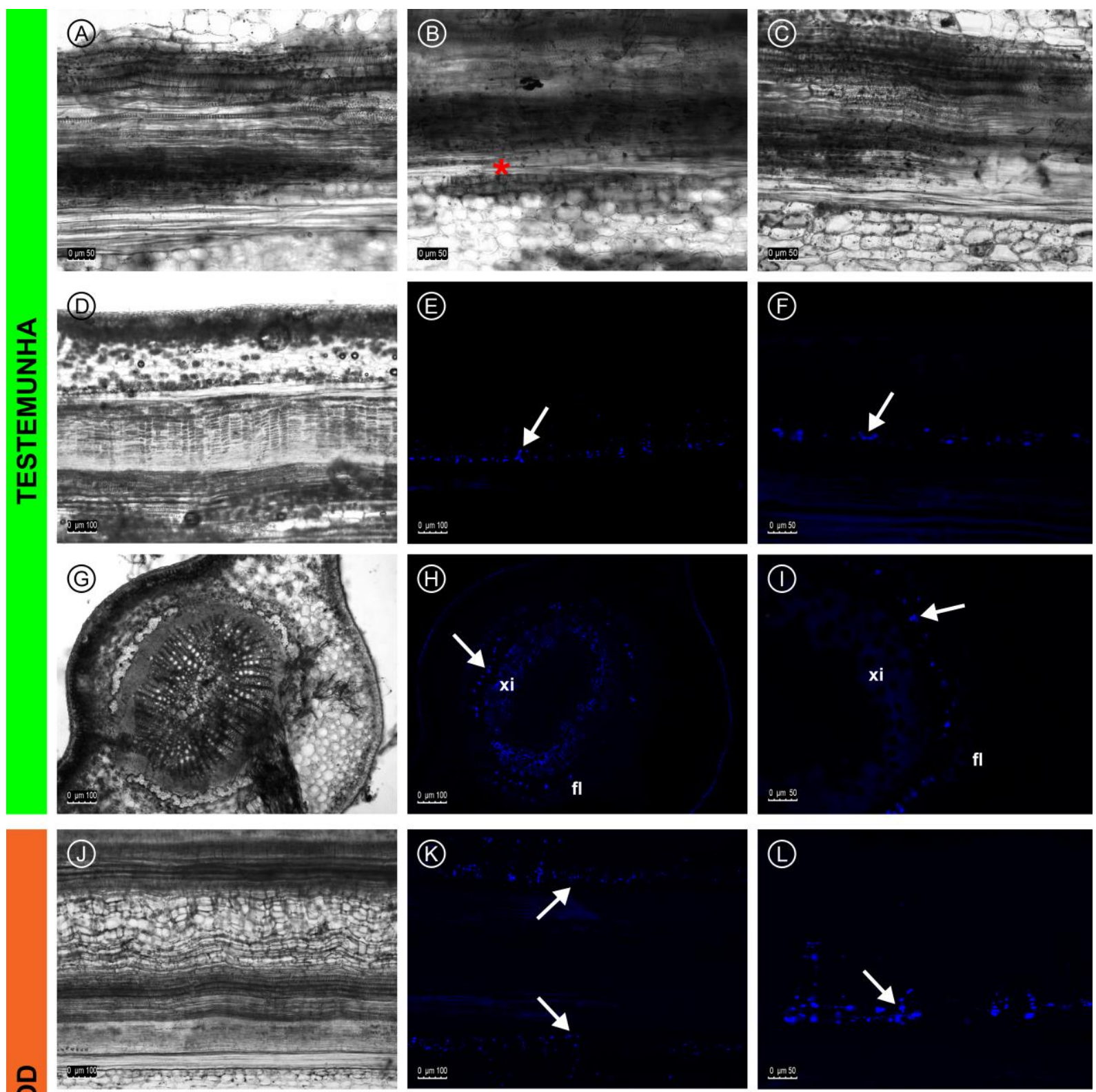

๗
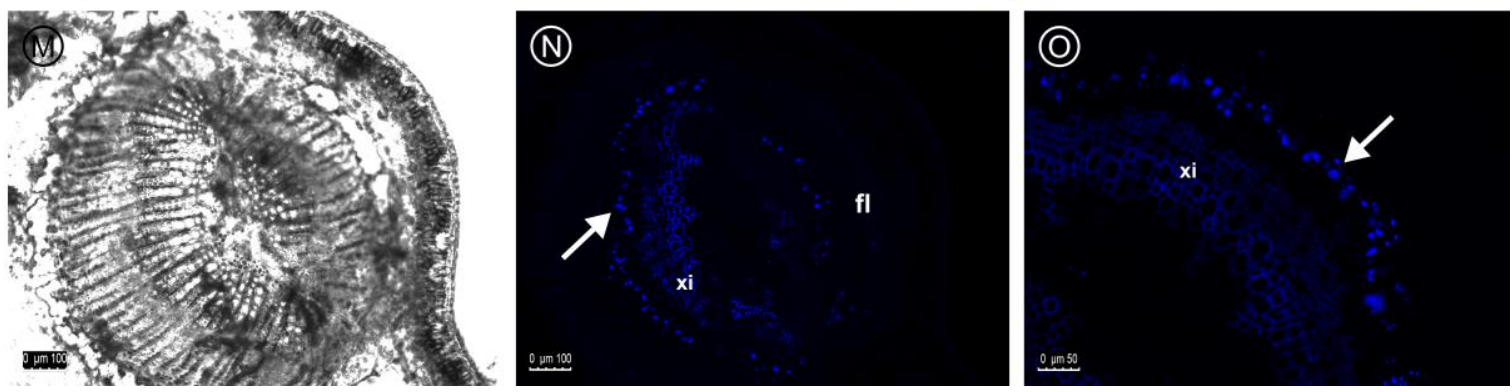

Figura 8. Deposição de calose em segmentos foliares de laranja 'Hamlin'. Seções longitudinais (A, B, C, D, E, F, J, K, L); seções transversais (G, H, I, M, N, O); microscopia de luz (A, B, C, D, G, $\mathrm{J}, \mathrm{M})$; microscopia de epifluorescência após o método de coloração com azul de anilina (E, F, H, I, K, L, N, O). Plantas não inoculadas com CLas (A, B, C). Plantas não transgênicas (T1), inoculadas com $C$ Las (D, E, F, G, H, I). Plantas transgênicas (evento TG4-2, gene csdl), inoculadas com $C$ Las $(\mathrm{J}, \mathrm{K}, \mathrm{L}, \mathrm{M}, \mathrm{N}, \mathrm{O}$ ). A deposição de calose (setas brancas) ocorreu em todas as plantas inoculadas, porém em maior evidência nas áreas de infecções do evento transgênico. fl: floema; xi: xilema; *(em vermelho), pontos de calose. 
Determinação da matéria seca das plantas e análise química das folhas

As plantas transgênicas e não transgênicas inoculadas com CLas foram utilizadas, destrutivamente, para a determinação da matéria seca da parte aérea e do sistema radicular, 18 m.a.i.. As plantas testemunhas (não transgênicas) de laranja 'Hamlin' não inoculadas (sadias) apresentaram maiores valores médios de matéria seca da parte aérea e também maiores valores médios de matéria seca do sistema radicular, em comparação com os demais tratamentos avaliados (Tabela 3).

Amostras de eventos transgênicos (TG3-14; TG3-16; TG3-19; TG4-2; TG4-3; TG46; TG4-9) expressando o gene csd1 e de eventos transgênicos (HS1; HS11; HS12; HS33; HS36; HS38; HS45; HS48) expressando o gene $d 4 e 1$ apresentaram valores superiores de matéria seca de parte aérea em relação às plantas não transgênicas (Testemunha 1). Amostra de evento transgênico (TG3-19) expressando o gene csd1, e de eventos transgênicos (HS33; HS36; HS48) expressando o gene $d 4 e 1$ apresentaram valores superiores de matéria seca do sistema radicular em relação às plantas não transgênicas (Testemunha 1) (Tabela 3). Os valores médios de matéria seca da parte aérea e de raiz não apresentaram diferenças significativas entre as plantas não transgênicas e as plantas com o vetor vazio (Vetor vazio 1 ).

Os eventos transgênicos que apresentaram maiores valores médios de matéria seca da parte aérea e de sistema radicular, tais como TG3-19; HS33; HS36; HS48, também demonstraram menores populações bacterianas em relação às médias das plantas não transgênicas, 18 m.a.i.. Esses eventos transgênicos apresentaram valores de 59,6\%, 110,4\%, $96,7 \%, 52,2 \%$, respectivamente, superiores de matéria seca de parte aérea, e de 102,2\%, $133,1 \%, 52,8 \%, 81,1 \%$, respectivamente, também superiores de matéria seca de sistema radicular, comparando-se com os valores médios das plantas não transgênicas (Tabela 4). Esses resultados sugerem que a presença de $C$ Las em maiores concentrações pode causar reduções significativas na biomassa de plantas cítricas jovens.

Por outro lado, alguns eventos transgênicos, tais como HS33; HS36; HS45; HS48, expressando o gene $d 4 e 1$ apresentaram títulos bacterianos elevados no tecido vegetal sem acarretar perdas significativas de massa da parte aérea e do sistema radicular, quando avaliadas 18 m.a.i. (Tabela 3). 
Tabela 3. Determinação dos valores médios de matéria seca † (expressa em gramas) da parte aérea e do sistema radicular de plantas transgênicas e não transgênicas de laranja 'Hamlin', 18 meses após a inoculação de $C$ Las, em Piracicaba, SP.

\begin{tabular}{|c|c|c|c|}
\hline & \multirow{2}{*}{ Tratamentos } & \multicolumn{2}{|c|}{ Matéria seca de plantas (gramas) } \\
\hline & & Parte aérea & Sistema radicular \\
\hline & Plantas sadias & $474,81^{*}$ & $260,64 *$ \\
\hline & Testemunha 1 & 218,34 & 95,02 \\
\hline & Vetor vazio 1 & 232,43 & 98,48 \\
\hline \multirow{10}{*}{ 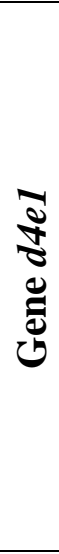 } & HS1 & $277,35^{*}$ & 101,52 \\
\hline & HS9 & 209,20 & 108,70 \\
\hline & HS11 & $325,29 *$ & 131,19 \\
\hline & HS12 & $313,71 *$ & 124,44 \\
\hline & HS13 & 252,40 & 115,28 \\
\hline & HS33 & $459,25^{*}$ & $221,49 *$ \\
\hline & HS36 & $429,55^{*}$ & $145,19 *$ \\
\hline & HS38 & $289,36^{*}$ & 125,25 \\
\hline & HS45 & $310,29 *$ & 114,10 \\
\hline & HS48 & $332,36^{*}$ & $172,03 *$ \\
\hline \multirow{14}{*}{ 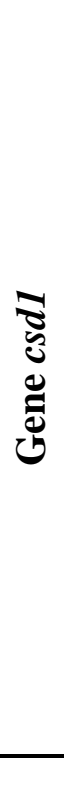 } & TG3-14 & $270,36^{*}$ & 114,31 \\
\hline & TG3-16 & $307,91^{*}$ & 96,90 \\
\hline & TG3-19 & $348,46^{*}$ & $192,14 *$ \\
\hline & TG3-26 & 188,58 & 82,97 \\
\hline & TG4-2 & $278,68 *$ & 138,03 \\
\hline & TG4-3 & $292,88^{*}$ & 114,28 \\
\hline & TG4-4 & 205,97 & 84,64 \\
\hline & TG4-6 & $342,49 *$ & 140,29 \\
\hline & TG4-9 & $266,21^{*}$ & 116,21 \\
\hline & TG4-11 & 181,54 & 68,56 \\
\hline & TG4-28 & 249,30 & 105,98 \\
\hline & TG4-33 & 249,72 & 106,44 \\
\hline & TG4-37 & 253,56 & 103,87 \\
\hline & C.V. (\%) & 8,47 & 12,74 \\
\hline
\end{tabular}

*Difere significativamente em relação à média das plantas não transgênicas (Testemunha 1 ), pelo teste de Dunnett $(P<0,05)$. C.V.: Coeficiente de variação. $†$ As plantas não foram podadas após a inoculação de $C$ Las. Plantas sadias: laranja 'Hamlin' (não transgênica) sem inoculação de $C$ Las.

Após a infecção por CLas, a distribuição e translocação de fotoassimilados nos tecidos vegetais tornam-se comprometidas, acarretando graves deficiências nutricionais em folhas das plantas cítricas afetadas por HLB. Diante disso, para compreender a interação entre a evolução da doença e a influência na disponibilidade de nutrientes, as concentrações foliares de 
macronutrientes de plantas transgênicas e não transgênicas foram analisados seis e 18 m.a.i. de CLas (Tabela 4).

As concentrações de macronutrientes analisadas em folhas de laranja 'Hamlin' não inoculadas com $C$ Las (plantas sadias) encontram-se adequados aos critérios estabelecidos pelo Grupo Paulista de Adubação e Calagem para Citros (GPACC, 1994), demonstrando que o manejo nutricional estabelecido no presente estudo foi adequado ao desenvolvimento de plantas cítricas (Tabela 4). Em relação às plantas inoculadas com CLas, de uma maneira geral, as concentrações de todos os macronutrientes em plantas não transgênicas (Testemunha 1) foram inferiores, comparando-se com aquelas dos eventos transgênicos, em ambos os períodos avaliados. As concentrações foliares dos nutrientes analisadas nas plantas não transgênicas foram semelhantes aos encontrados nas plantas com o vetor vazio (Vetor vazio 1) (Tabela 4).

Com a progressão da doença e o consequente surgimento dos sintomas de HLB, as concentrações foliares de nitrogênio $(\mathrm{N})$, fósforo $(\mathrm{P})$, potássio $(\mathrm{K})$ e cálcio $(\mathrm{Ca})$ sofreram reduções, entre os dois períodos analisados, na maioria das plantas avaliadas, conforme as análises obtidas 18 meses após a inoculação. Por sua vez, os teores de magnésio $(\mathrm{Mg})$ e enxofre (S) mantiveram-se relativamente constantes nos tecidos foliares entre as plantas dos tratamentos avaliados, entre os períodos analisados (Tabela 4). Entretanto, ao comparar as plantas transgênicas entre si, percebemos grandes variações nas concentrações dos macronutrientes. Esses resultados geram interpretações imprecisas na compreensão da relação dos títulos bacterianos obtidos e a influência na disponibilidade de nutrientes em plantas cítricas infectadas com CLas (Tabela 4). 
Tabela 4. Análise química foliar de macronutrientes $\left(\mathrm{g} \mathrm{kg}^{-1}\right)$ em plantas transgênicas e não transgênicas de laranja 'Hamlin', avaliadas seis e 18 meses após a inoculação de CLas, em Piracicaba, SP.

\begin{tabular}{|c|c|c|c|c|c|c|c|c|c|c|c|c|}
\hline \multirow{4}{*}{ Tratamentos } & \multicolumn{2}{|c|}{$\mathbf{N}$} & \multicolumn{2}{|c|}{$\mathbf{P}$} & \multicolumn{2}{|c|}{$\mathbf{K}$} & \multicolumn{2}{|c|}{$\mathbf{C a}$} & \multicolumn{2}{|c|}{ Mg } & \multicolumn{2}{|c|}{$\mathbf{S}$} \\
\hline & \multicolumn{12}{|c|}{ 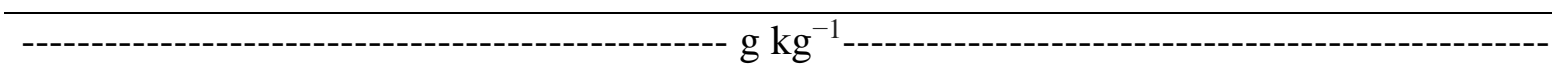 } \\
\hline & 6 & 18 & 6 & 18 & 6 & 18 & 6 & 18 & 6 & 18 & 6 & 18 \\
\hline & m.a.i. & m.a.i. & m.a.i. & m.a.i. & m.a.i. & m.a.i. & m.a.i. & m.a.i. & m.a.i. & m.a.i. & m.a.i. & m.a.i. \\
\hline Plantas sadias & 26,54 & 29,31 & 1,54 & 1,32 & 18,60 & 19,71 & 35,42 & 30,98 & 2,40 & 2,52 & 2,29 & 2,59 \\
\hline Testemunha 1 & 18,98 & 23,11 & 1,38 & 1,59 & 15,30 & 15,98 & 10,25 & 8,86 & 0,90 & 1,00 & 1,06 & 1,49 \\
\hline Vetor vazio 1 & 18,98 & 18,99 & 1,44 & 1,42 & 19,13 & 15,14 & 8,47 & 6,94 & 0,90 & 1,04 & 0,73 & 1,86 \\
\hline HS1 & 26,49 & 23,12 & 2,18 & 1,49 & 19,07 & 14,30 & 15,62 & 9,10 & 1,85 & 1,08 & 1,48 & 1,68 \\
\hline HS9 & 20,56 & 22,21 & 1,82 & 1,88 & 25,25 & 18,50 & 15,21 & 11,65 & 1,40 & 1,92 & 1,37 & 1,76 \\
\hline HS11 & 20,59 & 24,96 & 1,74 & 1,88 & 26,01 & 15,98 & 12,08 & 12,38 & 1,05 & 2,16 & 0,96 & 3,65 \\
\hline Ð HS12 & 25,04 & 22,24 & 1,98 & 1,41 & 26,72 & 16,82 & 14,72 & 10,23 & 1,45 & 0,92 & 2,43 & 1,74 \\
\hline HS13 & 29,81 & 21,37 & 1,85 & 2,03 & 26,78 & 17,66 & 14,06 & 11,26 & 1,25 & 1,80 & 1,22 & 2,05 \\
\hline HS33 & 28,03 & 23,93 & 1,61 & 1,92 & 27,54 & 16,82 & 14,15 & 12,16 & 1,05 & 1,76 & 1,29 & 2,59 \\
\hline HS36 & 25,96 & 19,76 & 1,66 & 1,74 & 18,36 & 15,98 & 11,97 & 9,75 & 1,35 & 1,68 & 1,23 & 1,76 \\
\hline HS38 & 29,03 & 21,76 & 2,11 & 1,73 & 20,60 & 15,14 & 15,32 & 8,97 & 1,50 & 1,60 & 1,49 & 2,01 \\
\hline HS45 & 27,32 & 19,84 & 1,64 & 1,33 & 16,07 & 13,46 & 10,65 & 9,23 & 1,10 & 1,04 & 0,99 & 1,71 \\
\hline HS48 & 30,46 & 22,09 & 1,79 & 1,63 & 21,42 & 17,66 & 12,40 & 11,19 & 1,35 & 1,32 & 1,29 & 2,25 \\
\hline TG3-14 & 29,61 & 20,63 & 2,37 & 1,67 & 26,01 & 15,98 & 12,23 & 9,32 & 1,20 & 1,40 & 1,63 & 1,86 \\
\hline TG3-16 & 24,16 & 18,32 & 1,74 & 1,65 & 22,19 & 14,30 & 12,97 & 9,28 & 1,25 & 1,20 & 1,49 & 1,76 \\
\hline TG3-19 & 25,33 & 23,37 & 1,72 & 1,69 & 16,07 & 15,14 & 9,29 & 11,15 & 1,25 & 1,64 & 1,55 & 1,95 \\
\hline TG3-26 & 28,61 & 20,09 & 2,34 & 1,55 & 22,95 & 17,66 & 18,56 & 14,50 & 1,30 & 1,52 & 1,49 & 2,53 \\
\hline TG4-2 & 28,86 & 21,09 & 2,19 & 1,92 & 22,95 & 15,98 & 14,86 & 9,44 & 1,30 & 1,32 & 1,47 & 1,98 \\
\hline TG4-3 & 27,27 & 22,03 & 1,68 & 2,01 & 18,36 & 17,66 & 13,32 & 11,56 & 1,60 & 2,16 & 1,51 & 2,64 \\
\hline TG4-4 & 23,11 & 28,65 & 1,66 & 1,83 & 16,83 & 17,66 & 10,30 & 11,58 & 1,20 & 2,12 & 1,30 & 2,01 \\
\hline $\bar{\Xi}$ TG4-6 & 28,71 & 26,52 & 1,63 & 1,68 & 19,13 & 15,98 & 15,16 & 8,48 & 1,40 & 1,24 & 1,49 & 1,82 \\
\hline TG4-9 & 25,52 & 22,04 & 1,63 & 1,42 & 19,13 & 14,30 & 7,69 & 10,65 & 0,80 & 1,00 & 0,89 & 2,07 \\
\hline TG4-11 & 26,10 & 25,52 & 1,79 & 2,00 & 25,25 & 15,14 & 13,85 & 9,82 & 1,15 & 1,60 & 1,55 & 1,71 \\
\hline TG4-28 & 35,38 & 29,14 & 2,20 & 1,68 & 26,01 & 15,14 & 16,87 & 9,03 & 1,05 & 1,28 & 1,42 & 2,10 \\
\hline TG4-33 & 28,58 & 19,91 & 1,96 & 1,63 & 26,78 & 12,62 & 12,93 & 11,07 & 1,40 & 1,40 & 1,59 & 2,10 \\
\hline TG4-37 & 29,15 & 25,83 & 2,27 & 1,65 & 22,95 & 14,30 & 16,41 & 10,38 & 1,40 & 1,40 & 2,47 & 1,82 \\
\hline
\end{tabular}

Nota: Faixas para interpretação dos resultados de macronutrientes $\left(\mathrm{g} \mathrm{kg}^{-1}\right)$ em folhas de citros (GPACC, 1994). N: Baixo <23, Adequado 23-27, Excessivo >30. P: Baixo <1,2, Adequado 1,2-1,6, Excessivo >2. $\mathrm{K}$ : Baixo <10, Adequado 10-15, Excessivo >20. Ca: Baixo <35, Adequado 35-45, Excessivo >45. Mg: Baixo <2,5, Adequado 2,5-4, Excessivo $>5$. S: Baixo $<2$, Adequado 2-3, Excessivo $>5$.

Os resultados da análise química foliar dos macronutrientes foram interpretados de acordo com os critérios estabelecidos pelo Grupo Paulista de Adubação e Calagem para Citros (1994). Ressalta-se que esses critérios foram estabelecidos pelo GPACC para plantas adultas, sendo que não há na literatura interpretações dos resultados de concentrações foliares de macronutrientes em folhas de citros para mudas ou plantas jovens. 
Desta forma, as plantas não transgênicas, em ambos os períodos analisados, demonstraram concentrações foliares de $\mathrm{N}, \mathrm{Ca}, \mathrm{Mg}$ e $\mathrm{S}$ abaixo da faixa de suficiência nutricional recomendada, e apenas os nutrientes $\mathrm{P}$ e $\mathrm{K}$ estavam em concentrações adequadas. Em relação aos eventos transgênicos, os teores foliares de $\mathrm{Ca}, \mathrm{Mg}$ e $\mathrm{S}$ foram baixos para a maioria das plantas avaliadas e os teores nutricionais de $\mathrm{P}$ e $\mathrm{K}$ estavam excessivos, em ambos os períodos analisados. As concentrações foliares de $\mathrm{N}$, por sua vez, apresentaram teores adequados, na primeira avaliação, e baixos, na segunda avaliação, de acordo com os critérios do GPACC (1994). As concentrações foliares, principalmente, de N, K e Ca presentes nas plantas transgênicas e não transgênicas infectadas por HLB sofreram reduções drásticas, comparando-se entre as duas análises. Esses resultados corroboram as interpretações de Malavolta et al. (2005) que afirmavam que os teores de N, K, Ca, Mg e S sofrem reduções nas concentrações foliares após a infecção por $C$ Las, sendo que apenas os teores nutricionais de $\mathrm{P}$ aumentam com a evolução dos sintomas de HLB em plantas cítricas.

\section{Distribuição espacial de nutrientes em folhas de laranjeiras doces}

Para compreender as possíveis influências do HLB na distribuição espacial de macro e micronutrientes presentes no tecido foliar de plantas cítricas, análises semiquantitativas por espectroscopia de fluorescência de raios X com feixe micrométrico ( $\mu$-XRF) foram realizadas em complemento às análises químicas foliares, em folhas de laranjas 'Hamlin' sadias (não inoculadas) e em folhas de plantas não transgênicas infectadas por CLas. As intensidades dos elementos avaliados ( $\mathrm{Zn}, \mathrm{Fe}, \mathrm{Mn}, \mathrm{Cu}, \mathrm{Ca}, \mathrm{K}, \mathrm{S}$ e P) nos tecidos foliares de plantas de laranja 'Hamlin' infectadas pela bactéria foram comparadas com aquelas obtidas em folhas de plantas sadias. De maneira geral, os elementos apresentaram maiores intensidades nas nervuras centrais das folhas amostradas. Para os macronutrientes, os resultados indicaram uma distribuição espacial de P e S muito similares entre as plantas sem e com HLB (Figura 9A e Figura 9C). Ambos os elementos apresentaram estar distribuídos homogeneamente ao longo das folhas, e com uma variação muito próxima das intensidades entre as replicatas de cada tratamento.

Embora disponíveis em maiores intensidades dentre os macronutrientes analisados, os níveis de $\mathrm{K}$ e $\mathrm{Ca}$ encontrados nas folhas das plantas com HLB apresentaram reduções de intensidades consistentes, comparando-se com as amostras de folhas sadias. As intensidades dos elementos $\mathrm{K}$ e Ca encontradas em folhas sem HLB variaram de 0,1214 a 0,2000, e 0,1005 a 0,1458 para a replicata 1 (L1, Figura 9A), respectivamente, e de 0,0846 a 0,1480, e 0,0639 a 0,1316 para a replicata 2 (L2, Figura 9B), respectivamente. Neste caso, uma queda acentuada 
na intensidade do elemento $\mathrm{K}$ foi observada das extremidades da folha para a região central (Figura 9A). As folhas de plantas inoculadas tiveram intensidades destes macronutrientes variando de 0,0271 a 0,1915, e 0,0106 a 0,00925 para a replicata 1 (L1, Figura 9C), respectivamente, e de 0,0159 a 0,2199, e 0,0059 a 0,0855 para a replicata 2 (L2, Figura 9D), respectivamente. Os resultados de espectroscopia de fluorescência por raios X obtidos para os macronutrientes corroboram os resultados referentes às análises químicas foliares, as quais também apresentaram teores superiores de $\mathrm{K}$ e $\mathrm{Ca}$ em relação aos teores de $\mathrm{P}$ e $\mathrm{S}$. Esse comportamento também é observado comparando-se as plantas sadias com as infectadas, sendo que estas apresentaram concentrações inferiores em todos os macronutrientes analisados (Figura 9J).

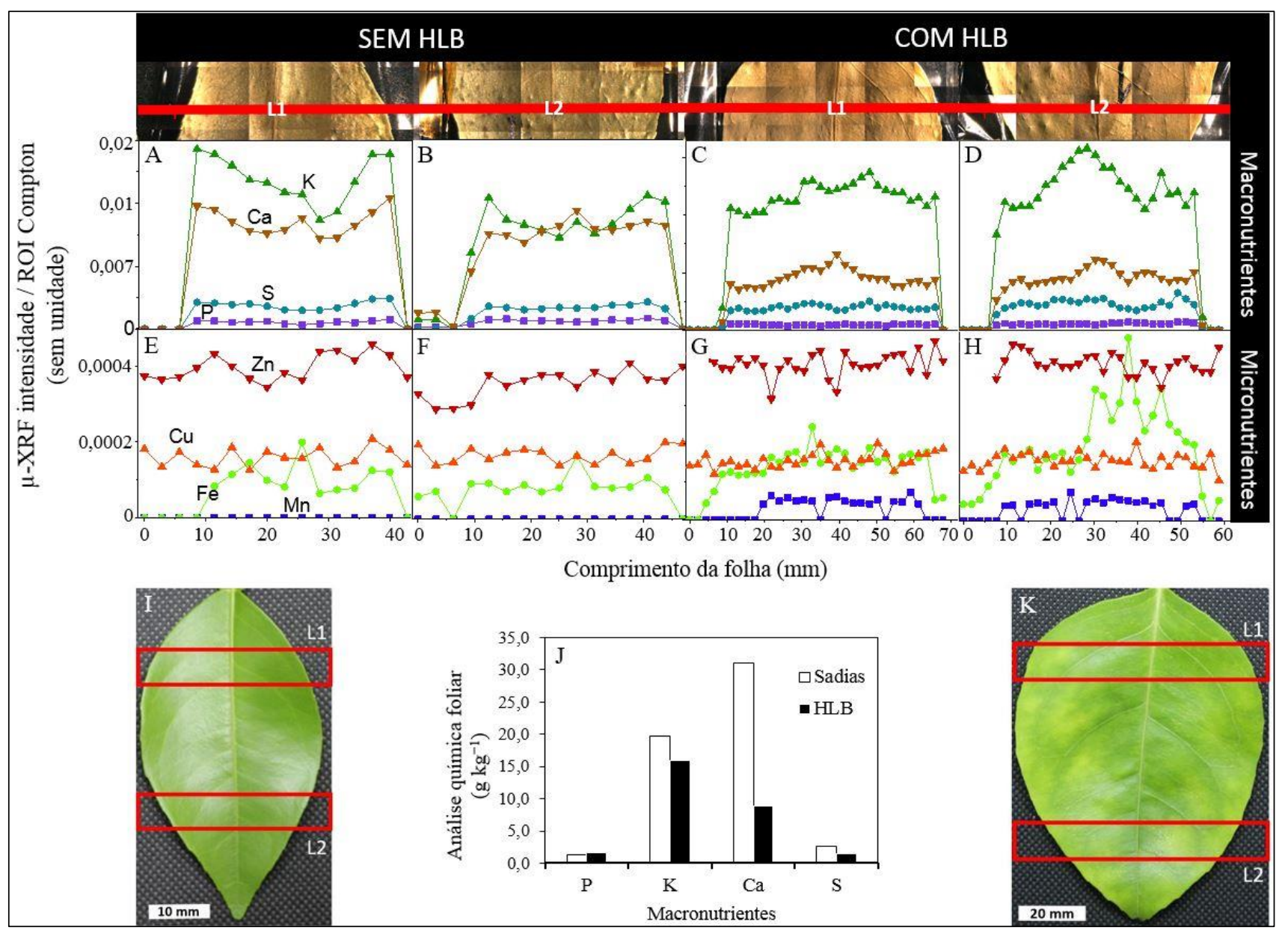

Figura 9. Análise in vivo da distribuição espacial de macronutrientes (A, B, C, D) e micronutrientes (E, $F, G, H)$ através da espectroscopia de fluorescência de raios $X(\mu-X R F)$ em folhas de laranjeiras doces sem (I) e com HLB (K). Análise química foliar de macronutrientes de laranjeiras doces (J). Todas as intensidades elementares de XRF foram normalizadas pelo espalhamento ROI Compton (COMPTON, 1923). Replicata 1 (L1), replicata 2 (L2).

As intensidades de micronutrientes presentes nas folhas avaliadas não sofreram grandes variações entre as plantas sadias em comparação com as plantas inoculadas por CLas. 
As intensidades de $\mathrm{Zn}$ mantiveram-se similares em ambas as replicatas analisadas de cada amostra, variando de 0,00034 a 0,00045 na replicata 1 (L1, Figura 9E), e 0,00029 a 0,00041 na replicata 2 (L2, Figura 9F), em folhas de plantas sem HLB, e de 0,00031 a 0,00045, na replicata 1 (L1, Figura 8G), e 0,00035 a 0,00047 na replicata 2 (L2, Figura 9H), em folhas das plantas com HLB. Os demais micronutrientes foliares analisados mantiveram intensidades uniformes e distribuições similares entre os tecidos das plantas amostradas. O manganês não foi detectado nas condições instrumentais empregadas em nenhuma das folhas de plantas sadias amostradas (Figuras 9E e 9F).

\subsection{Reação de plantas transgênicas de laranja doce à infecção por Xcc}

Inoculação por aspersão

O desenvolvimento dos primeiros sintomas visuais de cancro cítrico nas plantas avaliadas ocorreu entre cinco e sete dias após a inoculação, nos três experimentos realizados, com o aparecimento de pequenas lesões levemente salientes, puntiformes, progredindo para pústulas de coloração marrom-clara. Cinco avaliações para quantificar a incidência e severidade da doença foram realizadas, semanalmente, até $35 \mathrm{DAI}$, de acordo com a escala diagramática elaborada por Belasque et al. (2005). O experimento foi repetido três vezes. Os resultados destes experimentos indicaram variações na suscetibilidade dos diferentes genótipos e foram demonstrados independentemente. Nenhuma das plantas transgênicas apresentou deformações nas folhas ou anormalidades no crescimento vegetativo ou qualquer outra alteração no fenótipo.

No primeiro experimento, inoculado no dia 05/04/2017, as plantas expressando o gene $d 4 e l$ ou o gene $c s d l$ apresentaram reduções na incidência e severidade dos sintomas da doença em comparação com as plantas não transgênicas (Testemunha - T1). A incidência de cancro cítrico, avaliada 35 DAI, variou de 35,76\% a 100\% entre os genótipos estudados (Figura 10). A quantificação da incidência de cancro cítrico revelou que cinco eventos transgênicos foram significativamente menos suscetíveis ao cancro cítrico quando comparados com as plantas não transgênicas. Entretanto, a quantificação da severidade da doença demonstrou diferença significativa apenas nos eventos transgênicos TG4-4 e TG4-9, apresentando reduções de $64,27 \%$ e 67,93\%, respectivamente, em relação às plantas não transgênicas, no primeiro experimento (Figura 11). 


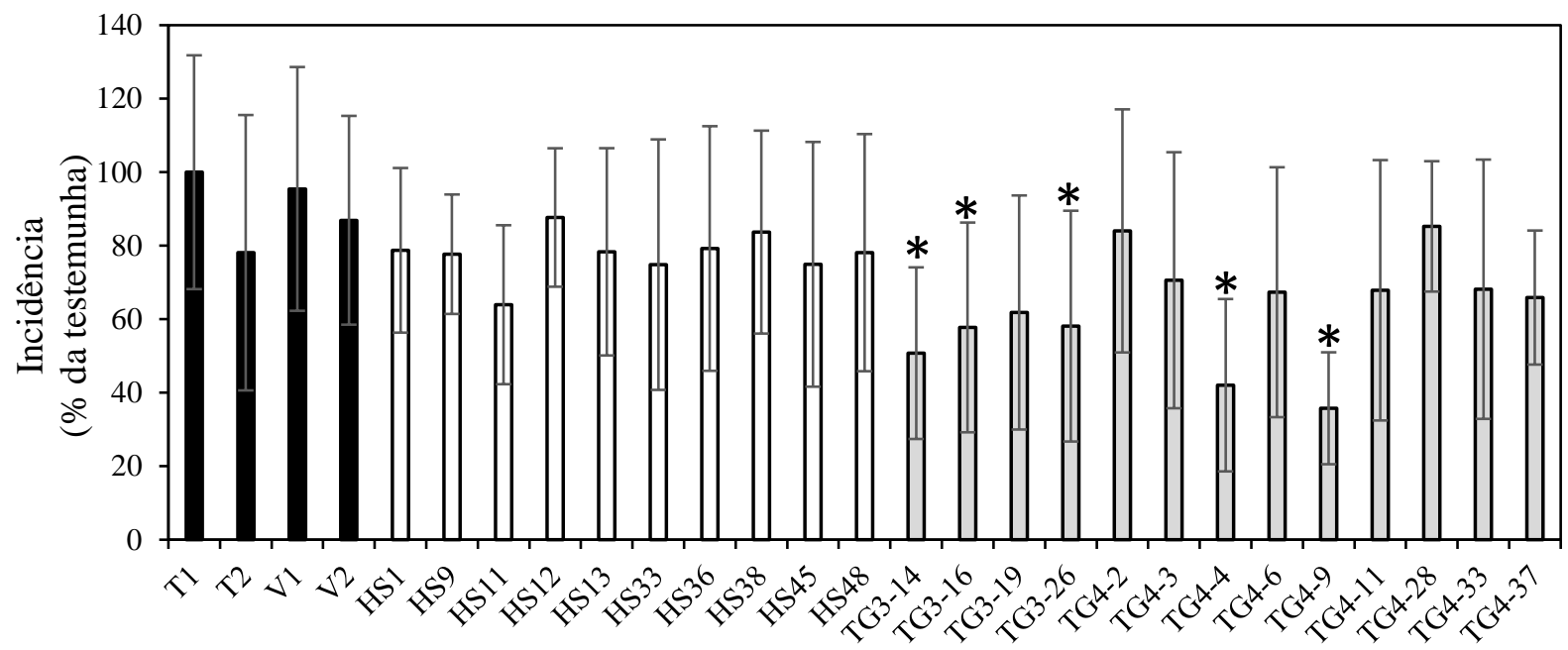

Plantas transgênicas

Figura 10. Incidência de cancro cítrico nas plantas transgênicas medida pela porcentagem de folhas com sintomas, comparada às plantas não transgênicas, $35 \mathrm{DAI}$, no primeiro experimento. Os valores apresentados são percentuais relativos à T1 e (*) indica diferença significativa pelo teste de Dunnett $(P<0,05)$. Cada coluna representa a média de 12 plantas. As barras indicam desvio padrão das médias.

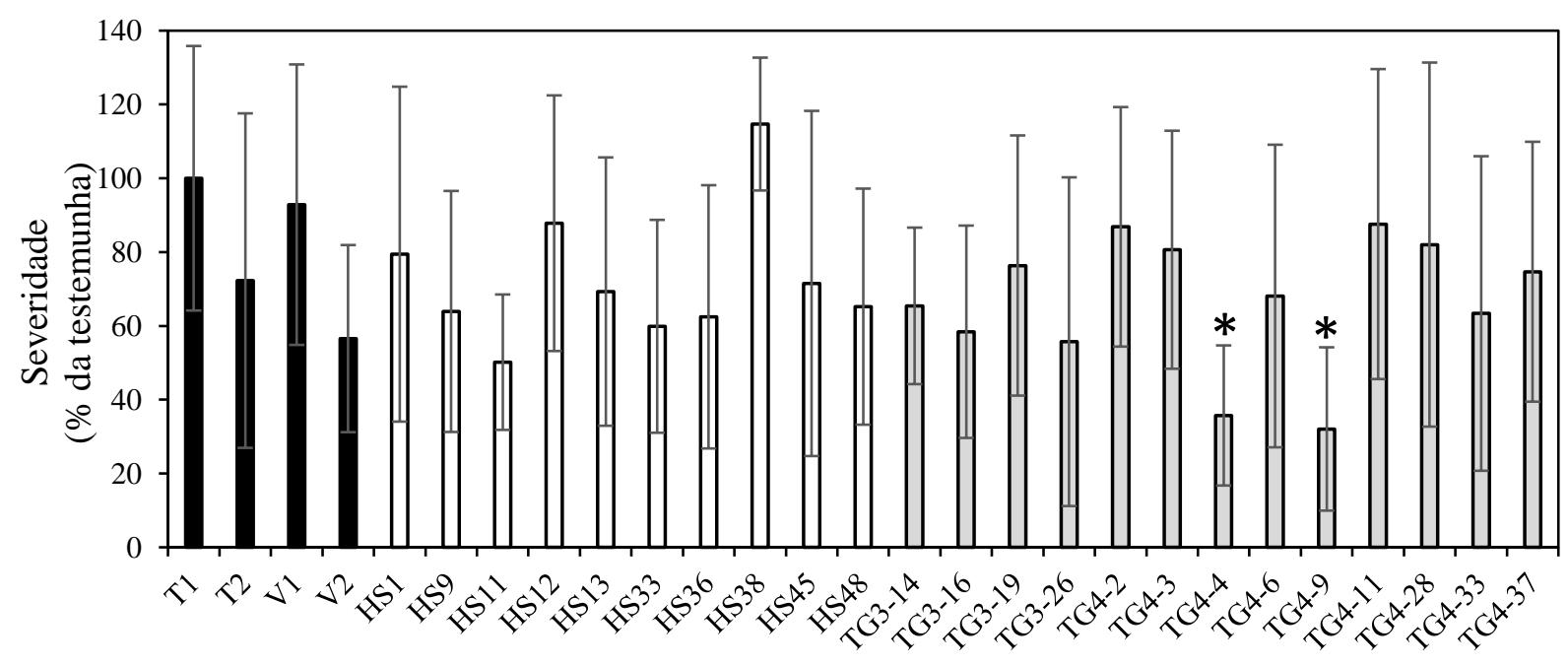

Plantas transgênicas

Figura 11. Severidade de cancro cítrico nas plantas transgênicas medida pela porcentagem de área foliar com lesão, comparada às plantas não transgênicas, $35 \mathrm{DAI}$, no primeiro experimento. Os valores apresentados são percentuais relativos à $\mathrm{T} 1 \mathrm{e}(*)$ indica diferença significativa pelo teste de Dunnett $(P<0,05)$. Cada coluna representa a média de 12 plantas. As barras indicam desvio padrão das médias.

A quantificação da incidência e da severidade da doença no segundo experimento, inoculado no dia 01/11/2017, mostrou que alguns eventos transgênicos expressando o gene $d 4 e 1$ ou o gene $c s d l$ aumentaram a resistência das plantas à infecção por Xcc. Nove eventos transgênicos analisados mostraram reduções significativas na incidência ao cancro cítrico, 35 
DAI (Figura 12). Os eventos transgênicos (HS9; HS11; HS33) expressando o gene $d 4 e 1$ e os eventos transgênicos (TG4-6; TG4-9) expressando o gene csdl apresentaram diferenças significativas, reduzindo em 72,03\%, 67,33\%, 72,70\%, 77,39\%, 85,39\%, respectivamente, a severidade da doença, em comparação com a média das plantas não transgênicas (Figura 13).

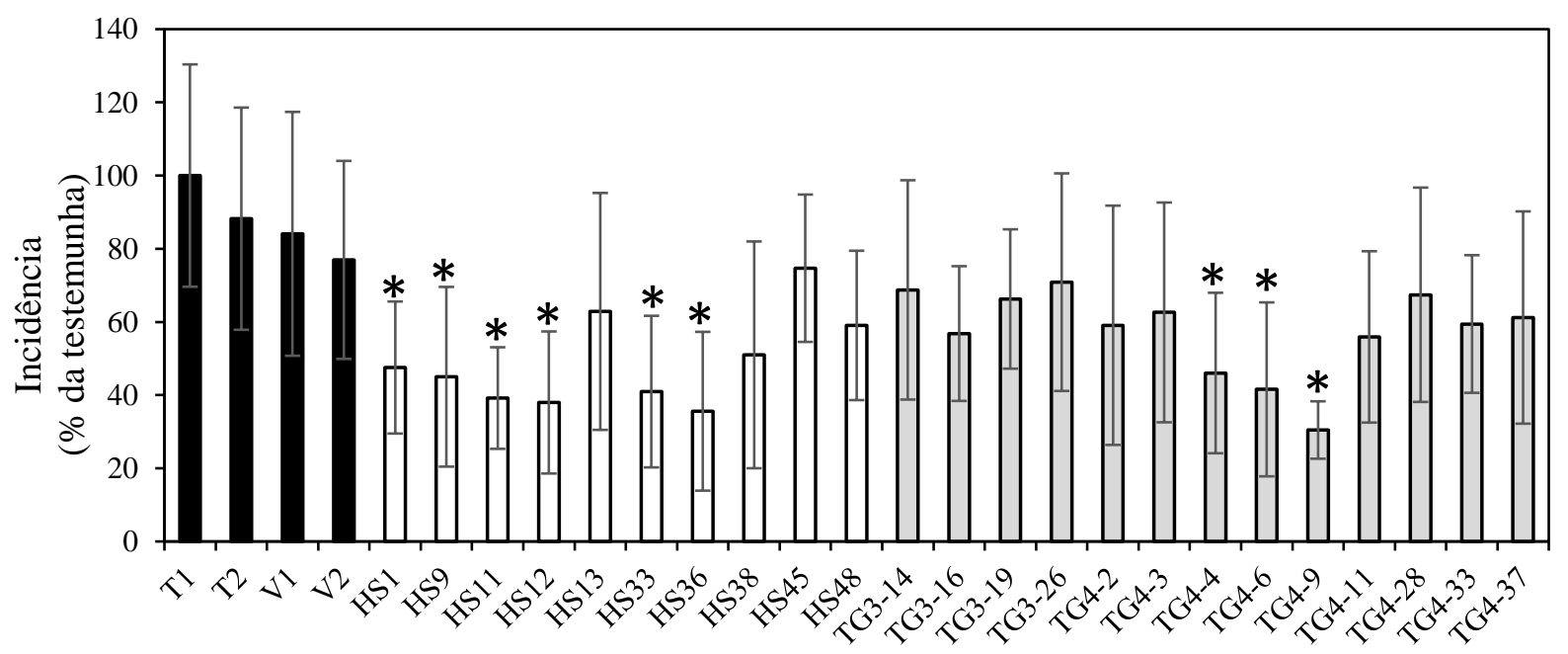

Plantas transgênicas

Figura 12. Incidência de cancro cítrico nas plantas transgênicas medida pela porcentagem de folhas com sintomas, comparada às plantas não transgênicas, 35 DAI, no segundo experimento. Os valores apresentados são percentuais relativos à T1 e (*) indica diferença significativa pelo teste de Dunnett $(P<0,05)$. Cada coluna representa a média de 12 plantas. As barras indicam desvio padrão das médias.

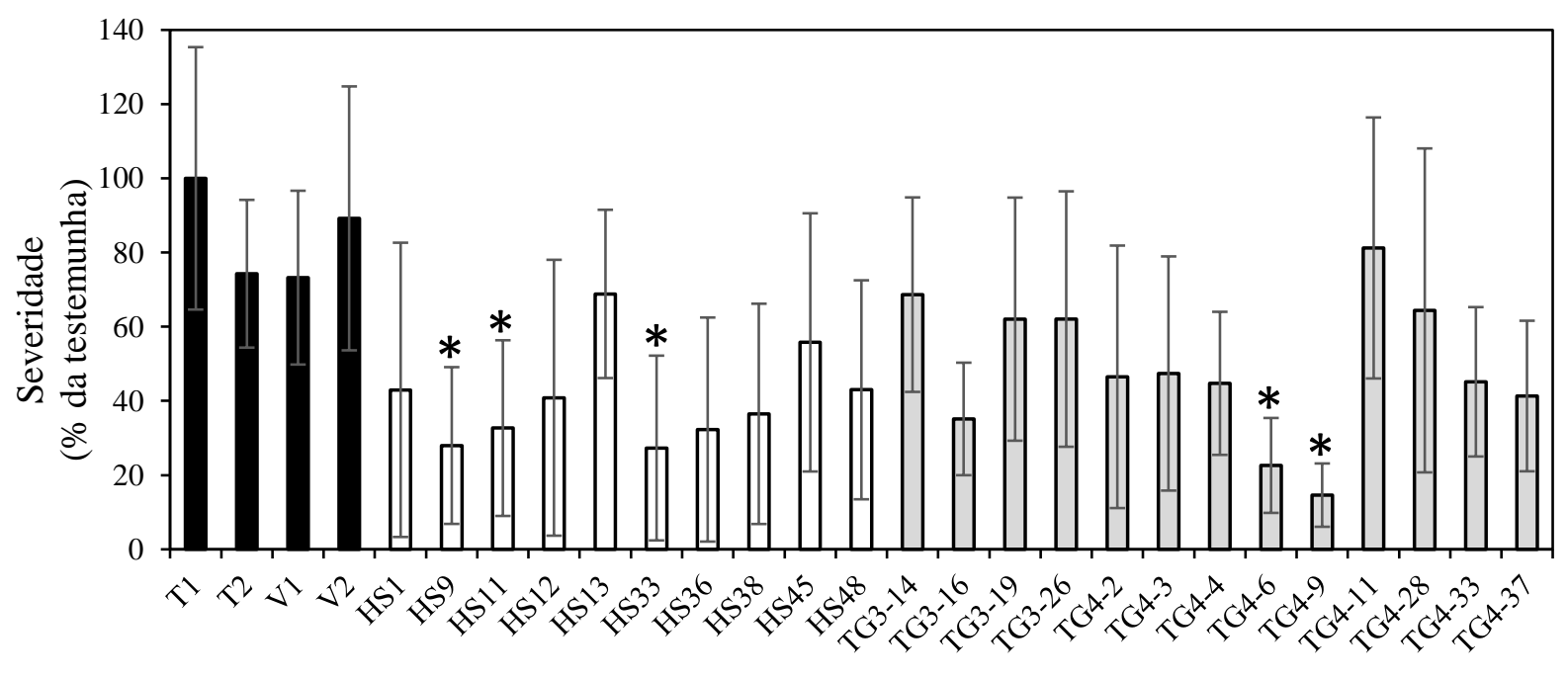

Plantas transgênicas

Figura 13. Severidade de cancro cítrico nas plantas transgênicas medida pela porcentagem de área foliar com lesão, comparada às plantas não transgênicas, $35 \mathrm{DAI}$, no segundo experimento. Os valores apresentados são percentuais relativos à T1 e (*) indica diferença significativa pelo teste de Dunnett $(P<0,05)$. Cada coluna representa a média de 12 plantas. As barras indicam desvio padrão das médias. 
No terceiro experimento, inoculado no dia 02/02/2018, a quantificação da incidência de cancro cítrico, avaliada 35 DAI, mostrou que alguns eventos transgênicos expressando o gene $d 4 e 1$ (HS11; HS12; HS38) ou o gene csd1 (TG3-14; TG3-16; TG3-19; TG4-2; TG4-4; TG4-9; TG4-11) foram significativamente menos suscetíveis à doença, quando comparados com as plantas não transgênicas (Figura 14). A severidade da doença nos eventos (HS11; HS38; TG3-14; TG3-16; TG4-2; TG4-4; TG4-9; TG4-11) foi reduzida significativamente, variando de 62,80\% a 77,84\%, em relação às plantas testemunhas (Figura 15).

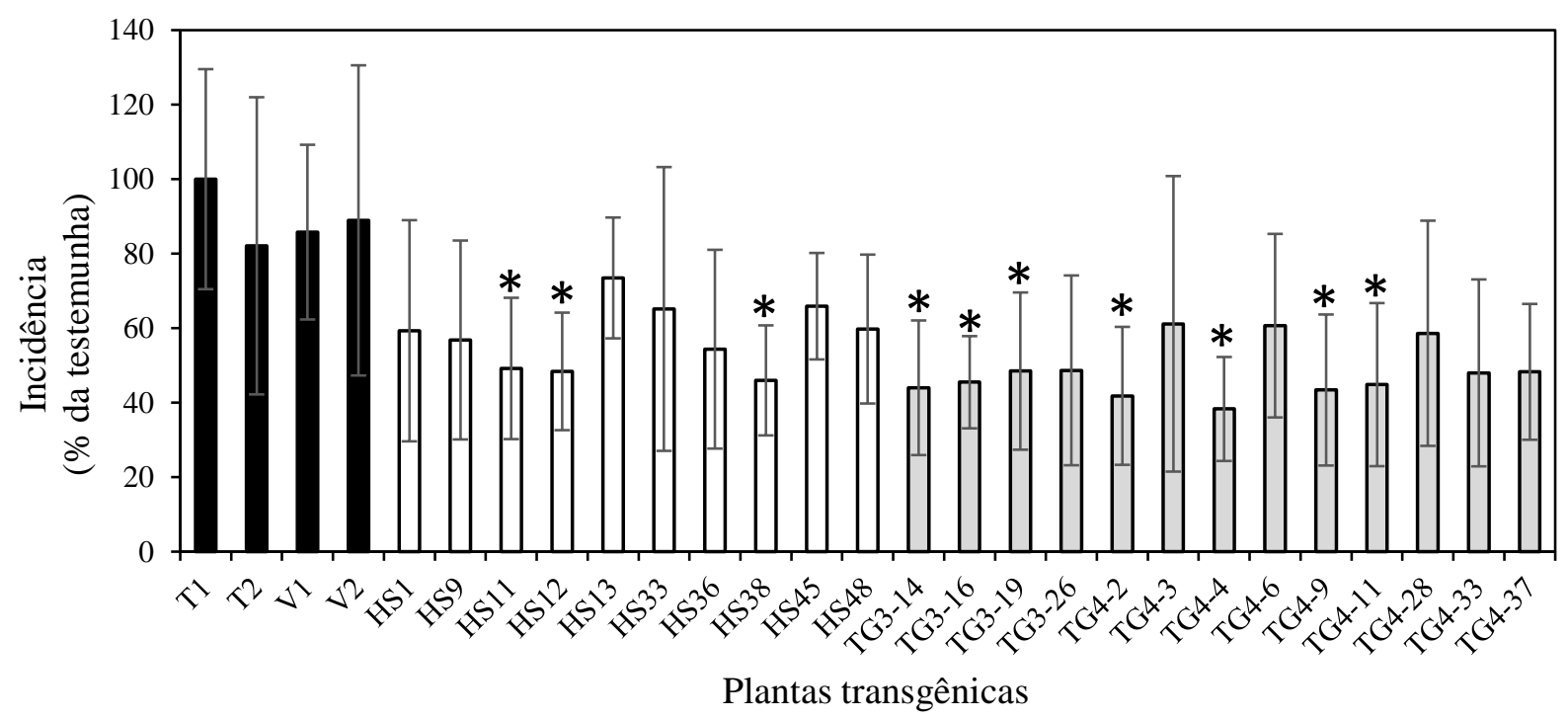

Figura 14. Incidência de cancro cítrico nas plantas transgênicas medida pela porcentagem de folhas com sintomas, comparada às plantas não transgênicas, $35 \mathrm{DAI}$, no terceiro experimento. Os valores apresentados são percentuais relativos à T1 e (*) indica diferença significativa pelo teste de Dunnett $(P<0,05)$. Cada coluna representa a média de 12 plantas. As barras indicam desvio padrão das médias. 


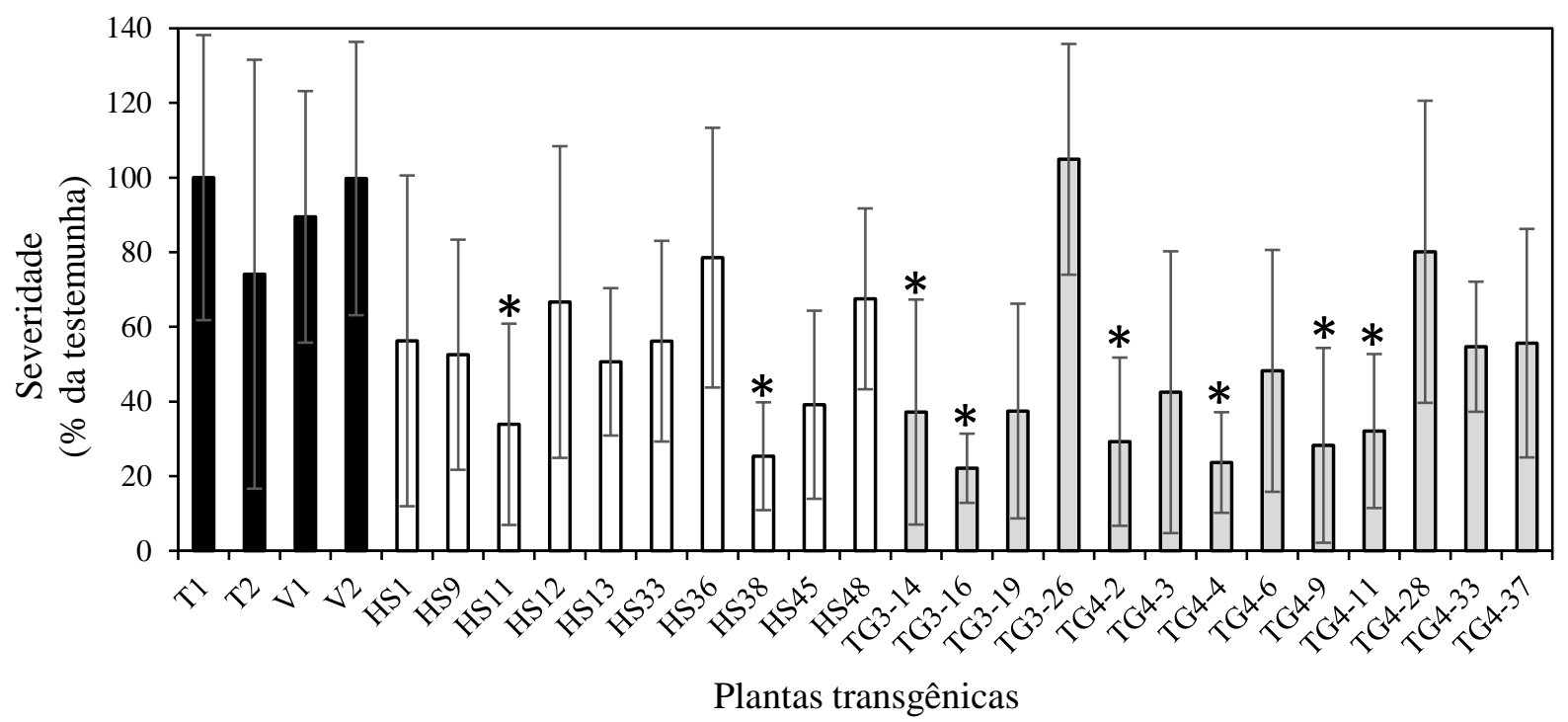

Figura 15. Severidade de cancro cítrico nas plantas transgênicas medida pela porcentagem de área foliar com lesão, comparada às plantas não transgênicas, 35 DAI, no terceiro experimento. Os valores apresentados são percentuais relativos à T1 e (*) indica diferença significativa pelo teste de Dunnett $(P<0,05)$. As barras indicam desvio padrão das médias.

O evento transgênico TG4-9 expressando o gene $c s d l$ foi o genótipo que apresentou maior resistência média à infecção por $X c c$, entre todas as plantas cítricas avaliadas, apresentando menor incidência e severidade de cancro cítrico, 35 DAI, nos três experimentos avaliados. O evento transgênico TG4-28, expressando o gene $c s d l$, por sua vez, foi o genótipo mais suscetível ao cancro cítrico em todas as avaliações realizadas, de acordo com a quantificação de incidência e severidade da doença (Figura 16). 

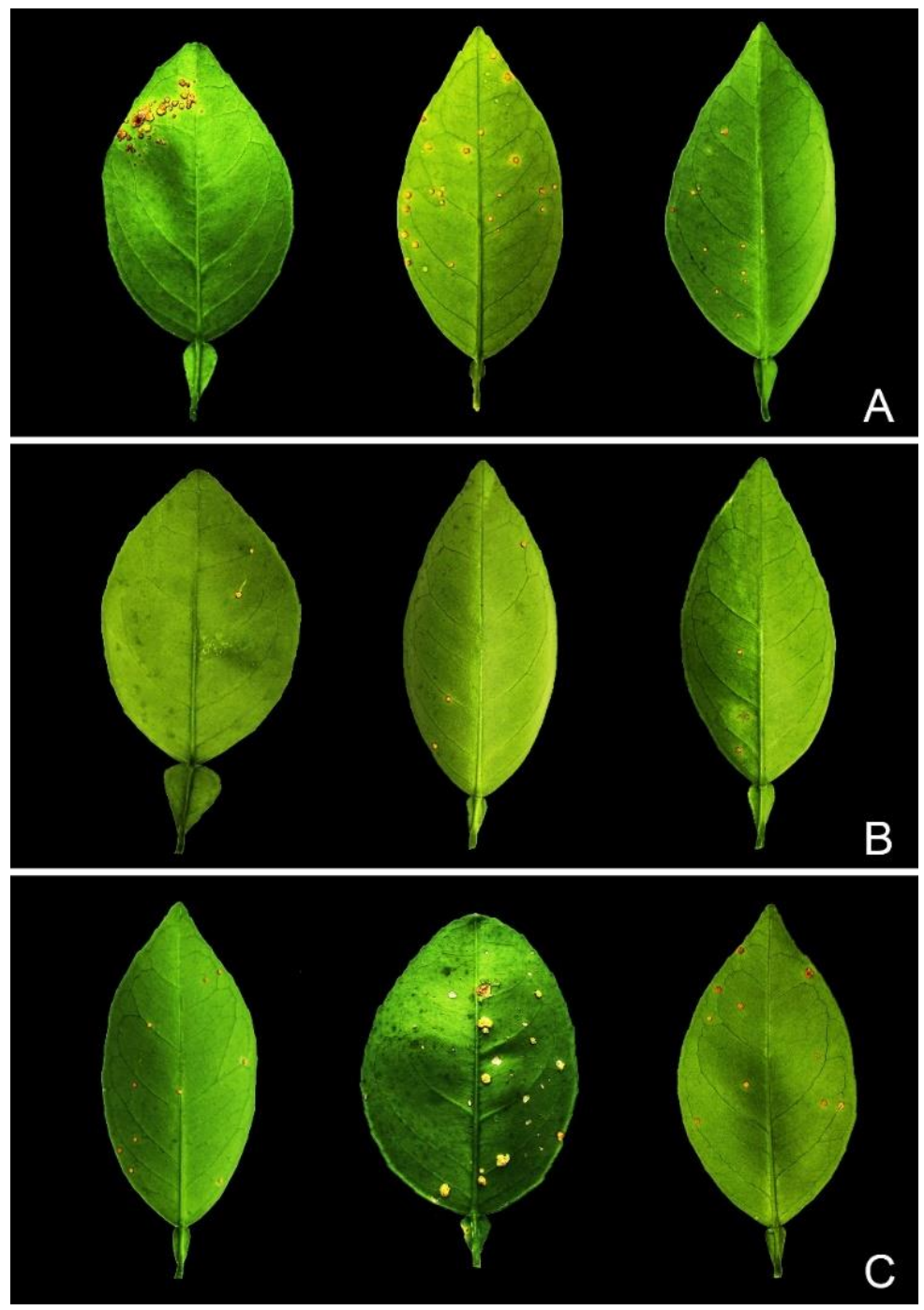

Figura 16. Severidade de cancro cítrico em folhas de laranja 'Hamlin', 35 DAI. (A) Folhas do evento transgênico (TG4-28) mais suscetível à infecção por Xcc. (B) Folhas do evento transgênico (TG4-9) menos suscetível. (C) Folhas de plantas não transgênicas. Ilustração representativa dos resultados médios obtidos dos três experimentos independentes.

A evolução da incidência e severidade de cancro cítrico nas folhas de plantas transgênicas e não transgênicas analisadas, durante as cinco avaliações, foram quantificadas através da área abaixo da curva de progresso da doença (AACPD), em três experimentos independentes. Os resultados representam o aumento médio diário de incidência e severidade de cancro cítrico da área abaixo da curva de progresso da doença padronizada pelo tempo de avaliação (Tabela 5). 
Tabela 5. Aumento médio $†$ diário de incidência e severidade de cancro cítrico da área abaixo da curva de progresso da doença (AACPD) em função do tempo, em folhas de laranja 'Hamlin' transgênicas e não transgênicas, obtido em três experimentos independentes, em Piracicaba, SP.

\begin{tabular}{|c|c|c|c|c|c|c|c|}
\hline & \multirow[t]{2}{*}{ Tratamentos } & \multicolumn{3}{|c|}{$\begin{array}{l}\text { Aumento médio diário de } \\
\text { incidência da AACPD }\end{array}$} & \multicolumn{3}{|c|}{$\begin{array}{l}\text { Aumento médio diário de } \\
\text { severidade da AACPD }\end{array}$} \\
\hline & & $1^{\circ} \mathrm{exp}$. & $2^{\circ}$ exp. & $3^{\circ}$ exp. & $1^{\circ}$ exp. & $2^{\circ}$ exp. & $3^{\circ} \mathrm{exp}$. \\
\hline & Testemunha 1 & 26,26 & 30,81 & 29,81 & 0,082 & 0,122 & 0,121 \\
\hline & Testemunha 2 & 23,57 & 24,07 & 21,63 & 0,068 & 0,082 & 0,065 \\
\hline & Vetor vazio 1 & 24,64 & 19,01 & 20,22 & 0,072 & 0,050 & 0,068 \\
\hline & Vetor vazio 2 & 23,98 & 18,87 & 27,73 & 0,066 & 0,049 & 0,114 \\
\hline \multirow{10}{*}{ 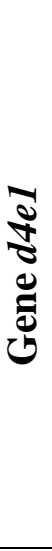 } & HS1 & 23,93 & $12,69^{*}$ & $13,76^{*}$ & 0,085 & $0,046^{*}$ & 0,042 \\
\hline & HS9 & 23,39 & $10,55^{*}$ & $11,66^{*}$ & 0,063 & $0,029 *$ & 0,038 \\
\hline & HS11 & 16,69 & $9,86^{*}$ & 13,99 & 0,052 & $0,033^{*}$ & 0,044 \\
\hline & HS12 & 29,35 & $14,24^{*}$ & $13,05^{*}$ & 0,093 & 0,050 & 0,050 \\
\hline & HS 13 & 24,57 & $15,30^{*}$ & $12,15^{*}$ & 0,069 & 0,073 & 0,036 \\
\hline & HS33 & 24,66 & $11,61^{*}$ & 19,22 & 0,071 & $0,034^{*}$ & 0,084 \\
\hline & HS36 & 22,16 & $11,09^{*}$ & 18,15 & 0,066 & $0,035^{*}$ & 0,054 \\
\hline & HS38 & 33,94 & $17,31 *$ & 15,83 & 0,137 & $0,046^{*}$ & 0,052 \\
\hline & HS45 & 21,17 & 19,43 & 21,49 & 0,064 & 0,061 & 0,092 \\
\hline & HS48 & 20,05 & $17,31^{*}$ & 15,54 & 0,060 & 0,047 & 0,057 \\
\hline \multirow{14}{*}{ 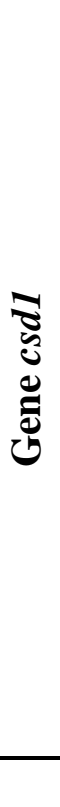 } & TG3-14 & 19,67 & 22,80 & $12,73 *$ & 0,090 & 0,077 & 0,041 \\
\hline & TG3-16 & 22,22 & $17,42^{*}$ & $12,39 *$ & 0,073 & 0,060 & $0,027 *$ \\
\hline & TG3-19 & 17,80 & $14,76^{*}$ & $13,57^{*}$ & 0,068 & 0,054 & 0,041 \\
\hline & TG3-26 & 18,03 & 20,78 & 15,15 & 0,050 & 0,084 & 0,092 \\
\hline & TG4-2 & 29,98 & 22,64 & $11,88^{*}$ & 0,109 & 0,090 & 0,034 \\
\hline & TG4-3 & 24,91 & $17,51^{*}$ & 16,43 & 0,099 & 0,055 & 0,052 \\
\hline & TG4-4 & $13,34^{*}$ & $13,16^{*}$ & $8,06^{*}$ & $0,033^{*}$ & $0,045^{*}$ & $0,021 *$ \\
\hline & TG4-6 & 22,76 & $13,08^{*}$ & $13,53^{*}$ & 0,064 & $0,036^{*}$ & 0,037 \\
\hline & TG4-9 & $13,87^{*}$ & $10,60^{*}$ & $9,65^{*}$ & $0,041^{*}$ & $0,032 *$ & $0,025^{*}$ \\
\hline & TG4-11 & 26,36 & 20,52 & $11,43^{*}$ & 0,113 & 0,081 & 0,032 \\
\hline & TG4-28 & 35,10 & 24,05 & 18,63 & 0,109 & 0,121 & 0,087 \\
\hline & TG4-33 & 23,03 & $17,02 *$ & 14,22 & 0,067 & 0,048 & 0,032 \\
\hline & TG4-37 & 24,14 & $15,66^{*}$ & 14,65 & 0,088 & $0,041 *$ & 0,057 \\
\hline & C.V. (\%) & 36,04 & 46,78 & 44,15 & 46,47 & 51,25 & 41,99 \\
\hline
\end{tabular}

*Difere significativamente em relação à média das plantas não transgênicas (Testemunha 1), em cada experimento independente (colunas), pelo teste de Dunnett $(P<0,05)$. C.V.: Coeficiente de variação. $\dagger$ Média de 12 plantas de cada tratamento avaliado. Data de inoculação: $1^{\circ}$ exp. (05/04/2017); $2^{\circ}$ exp. (01/11/2017); $3^{\circ} \exp .(02 / 02 / 2018)$.

No primeiro experimento, os eventos transgênicos TG4-4 e TG4-9, ambos expressando o gene $c s d l$, apresentaram menores valores de crescimentos médios diários de 
incidência e severidade de cancro cítrico da área abaixo da curva de progresso da doença, e diferiram significativamente em comparação ao valor de crescimento médio diário da doença em plantas não transgênicas (Testemunha 1) (Tabela 5). No segundo experimento, os valores de crescimento médio de incidência de cancro cítrico de nove eventos transgênicos (HS1; HS9; HS11; HS12; HS13; HS33; HS36; HS38; HS48) que expressam o gene d4e1 e de oito eventos transgênicos (TG3-16; TG3-19; TG4-3; TG4-4; TG4-6; TG4-9; TG4-33; TG4-37) que expressam o gene $c s d l$ diferiram significativamente em relação às plantas não transgênicas. Os eventos transgênicos (HS1; HS9; HS11; HS33; HS36; HS38; TG4-4; TG4-6; TG4-9; TG4-37), por sua vez, também apresentaram menores valores de crescimentos médios diários de severidade da AACPD e diferiram significativamente em relação às plantas não transgênicas (Tabela 5).

No terceiro experimento, quatro eventos transgênicos (HS1; HS9; HS12; HS13) expressando o gene $d 4 e 1$ e oito eventos transgênicos (TG3-14; TG3-16; TG3-19; TG4-2; TG44; TG4-6; TG4-9; TG4-11) expressando o gene csdl apresentaram menores valores de crescimento médio diário de incidência da doença e diferiram significativamente em comparação aos valores das plantas não transgênicas. Os menores valores de severidade da AACPD foram observados nos eventos transgênicos TG3-16, TG4-4 e TG4-9, apresentando crescimentos médios diários de 0,027, 0,021 e 0,025, respectivamente, diferindo significativamente da média das plantas não transgênicas (Tabela 5).

\section{Inoculação por ferimentos}

Sete eventos-elite transgênicos (csd1: TG4-3; TG4-4; TG4-6; TG4-9; d4e1: HS-9; HS11; HS-33) foram selecionados de acordo com os melhores resultados obtidos nos experimentos de resistência à $X c c$, realizados anteriormente. As quantificações das populações bacterianas foram avaliadas após as inoculações, todas por ferimentos, em folhas de laranja 'Hamlin' realizadas, em três experimentos independentes. Os primeiros sintomas de cancro cítrico tornaram-se visíveis entre cinco a sete dias após a inoculação (DAI).

Na primeira inoculação, realizada em 10/05/2018, a população bacteriana das plantas não transgênicas (T1) foi superior em relação aos eventos transgênicos. Na última avaliação deste experimento, aos 21 DAI, todos os eventos transgênicos apresentaram reduções significativas em relação à população bacteriana de T1 (Figura 17I). No segundo experimento, instalado em 10/08/2018, apenas o evento transgênico (HS9) diferiu significativamente em 
relação as plantas não transgênicas (T1), aos 21 DAI, apresentando população bacteriana de 4,2 x $10^{6} \mathrm{UFC} \mathrm{ml}^{-1}\left(6,48 \log _{10}\right)$ (Figura 17II). No terceiro experimento, inoculado em 11/02/2019, as populações bacterianas de $\mathrm{T} 1$ foram superiores nos períodos avaliados em relação aos eventos transgênicos, sendo que, aos 21 DAI, todos as plantas transgênicas apresentaram diferenças significativas em relação a T1 (Figura 17III). Nos três experimentos, a população bacteriana atingiu a fase logarítmica, um a oito DAI, a fase estacionária, oito a 14 DAI, e a fase final da curva de crescimento bacteriano, 14 a 21 DAI.

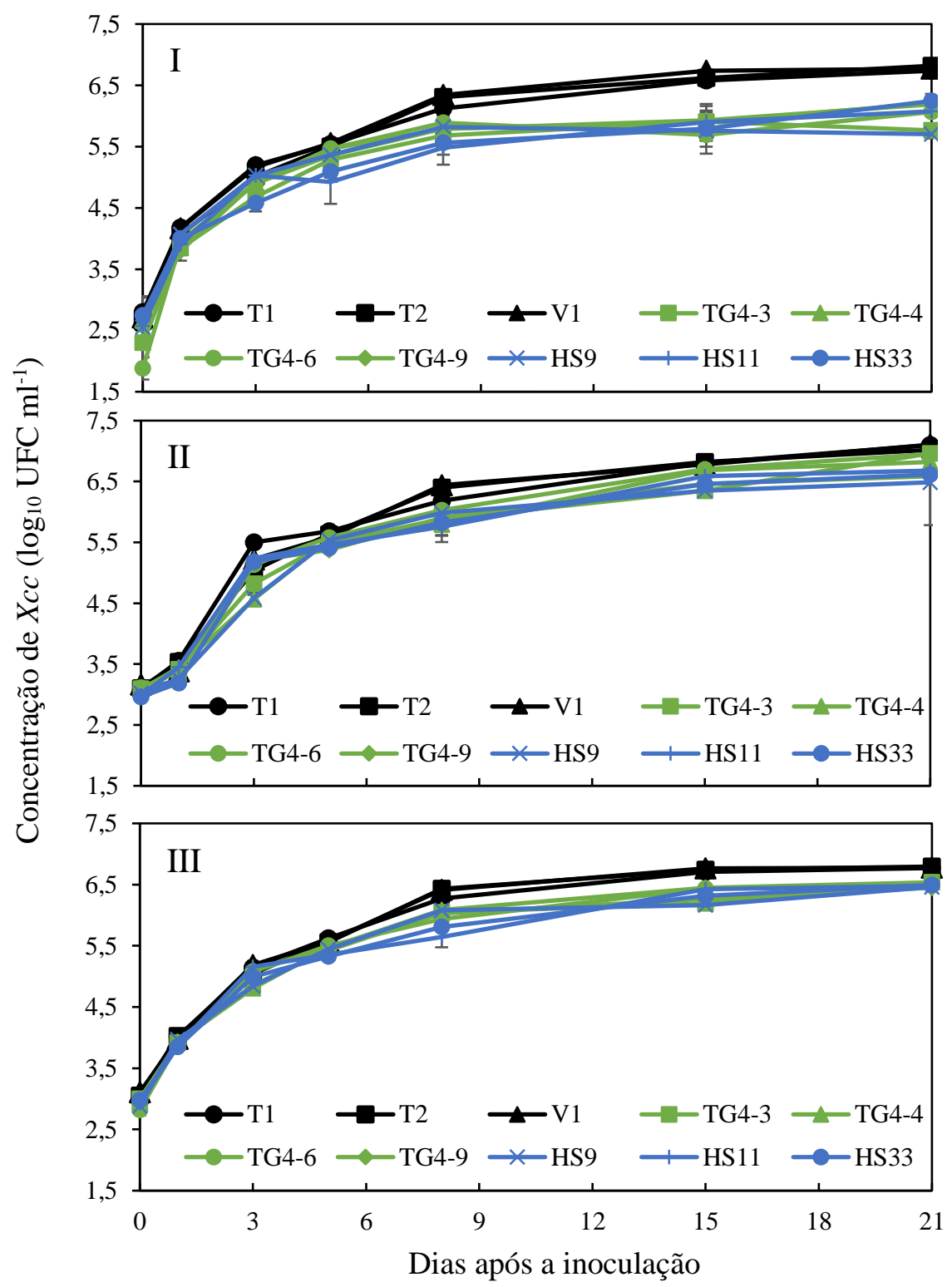

Figura 17. Quantificação da população bacteriana em lesões de folhas de laranja 'Hamlin' transgênicas e não transgênicas, inoculadas com Xcc, em três experimentos independentes (I, II, III). As barras representam o desvio padrão das médias. Média de três repetições biológicas. Data de inoculação: $1^{\circ} \exp .(10 / 05 / 2018) ; 2^{\circ} \exp .(10 / 08 / 2018) ; 3^{\circ} \exp .(11 / 02 / 2019)$. 
Os sintomas da doença registrados nas folhas foram restritos à área de inoculação, apresentando diferenças em relação às quantidades e tamanhos de lesões de cancro cítrico observados entre os eventos transgênicos e as plantas não transgênicas. Em continuação ao período de avaliação do experimento (35 dias), os números de lesões visíveis formadas após a inoculação com Xcc evoluíram continuamente, até estabilizarem aos 28 DAI. No total, 200 ferimentos foram analisados por evento quanto ao desenvolvimento de lesões, em dois experimentos independentes. Na última avaliação realizada, 35 DAI, as maiores quantidades de lesões formadas ocorreram nas plantas não transgênicas (Testemunha 1 e Testemunha 2), com 165 e 168 lesões, respectivamente (Tabela 6). O desenvolvimento das lesões de cancro cítrico foi atenuado nas folhas de todos os eventos-elite transgênicos, que variaram de 119 a 140 lesões, apresentando diferenças significativas, comparando-se com as plantas não transgênicas, 35 DAI (Tabela 6). Os eventos transgênicos HS33 e TG4-3 apresentaram sintomas visíveis de cancro cítrico em $60 \%$ e $61 \%$ dos ferimentos inoculados, respectivamente, indicando reduções de $30 \%$ na frequência da doença em relação à planta testemunha. Esses resultados foram consistentes aos encontrados no segundo experimento (Tabela 6).

Tabela 6. Número de lesões $\dagger$ de cancro cítrico formadas após inoculações, por ferimentos, em folhas de laranja 'Hamlin' transgênicas e não transgênicas, em Piracicaba, SP.

\begin{tabular}{|c|c|c|c|c|c|c|c|c|c|c|c|c|}
\hline \multirow{3}{*}{ Tratamentos } & \multicolumn{2}{|c|}{7 DAI } & \multicolumn{2}{|c|}{14 DAI } & \multicolumn{2}{|c|}{21 DAI } & \multicolumn{2}{|c|}{28 DAI } & \multicolumn{2}{|c|}{35 DAI } & \multicolumn{2}{|c|}{$\begin{array}{c}\text { Frequência } \\
\text { final }(\%)\end{array}$} \\
\hline & $1^{\circ}$ & $2^{\circ}$ & $1^{\circ}$ & $2^{\circ}$ & $1^{\circ}$ & $2^{\circ}$ & $1^{\circ}$ & $2^{\circ}$ & $1^{\circ}$ & $2^{o}$ & $1^{\circ}$ & $2^{\circ}$ \\
\hline & exp. & exp. & exp. & exp. & exp. & exp. & exp. & exp. & exp. & exp. & exp. & exp. \\
\hline Testemunha 1 & 18 & 12 & 68 & 65 & 110 & 98 & 158 & 148 & 165 & 157 & 83 & 78 \\
\hline Testemunha 2 & 20 & 14 & 56 & 57 & 98 & 92 & 164 & 156 & 168 & 165 & 84 & 82 \\
\hline Vetor vazio 1 & 12 & 12 & 61 & 55 & 107 & 97 & 171 & 151 & 171 & 159 & 86 & 79 \\
\hline HS9 & 8 & 7 & 42 & 37 & $88 *$ & 78 & 139 & 125 & $140 *$ & $127 *$ & 70 & 63 \\
\hline HS11 & $7 *$ & 8 & $38 *$ & 40 & 104 & $76^{*}$ & $131 *$ & $115^{*}$ & $131 *$ & $117 *$ & 66 & 58 \\
\hline HS33 & 9 & $5 *$ & 47 & 39 & $81 *$ & 78 & $119 *$ & $120 *$ & $119 *$ & $129 *$ & 60 & 64 \\
\hline \multirow{4}{*}{$\begin{array}{ll}\text { TG } & \text { TG-4 } \\
\text { TG4-6 } & \text { TG4-9 } \\
& \text { TG }\end{array}$} & 8 & $5 *$ & 51 & 43 & 101 & 99 & $120 *$ & $114^{*}$ & $122 *$ & $122 *$ & 61 & 61 \\
\hline & 10 & 9 & 46 & $32 *$ & 96 & 88 & $126^{*}$ & $119^{*}$ & $131 *$ & $135^{*}$ & 66 & 67 \\
\hline & $7 *$ & $5^{*}$ & $42 *$ & 37 & $74 *$ & 78 & $124 *$ & $108^{*}$ & $126^{*}$ & $118^{*}$ & 63 & 59 \\
\hline & $5 *$ & 7 & $34 *$ & $33 *$ & 99 & $75^{*}$ & $131^{*}$ & $104 *$ & $132 *$ & $125^{*}$ & 66 & 62 \\
\hline
\end{tabular}

*Difere significativamente em relação à média das plantas não transgênicas (Testemunha 1), pelo teste de Dunnett $(P<0,05)$, em cada coluna. $†$ Somatória de lesões formadas de um total de 200 ferimentos $(25$ folhas por tratamento avaliado). A frequência final da formação de lesões de cancro cítrico é expressa como (número total de lesões / total de ferimentos) x 100. Data de inoculação: $1^{\circ} \exp .(10 / 05 / 2018) ; 2^{\circ}$ exp. $(10 / 08 / 2018)$. 
No primeiro experimento, as áreas médias das lesões formadas 35 DAI variaram de $1,25 \mathrm{~mm}^{2}$ a 2,70 mm² entre as plantas de laranja 'Hamlin' analisadas. Entretanto, as áreas de lesões induzidas por $X c c$ em plantas não transgênicas, foram superiores às áreas das lesões dos demais eventos transgênicos, avaliados 35 DAI (Figura 18). As áreas médias das lesões dos eventos transgênicos (HS9; HS11; HS33; TG4-3; TG4-4; TG4-6; TG4-9) diferiram significativamente em relação com as lesões de (T1), variando de $1,25 \mathrm{~mm}^{2}$ a $1,77 \mathrm{~mm}^{2}, 35$ DAI (Figura 18I). Esses resultados foram consistentes aos encontrados no segundo experimento (Figura 18II). Os resultados dessas avaliações correlacionam-se com as análises de resistência à doença, sugerindo que estes eventos-elite transgênicos selecionados são, de forma consistente, menos suscetíveis à infecção por Xcc. 

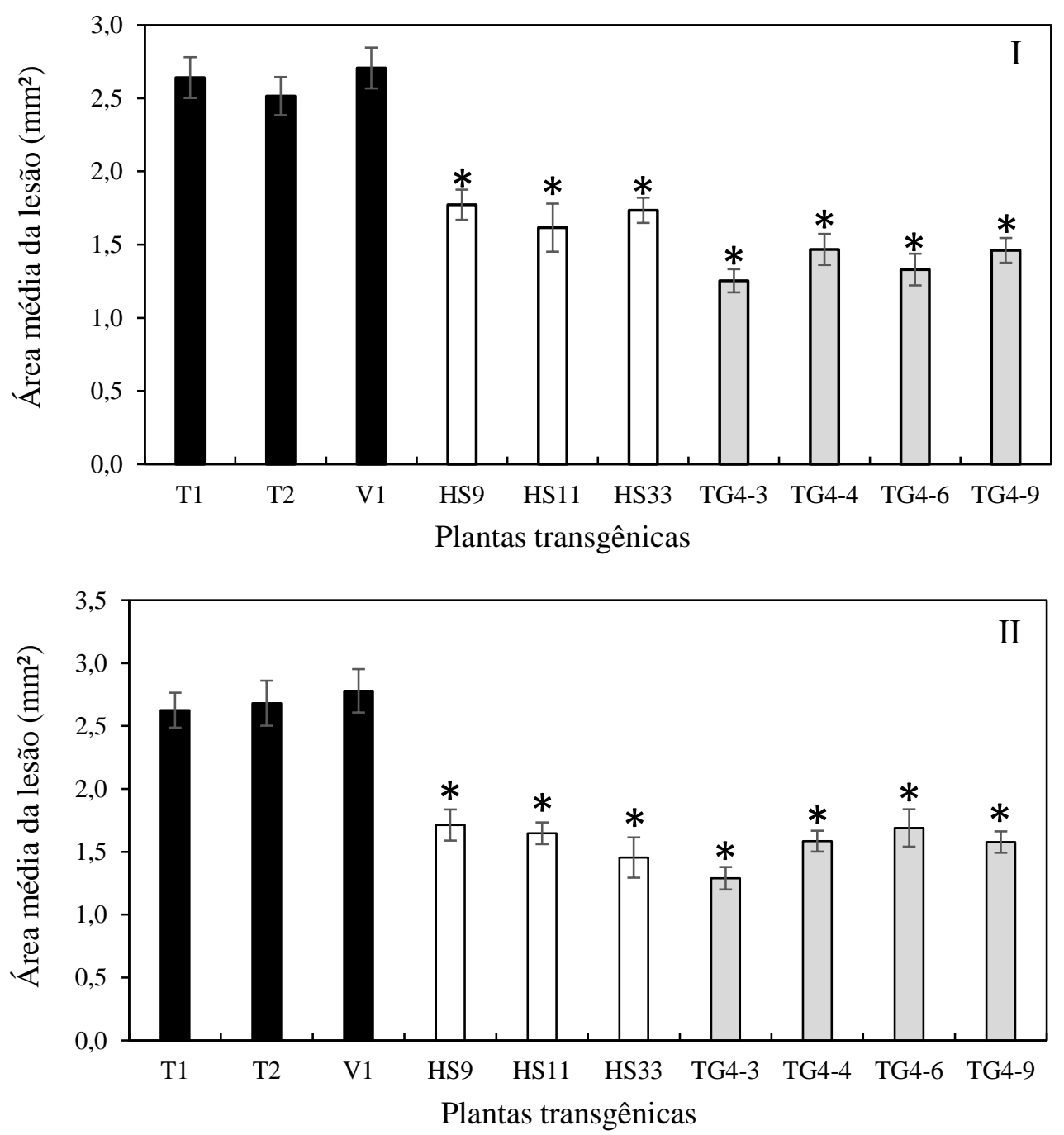

Figura 18. Área média das lesões de cancro cítrico em folhas de laranja 'Hamlin' transgênicas e não transgênicas, inoculadas com Xcc, em dois experimentos independentes, 35 DAI. *Difere significativamente em relação à média das plantas não transgênicas (T1), pelo teste de Dunnett $(P<0,05)$. As barras representam o desvio padrão das médias. Data de inoculação: $1^{\circ} \exp .(10 / 05 / 2018) ; 2^{\circ} \exp .(10 / 08 / 2018)$.

Microscopia de fluorescência: detecção de Xcc

Análises de microscopia de epifluorescência realizadas em amostras de folhas de plantas não transgênicas demonstraram que as bactérias, quando inoculadas por aspersão, não ocorreram em um padrão uniforme de distribuição nas superfícies das folhas, porém, os locais mais frequentes de penetração e posterior colonização foram através de estômatos da face abaxial (Figura 19A e B). Após a entrada das bactérias no interior do tecido foliar, modificações estruturais ocorreram principalmente nos espaços intercelulares, ativando os mecanismos de defesa das plantas, na tentativa de evitar a multiplicação do patógeno. A presença de Xcc em folhas de laranja doce induziu a formação de pústulas, ocasionadas pela proliferação celular do patógeno que causou rupturas das camadas epidérmicas (Figura 19C e D). Adicionalmente, a 
hipertrofia e a hiperplasia do parênquima lacunoso pareceu ser a principal causa de formação de pústulas. Entretanto, essas alterações anatômicas também serviram como barreiras físicas na tentativa de evitar a progressão do patógeno para outros locais do tecido (Figura 19E a H). 

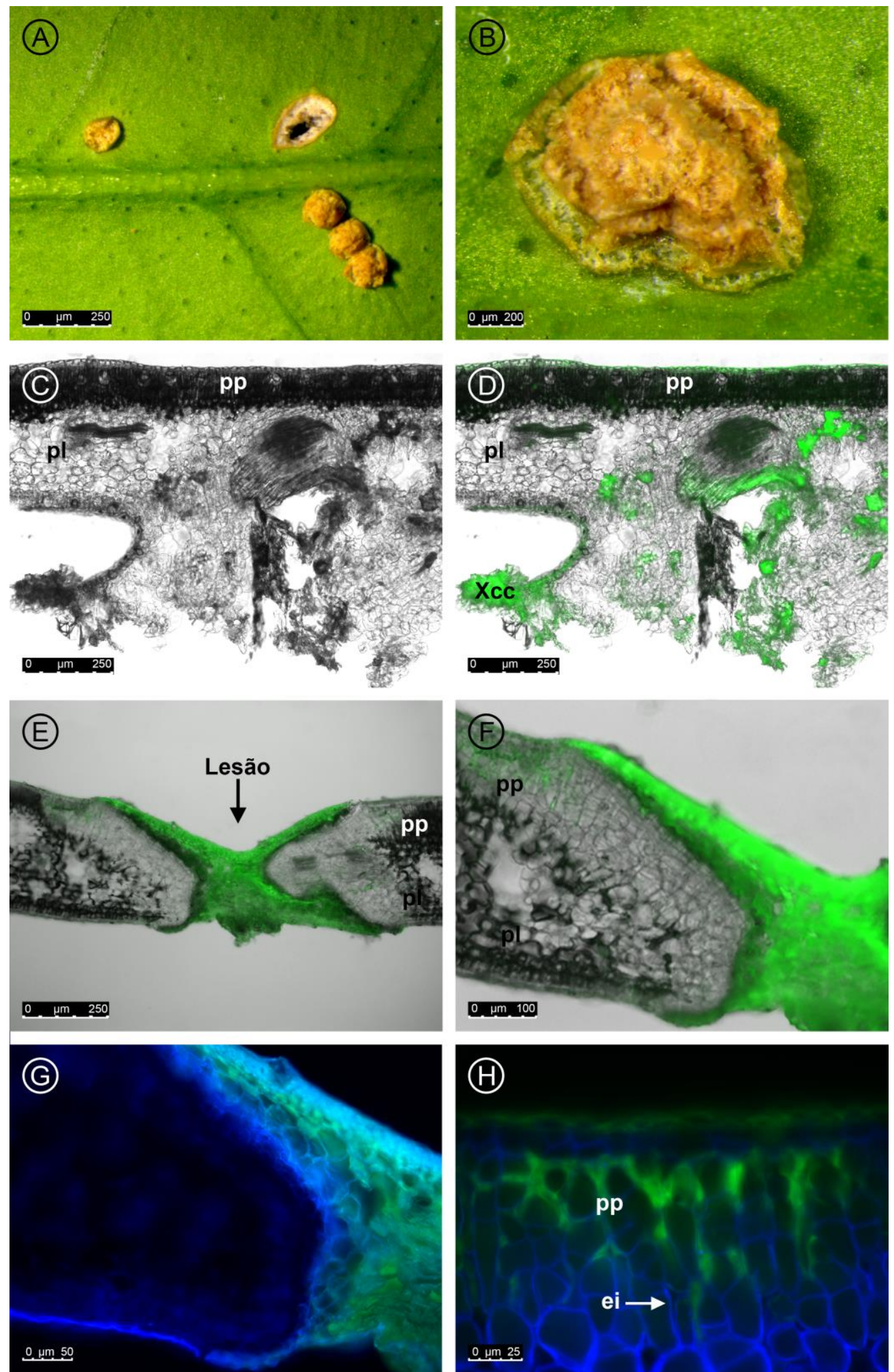

Figura 19. Sintomas de cancro cítrico em folhas de laranja 'Hamlin' não transgênicas. (A e B) Formação de pústulas na face abaxial da folha, 16 DAI. (C e D) Seção transversal da lesão anterior, com destaque para a detecção da $X c c \_G F P$ através da microscopia de epifluorescência. Notase o rompimento da epiderme. (E e F) Seção transversal do tecido foliar com destaque para a hipertrofia e hiperplasia do mesofilo. A seta indica a área necrosada, 30 DAI. (G e H) Detalhes da penetração da bactéria, formação de células hipertrofiadas e degradação da parede celular, corada com Calcofluor White. pp: parênquima paliçádico, pl: parênquima lacunoso, ei: espaço intercelular. 
A Xcc é responsável pela produção de exopolissacarídeos, proteases, lipases e pectinases que contribuem para a formação dos sintomas através da degradação das paredes celulares e de outros componentes (GABRIEL et al., 1989). Com o extravazamento do conteúdo celular, ocorre um aumento da quantidade de água e de nutrientes disponíveis no interior dos tecidos infectados, favorecendo a multiplicação das bactérias nos espaços intercelulares, induzindo a formação de lesões, conforme o observado na figura $19 \mathrm{H}$.

De acordo com análises de microscopia de epifluorescência, as lesões necróticas que ocorreram nas plantas transgênicas apresentaram similaridades anatômicas em relação às lesões observadas nas plantas não transgênicas, embora os sintomas tenham sido quantitativamente menos graves em alguns eventos transgênicos, como demonstrado anteriormente. Entretanto, além da quantidade reduzida do número de lesões formadas, observou-se através de cortes histológicos em folhas dos eventos-elite transgênicos, que a penetração da bactéria ocorreu de uma maneira mais lenta, embora presente em grande quantidade, evidenciado pela formação de biofilmes, na superfície abaxial das folhas, 30 DAI (Figura 20A, B, C). Esses resultados foram consistentes entre os eventos-elite transgênicos analisados nos três experimentos independentes, todos inoculados por aspersão.

Aparentemente, em algumas folhas de plantas transgênicas, as bactérias apresentaram maior resistência à entrada e posterior colonização do parênquima lacunoso, uma vez que as células do mesofilo sofreram intensas hipertrofias e hiperplasias na tentativa de contenção ao ataque do patógeno (Figura 20D, E, F). Destaca-se ainda que, a formação de biofilme de Xcc em superfícies foliares somente foi visualizada em plantas trangênicas menos suscetíveis à infecção, apresentando resultados consistentes entre os experimentos anatômicos realizados. A formação de camada bacteriana na superficie foliar, sem a apresentação de lesões visíveis, após 30 dias de inoculação, e a tentativa de conter e minimizar a presença de Xcc no tecido vegetal, sugerem um suposto mecanismo de defesa das plantas transgênicas ao ataque do patógeno (Figura 20G, H, I). Os resultados obtidos em eventos-elite transgênicos, através de avaliações de incidência e severidade da doença, corroboram os resultados das análises anatômicas, indicando desenvolvimentos de sintomas visuais mais lentos e menos agressivos quando comparados às plantas não transgênicas. 

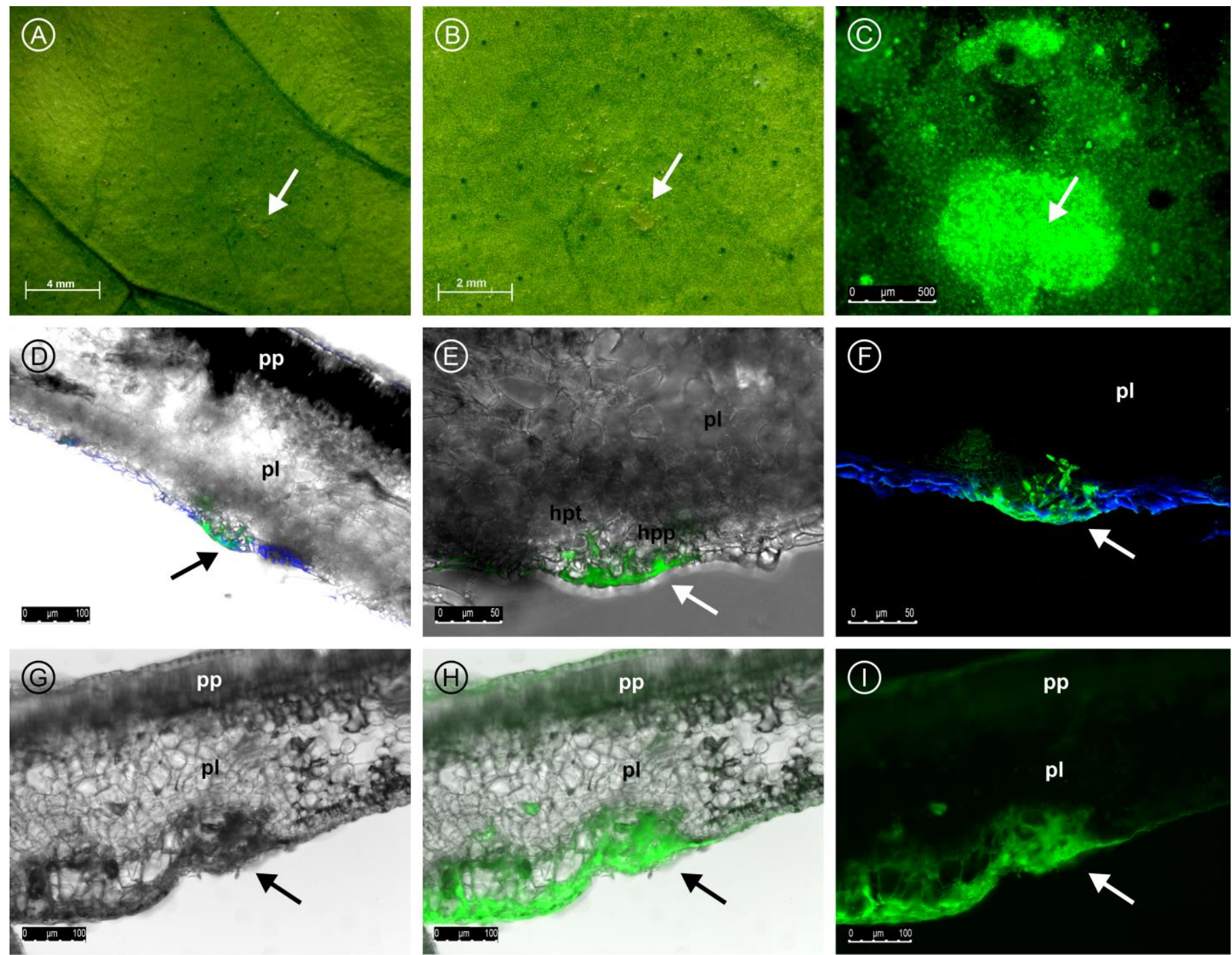

Figura 20. Presença de biofilme de $X c c_{-}$GFP na superfície abaxial das folhas do evento-elite transgênico (TG4-9), 30 DAI. (A e B) Setas indicam a presença de bactéria. (C) Detalhe da região em destaque na foto anterior, observada através da microscopia de epifluorescência. (D, E, F) Seção transversal do tecido foliar (biofilme de $X c c$ ), com o início da penetração e colonização da bactéria nos espaços intercelulares. Nota-se a hipertrofia (hpt) e hiperplasia (hpp) das células do parênquima lacunoso na tentativa de retardar a colonização no tecido foliar. (G, H, I) Processo de penetração, degradação da parede celular e perda do espaço extracelular livre. pp: parênquima paliçádico, pl: parênquima lacunoso.

Detecção de calose

Amostras de segmentos foliares de plantas transgênicas e não transgênicas foram analisadas e comparadas, qualitativamente, em relação às alterações de deposição de calose na região inoculada com $X c c$, por ferimento, nos tecidos vegetais (Figura 21A, B, C). As amostras de folhas dos eventos-elite transgênicos expressando o gene csdl (TG4-4; TG4-6; TG4-9) e amostras de folhas de plantas não transgênicas (Testemunha 1 - T1) foram avaliadas 24, 48 e 72 horas após a inoculação (h.a.i.). Análises anatômicas de epifluorescência revelaram maiores quantidades de deposições de calose na região infectada por Xcc nos eventos transgênicos 
(Figura 21G, H, I), principalmente, 48 h.a.i., em comparação com as plantas testemunhas (não transgênicas) (Figura 21D, E, F), como o indicado pelos pontos azuis (Figura 21D a I). Os sintomas de cancro cítrico surgidos nestas plantas transgênicas também foram menos agressivos em relação às plantas não transgênicas, sugerindo o papel da calose na contribuição para a resistência à multiplicação do patógeno no mesofilo foliar, agindo como uma eficiente barreira física. Esses resultados foram consistentes entre os eventos transgênicos analisados, em três experimentos independentes.
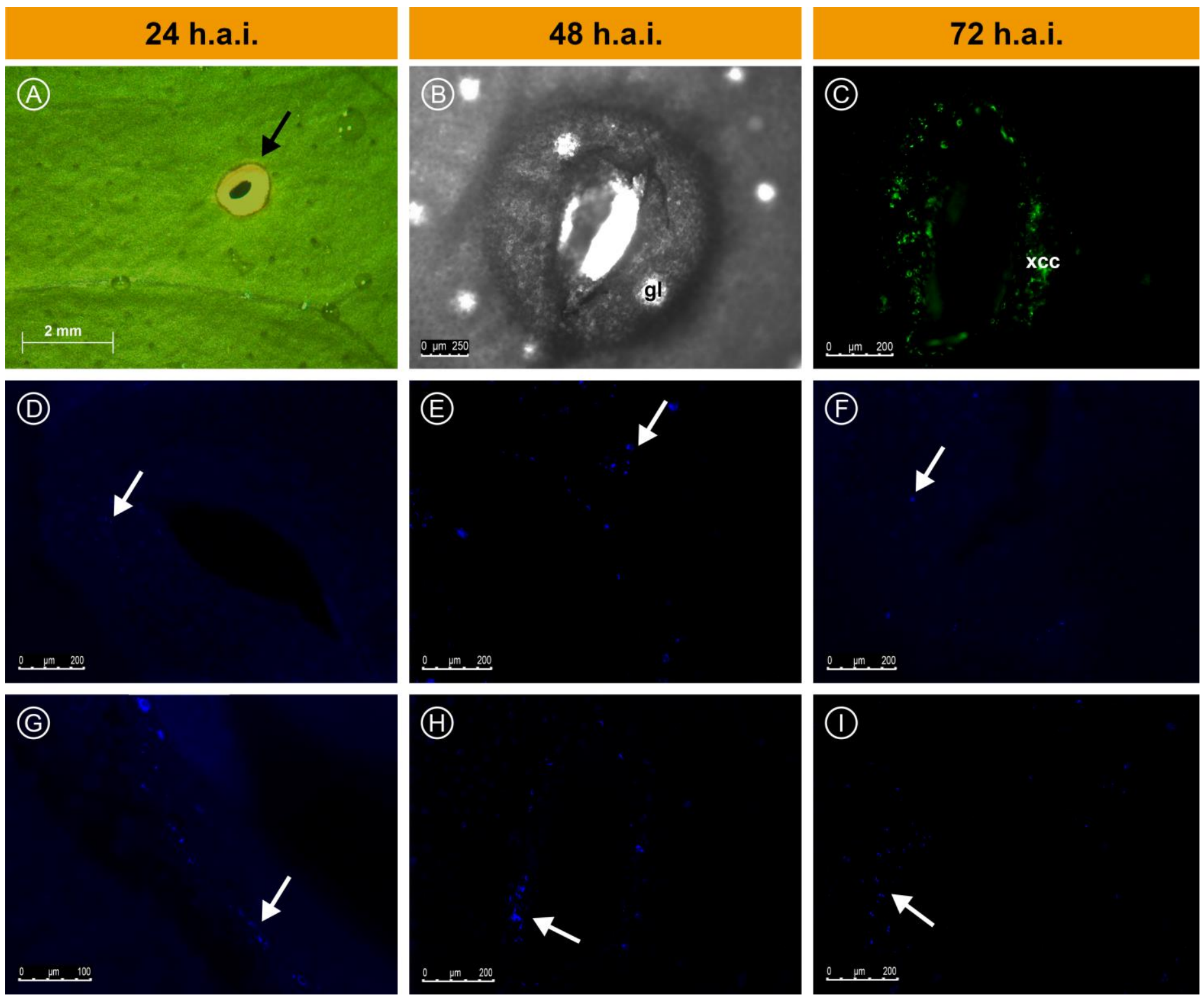

Figura 21. Deposição de calose em tecidos foliares de laranja 'Hamlin', 24, 48 e 72 horas após a inoculação (h.a.i.) com $X c c$, por ferimento (A, B, C). Microscopia de epifluorescência após o método de coloração com azul de anilina, em folhas de plantas não transgênicas (D, E, F). Plantas transgênicas, evento TG4-9 (G, H, I). A deposição de calose (setas brancas) ocorreu em todas as plantas inoculadas, porém em maior evidência na região de infecção do evento transgênico analisado. gl: glândula lisígena de óleo. 
Análise de expressão do gene csdl em laranjeiras doces

A quantificação do nível de expressão do gene $\operatorname{cs} d l$ foi avaliada por RT-qPCR para verificar a superexpressão induzida pelos mecanismos de defesa de plantas cítricas horas após a inoculação por Xcc. Os eventos transgênicos (HS9; TG4-6; TG4-9) foram selecionados para esta avaliação, pois, estes haviam demonstrado os melhores resultados de resistência à doença, em experimentos conduzidos anteriormente. O nível de expressão gênica no tempo Oh (quantificado antes da inoculação) das plantas não transgênicas (T1) foi utilizado como calibrador (Figura 22).

Os níveis de expressão do transgene csdl dos eventos TG4-6 e TG4-9 diferiram significativamente daqueles das plantas não transgênicas, em todos os períodos avaliados ( 0 ; 24; 48; 72 h.a.i. com Xcc), de acordo com as análises obtidas pelo software REST ${ }^{\circledR}$. Por outro lado, a expressão gênica do evento HS9 aumentou significativamente somente às 48 h.a.i., aumentando 4,2 vezes em relação às plantas não transgênicas. Nota-se também uma indução muito significativa registrada 48 h.a.i. do patógeno, sendo que esse padrão ocorreu em todos os eventos transgênicos TG4-6, TG4-9 e HS9, com aumentos de expressão na ordem de 4,5, 7,2 e 4,2 vezes, respectivamente, em relação à expressão gênica das plantas não transgênicas, de acordo com as análises obtidas pelo software REST ${ }^{\circledR}$ (Figura 22).

Os níveis de expressão do gene $c s d l$ não apresentaram alterações significativas na expressão gênica entre as plantas não transgênicas, em todos os períodos avaliados (Figura 22). 


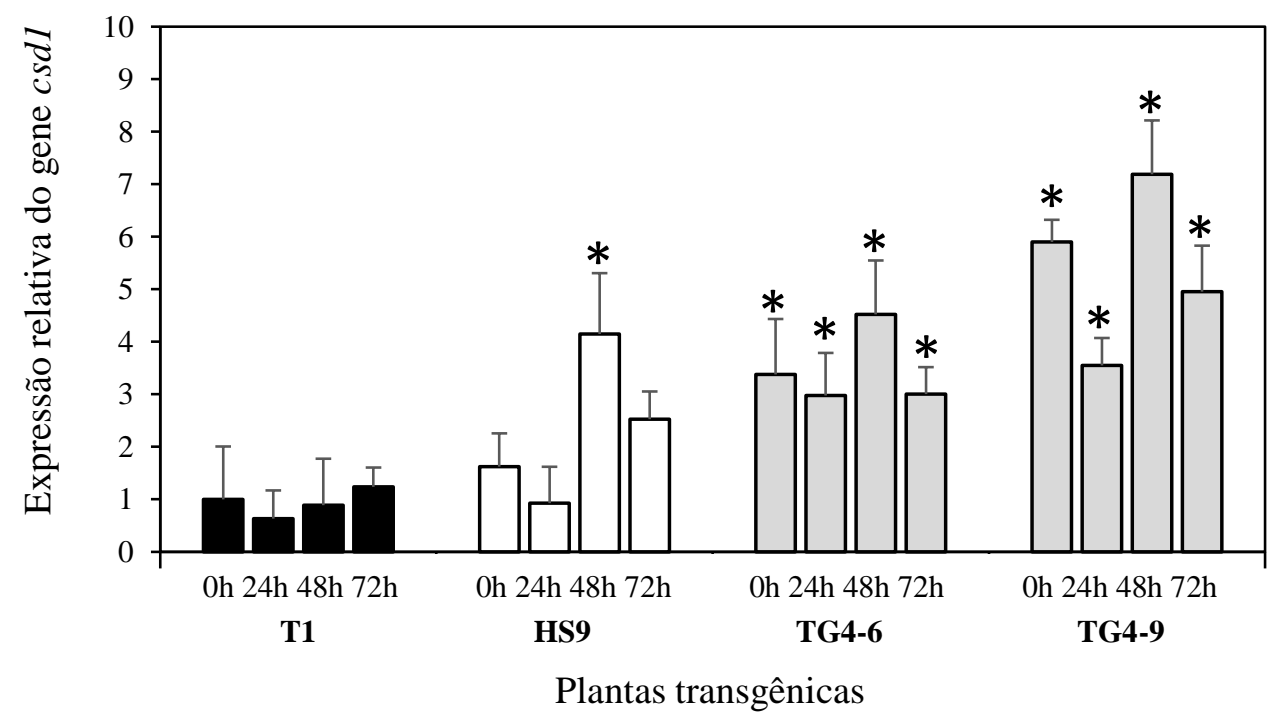

Figura 22. Expressão relativa do gene $c s d l$ em plantas transgênicas e não transgênicas de laranja 'Hamlin', 0, 24, 48, 72 h.a.i. de Xcc. *Difere significativamente pelo teste de Dunnett $(P<0,05)$ em relação ao nível de transcrição médio (em três replicatas biológicas) de cada evento, comparado com as plantas não transgênicas (T1), no tempo 0h. As barras indicam o desvio padrão das médias $(n=3)$.

\section{Resposta antioxidativa isoenzimática}

As quantificações do acúmulo de peróxido de hidrogênio e de atividades isoenzimáticas em resposta à explosão oxidativa foram avaliadas horas após a inoculação de $X c c$ em sete eventos-elite transgênicos e comparados com os resultados obtidos das plantas não transgênicas em cada período analisado.

De uma maneira geral, a concentração de malondialdeído (MDA), principal produto formado do processo de peroxidação lipídica, que estima indiretamente os danos celulares originados em resposta ao estresse oxidativo, aumentou em todas as plantas avaliadas, apresentando altas quantidades nas primeiras h.a.i. de Xcc (Figura 23). A concentração de MDA nos eventos transgênicos HS9, HS11 e TG4-9 diminuiu significativamente em relação às plantas não transgênicas (T1), 24 h.a.i., apresentando concentrações de 32,2 e 36,7 e 42,8 ๆmols $\mathrm{g}^{-1} \mathrm{MF}$, respectivamente. Esse mesmo comportamento foi observado nos eventos transgênicos HS11 e TG4-9, 48 h.a.i., os quais apresentaram reduções significativas nas concentrações de MDA (42,8 e 44,8 $\eta$ mols g ${ }^{-1} \mathrm{MF}$, respectivamente). Posteriormente, os eventos transgênicos registraram as menores concentrações de MDA, às 72 h.a.i., variando entre 38,7 a 53,4 ఛmols $\mathrm{g}^{-1} \mathrm{MF}$, apresentando reduções de 26,1 a 46,4 vezes em relação às concentrações das plantas não transgênicas (Figura 23). 


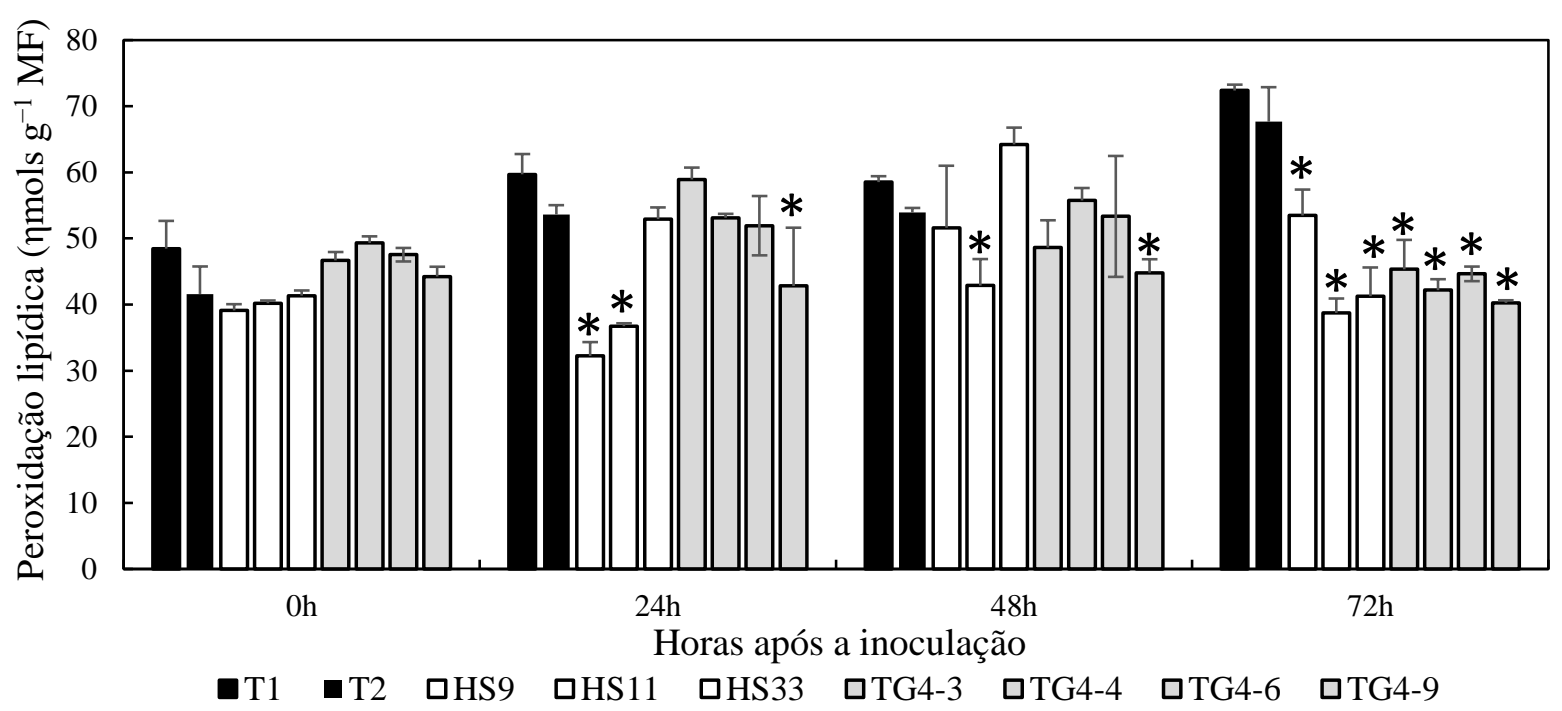

Figura 23. Concentração de malondialdeído (MDA) nos tecidos foliares de plantas transgênicas e não transgênicas de laranja 'Hamlin' inoculadas por Xcc. *Difere significativamente em relação à média das plantas não transgênicas (T1), pelo teste de Dunnett $(P<0,05)$, em cada período avaliado. Os resultados representam a média de três repetições biológicas $(n=3)$ e as barras indicam o desvio padrão das médias.

Produção de peróxido de hidrogênio $\left(\mathrm{H}_{2} \mathrm{O}_{2}\right)$

Níveis mais elevados de peróxido de hidrogênio foram observados nos eventos transgênicos expressando o gene $c s d l$ em todos os períodos avaliados. Após a inoculação das plantas cítricas com $X c c$, as produções de $\mathrm{H}_{2} \mathrm{O}_{2}$, nos eventos transgênicos TG4-4, TG4-6 e TG49 sofreram aumentos significativos, principalmente, 48 h.a.i., em comparação com as plantas não transgênicas, atingindo picos de 12,6, 12,09 e 12,51 $\mu \mathrm{M} \mathrm{g}^{-1} \mathrm{MF}$, respectivamente (Figura 24). Na última avaliação realizada, 72 h.a.i., todos os eventos transgênicos expressando o gene csdl apresentaram maiores e significativas produções de $\mathrm{H}_{2} \mathrm{O}_{2}$, aumentando 39 a 48 vezes a quantidade desta espécie reativa de oxigênio em relação as plantas não transgênicas. 


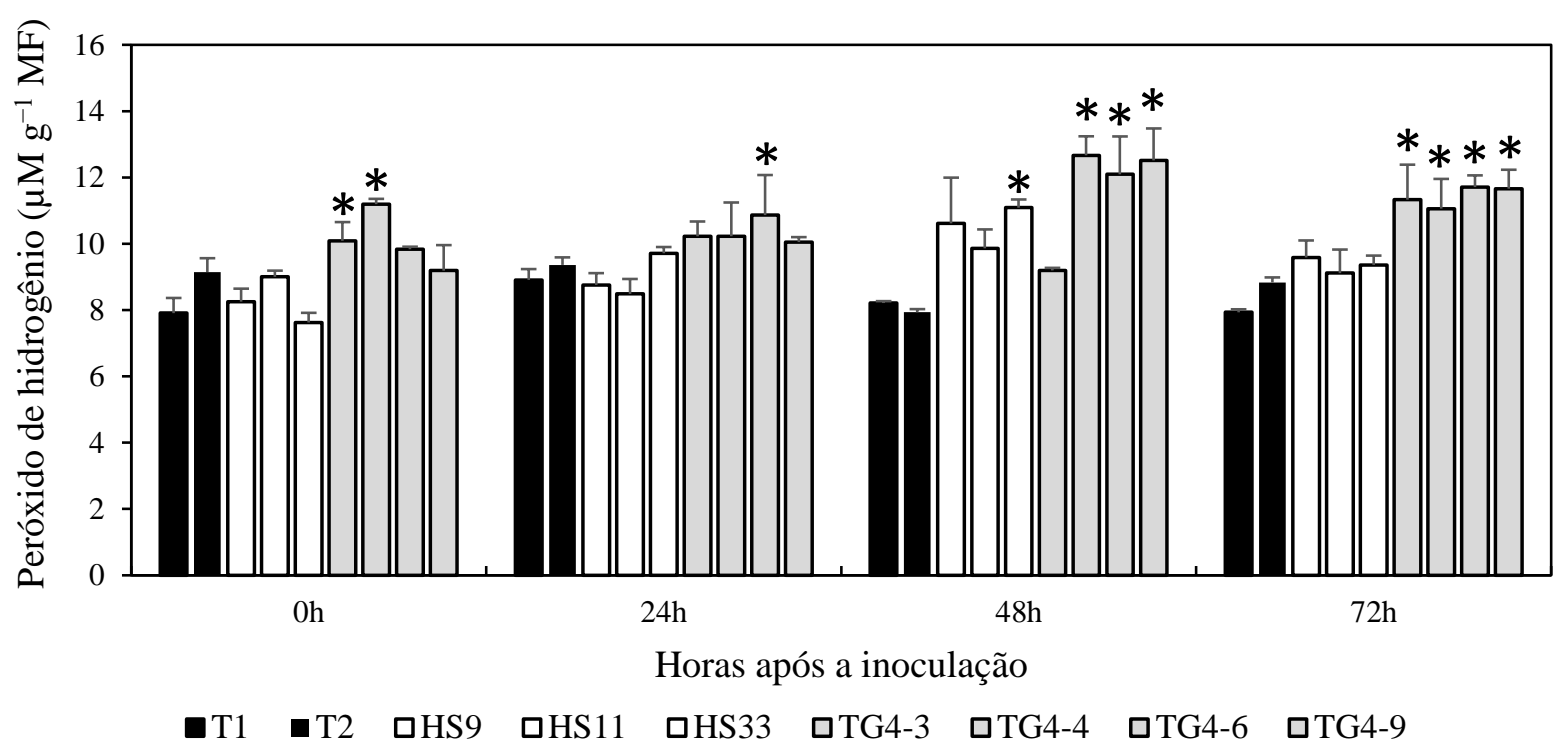

Figura 24. Quantificação de peróxido de hidrogênio $\left(\mathrm{H}_{2} \mathrm{O}_{2}\right)$ nos tecidos foliares de plantas transgênicas e não transgênicas de laranja 'Hamlin' inoculadas com Xcc. *Difere significativamente em relação à média das plantas não transgênicas (T1), pelo teste de Dunnett $(P<0,05)$, em cada período avaliado. Os resultados representam a média de três repetições biológicas $(n=3)$ e as barras indicam o desvio padrão das médias.

\section{Localização do acúmulo de peróxido de hidrogênio $\left(\mathrm{H}_{2} \mathrm{O}_{2}\right)$}

O acúmulo de peróxido de hidrogênio nos locais de infecção e nas regiões vizinhas foi detectado visualmente pelo uso de 3,3-diaminobenzidina (DAB), 12, 24 e 48 horas após a inoculação de $X c c$. Os resultados obtidos deste experimento foram semelhantes em todos os eventos transgênicos analisados que expressaram o gene csdl (TG4-3, TG4-4, TG4-6 e TG49). A quantidade acumulada de peróxido de hidrogênio no evento transgênico (TG4-9) foi superior em relação à da planta não transgênica, em todos os períodos avaliados (Figura 25). Com 12 h.a.i., todas as folhas avaliadas já apresentavam manchas marrons na região de inoculação. No entanto, neste mesmo período, o evento transgênico não apresentou diferenças significativas em relação ao diâmetro e a área representada pelo acúmulo de $\mathrm{H}_{2} \mathrm{O}_{2}$, corada pelo DAB, comparando-se com as plantas testemunhas. O padrão de coloração foi observado em maior intensidade e abundância, 24 e 48 h.a.i., no evento transgênico TG4-9, sugerindo que essas plantas possam ter acumulado maiores quantidades de $\mathrm{H}_{2} \mathrm{O}_{2}$ em relação às plantas não transgênicas (Figura 25). Este mesmo evento transgênico também apresentou diâmetro e área corada pelo reagente maiores significativamente, 24 h.a.i. (2,5 e 2,25 mm, respectivamente) e 48 h.a.i. (4,6 e 3,06 $\mathrm{mm}^{2}$, respectivamente), em comparação à testemunha, que se manteve com valores constantes nos períodos avaliados. Nenhuma resposta visual foi detectada em folhas 
inoculadas com solução tampão fosfato, indicando que a formação de $\mathrm{H}_{2} \mathrm{O}_{2}$ seja consequência da interação planta-patógeno.

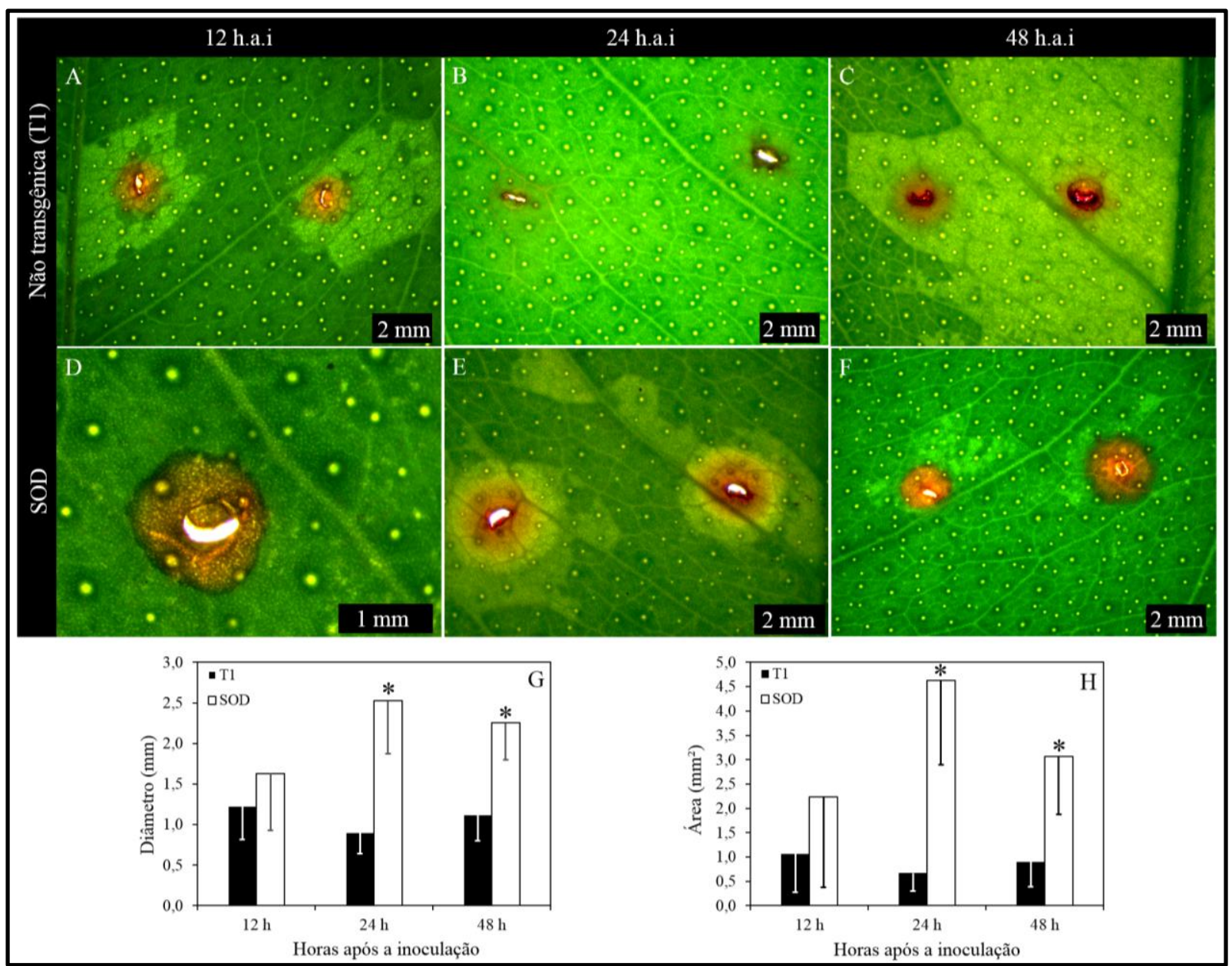

Figura 25. Localização de peróxido de hidrogênio $\left(\mathrm{H}_{2} \mathrm{O}_{2}\right)$ nos tecidos foliares de plantas transgênicas e não transgênicas de laranja 'Hamlin' 12, 24 e 48 h.a.i. com Xcc. Área corada pelo reagente DAB em folhas de plantas não transgênicas $(\mathrm{A}, \mathrm{B}, \mathrm{C})$ e folhas do evento transgênico TG4-9 (D, E, F). Quantificação do diâmetro e área dos locais de acúmulo de $\mathrm{H}_{2} \mathrm{O}_{2}$. *Difere significativamente em relação à média das plantas não transgênicas (T1), pelo teste de Dunnett $(P<0,05)$, em cada período avaliado. As barras representam o desvio padrão das médias $(\mathrm{n}=20)$.

Atividade de SOD

Todas as plantas analisadas apresentaram aumento da atividade da SOD em resposta à infecção por Xcc. Constatou-se rápido aumento na atividade de SOD após a inoculação, principalmente, nos eventos transgênicos que expressam o gene $c s d 1$. Os primeiros picos das atividades totais de SOD nos eventos TG4-3, TG4-4 e TG4-6 foram observados 48 h.a.i. (20,6; 21,2; 22,7 Unidades SOD $\mathrm{mg}^{-1}$ de proteína $\mathrm{min}^{-1}$, respectivamente), e revelaram aumentos de $27 \%, 30 \%$ e $40 \%$, respectivamente, em relação aos valores das plantas não transgênicas (Figura 
26). O segundo pico mais alto da atividade da SOD para estes mesmos eventos transgênicos foi observado 72 h.a.i. (20,1; 19,2; 19,4 Unidades SOD mg ${ }^{-1}$ de proteína $\mathrm{min}^{-1}$, respectivamente). As atividades totais de SOD nas plantas não transgênicas permaneceram relativamente constantes durante todos os períodos avaliados. Os eventos transgênicos que expressam o gene d4e1 não apresentaram níveis significativos de atividades de SOD em relação às plantas testemunhas (não transgênicas) (Figura 26).

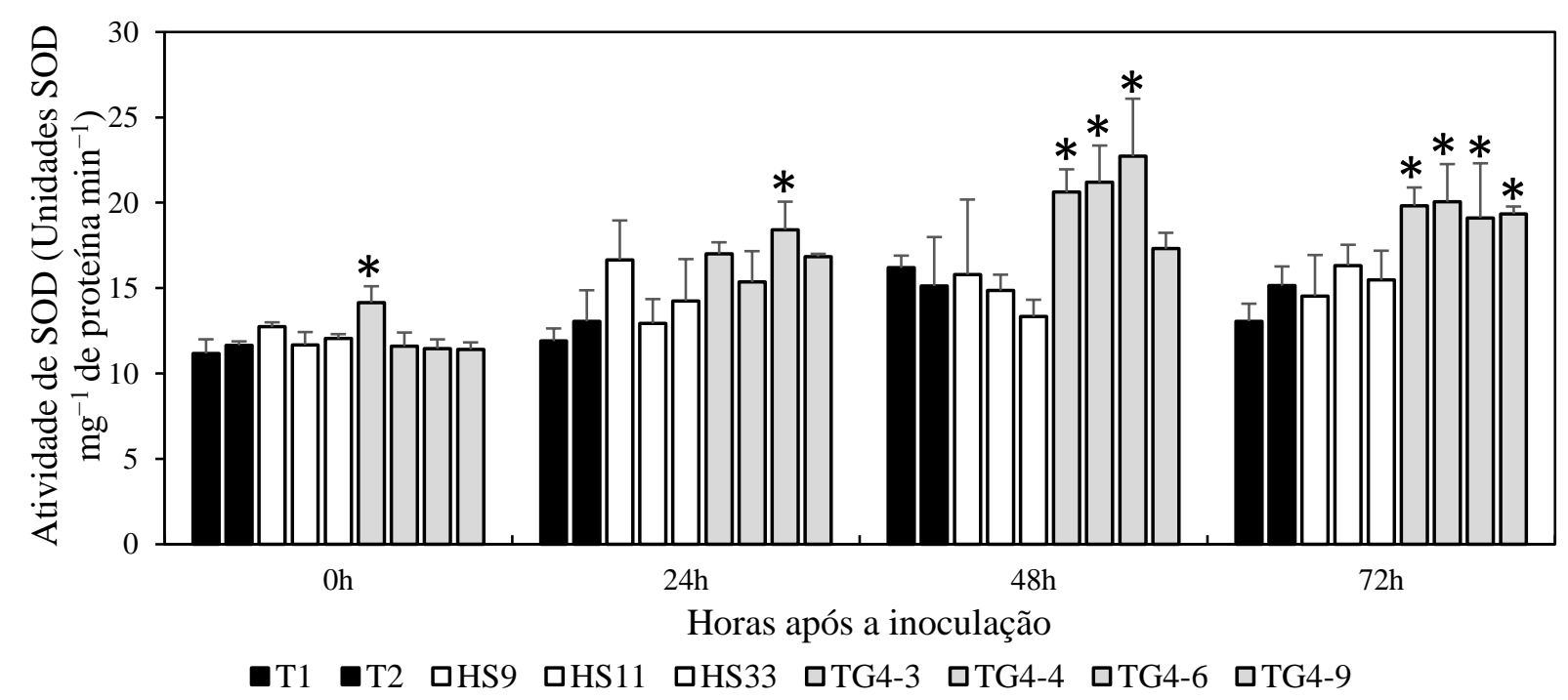

Figura 26. Atividade de SOD nos tecidos foliares de plantas transgênicas e não transgênicas de laranja 'Hamlin' inoculadas por $X c c$. *Difere significativamente em relação à média das plantas não transgênicas (T1), pelo teste de Dunnett $(P<0,05)$, em cada período avaliado. Os resultados representam a média de três repetições biológicas $(n=3)$ e as barras indicam o desvio padrão das médias.

Eletroforese em gel de poliacrilamida não-desnaturante (PAGE) e revelação de gel de SOD

A atividade de SOD em PAGE não-desnaturante em amostras de folhas cítricas revelou a presença de até duas isoformas distintas nas plantas transgênicas que expressam o gene $\operatorname{csd1}$. As caracterizações de isoformas de SOD nos eventos transgênicos TG4-3, TG4-4, TG4-6 e TG4-9 revelaram que as bandas induzidas nas amostras foram a Cu/Zn-SOD e MnSOD, em todos os períodos avaliados (Figura 27). Vale ressaltar que as bandas correspondentes às isoformas $\mathrm{Cu} / \mathrm{Zn}$-SOD nas amostras de plantas não transgênicas (T1) e nas plantas transgênicas que expressam o gene $d 4 e 1$ (HS9; HS11; HS33) não foram evidenciadas em nenhum período de avaliação, sendo detectada apenas a banda correspondente à isoforma MnSOD (Figura 27). 


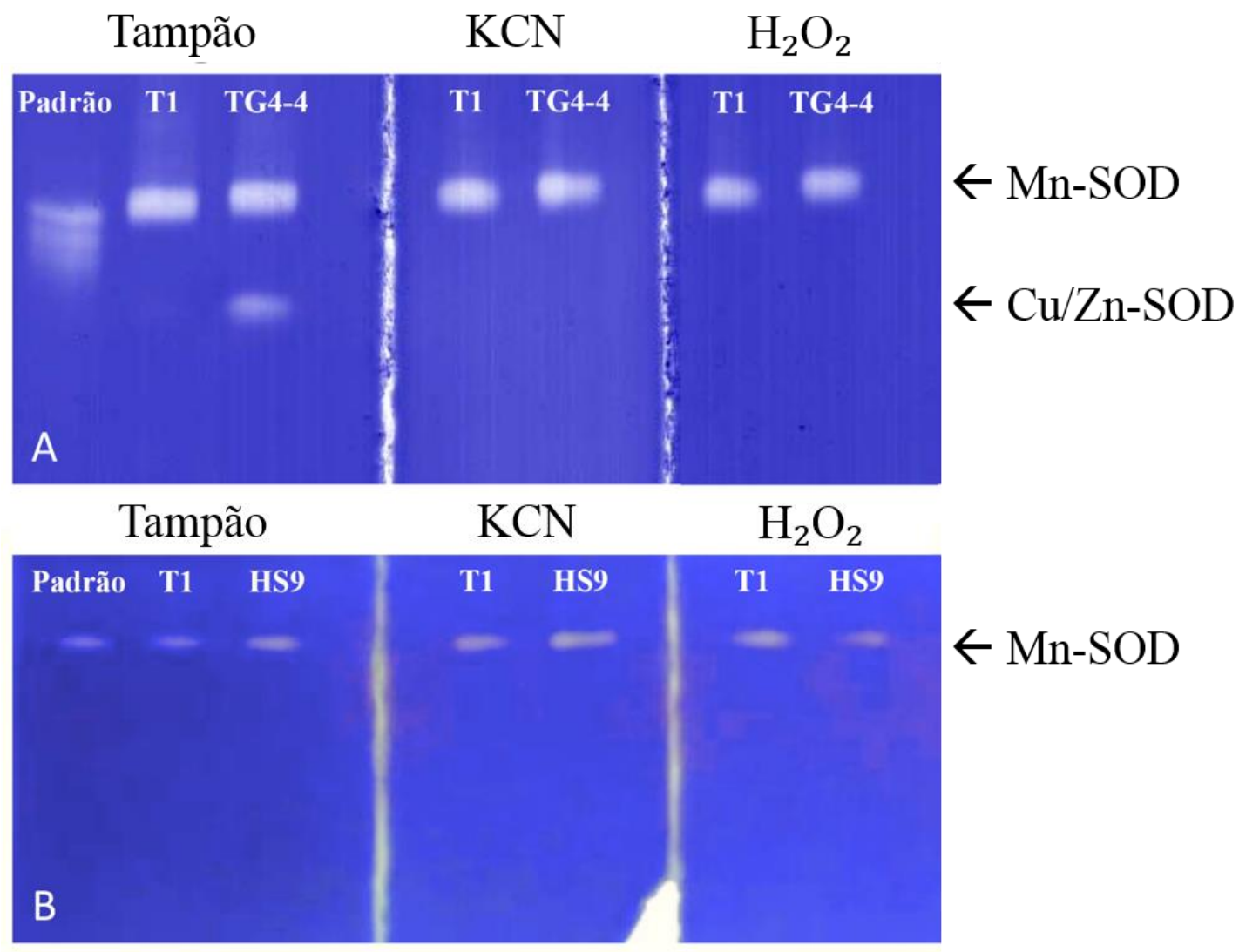

Figura 27. Caracterização de isoformas de SOD em PAGE não-desnaturante em tecidos foliares de plantas transgênicas e não transgênicas de laranja 'Hamlin' inoculadas por Xcc. (A) Amostras de folhas de plantas não transgênicas (T1) comparadas com plantas transgênicas (TG4-4) que expressam o gene csdl. Destaque para a formação de duas bandas correspondentes às isoformas Mn-SOD e Cu/Zn-SOD. (B) Amostras de folhas de plantas não transgênicas (T1) comparadas com plantas transgênicas (HS9) que expressam o gene $d 4 e 1$. Destaque para a formação de apenas uma banda correspondente à isoforma Mn-SOD. Mn-SOD é resistente a ambos os inibidores. Fe-SOD é resistente ao KCN e inibida por $\mathrm{H}_{2} \mathrm{O}_{2}$. $\mathrm{Cu} / \mathrm{Zn}-\mathrm{SOD}$ é inibida por ambos os inibidores.

Atividade de catalase (CAT)

As atividades de catalase sofreram poucas oscilações nos períodos avaliados em todos os eventos transgênicos e não transgênicos analisados, e não apresentaram diferenças significativas entre os tratamentos (Figura 28). 


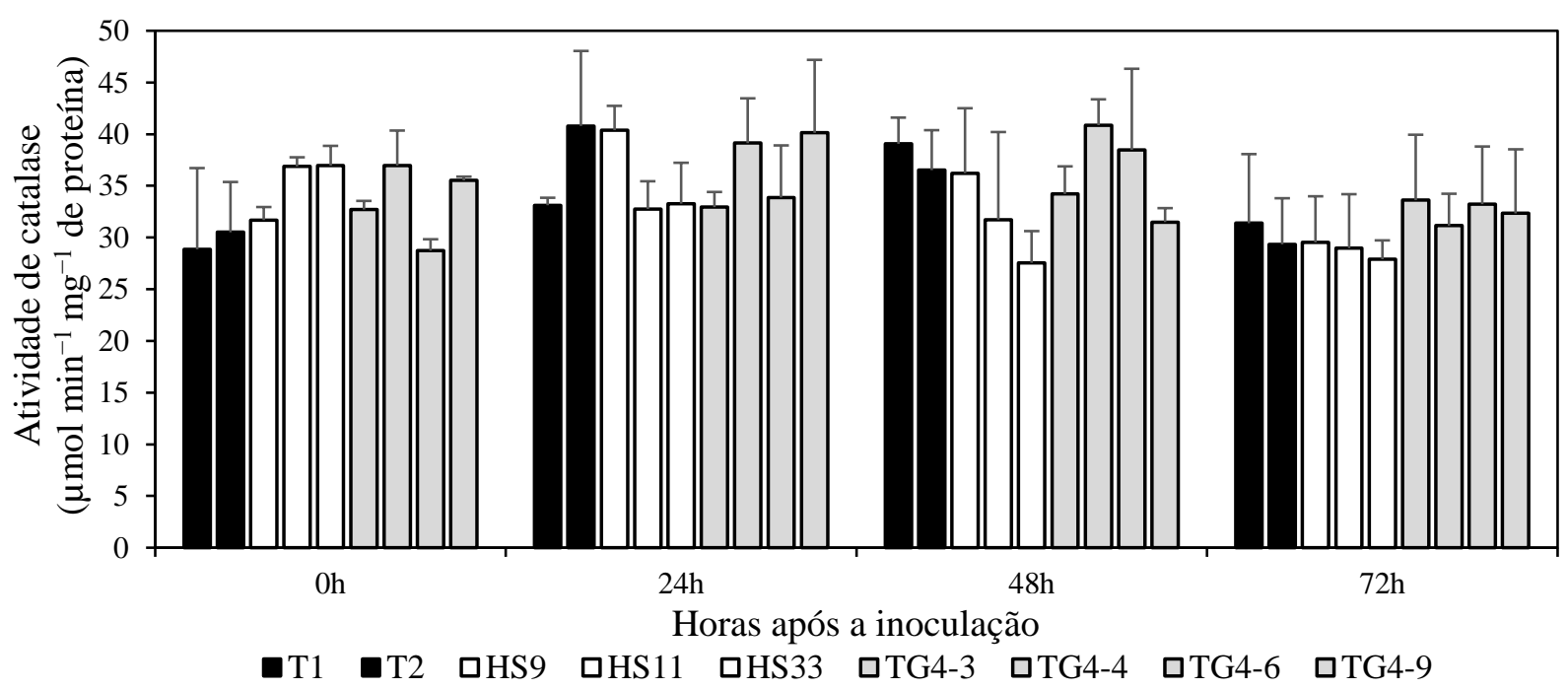

Figura 28. Atividade de catalase nos tecidos foliares de plantas transgênicas e não transgênicas de laranja 'Hamlin' inoculadas por Xcc. Os resultados representam a média de três repetições biológicas $(n=3)$ e as barras indicam o desvio padrão das médias.

\section{Glutationa peroxidase}

A atividade da glutationa peroxidase não apresentou diferenças significativas entre os eventos transgênicos e às plantas não transgênicas, em todos os períodos avaliados. As menores concentrações desta enzima antioxidante observadas nas amostras das plantas cítricas foram no tempo 0h (Figura 29).

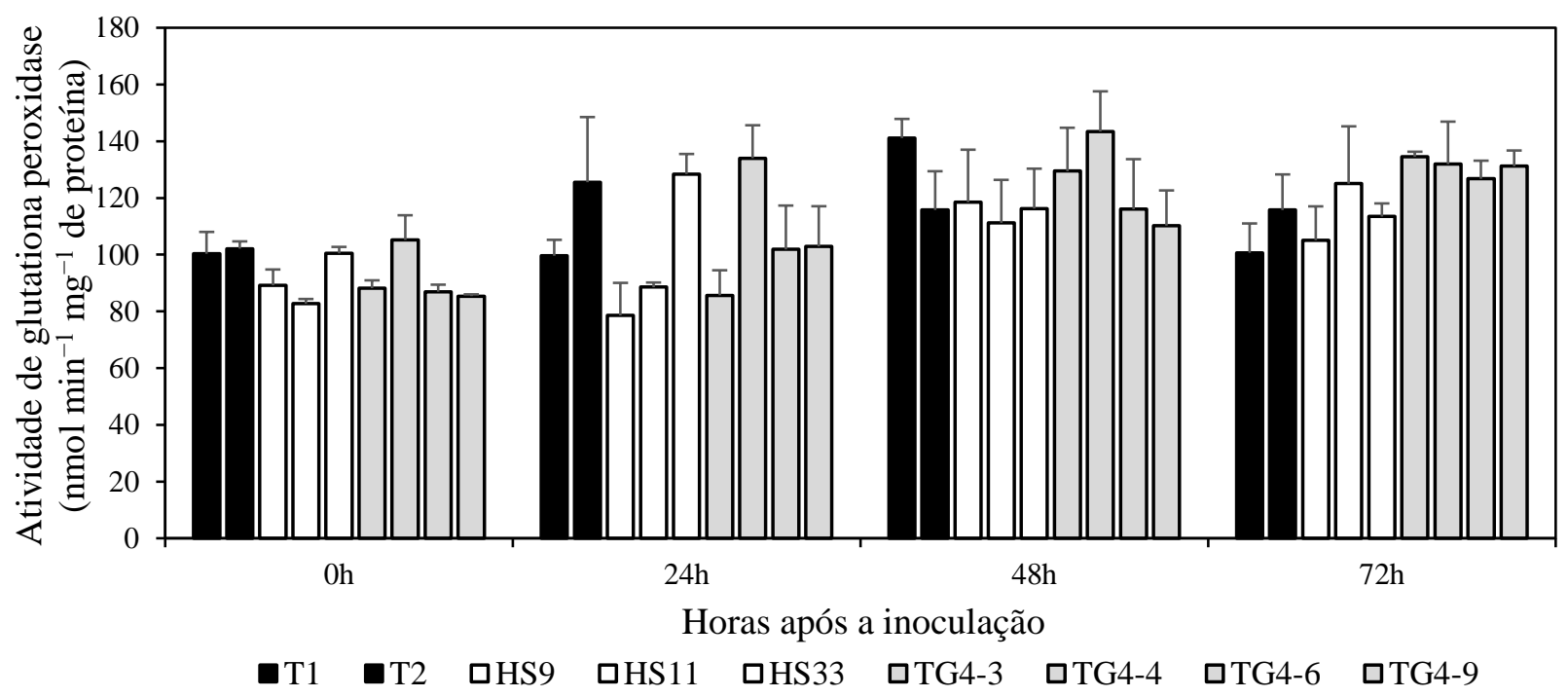

Figura 29. Atividade de glutationa peroxidase nos tecidos foliares de plantas transgênicas e não transgênicas de laranja 'Hamlin' inoculadas por Xcc. Os resultados representam a média de três repetições biológicas $(n=3)$ e as barras indicam o desvio padrão das médias. 


\section{Atividade antimicrobiana in vitro}

A atividade antimicrobiana in vitro do extrato proteico de plantas matrizes de laranja 'Hamlin' expressando o gene $d 4 e 1$ foi avaliada e quantificada após a incubação com suspensões de $X c c$ e o posterior plaqueamento da solução. O extrato proteico obtido das plantas não transgênicas foi utilizado como controle. Os resultados do experimento representam a média de três repetições biológicas. Os extratos proteicos dos eventos transgênicos (HS9, HS12, HS33 e HS36) inibiram significativamente o crescimento bacteriano em relação às plantas não transgênicas, apresentando concentrações médias de 4,7 x $10^{4} \mathrm{UFC} \mathrm{ml}^{-1}\left(4,41 \log _{10}\right), 2,2 \times 10^{4}$ UFC ml $l^{-1}\left(4,35 \log _{10}\right), 1,8 \times 10^{4} \mathrm{UFC} \mathrm{ml}^{-1}\left(4,25 \log _{10}\right)$ e $2,9 \times 10^{4} \mathrm{UFC} \mathrm{ml}^{-1}\left(4,46 \log _{10}\right)$, respectivamente, após quatro horas de incubação (Figura 30).

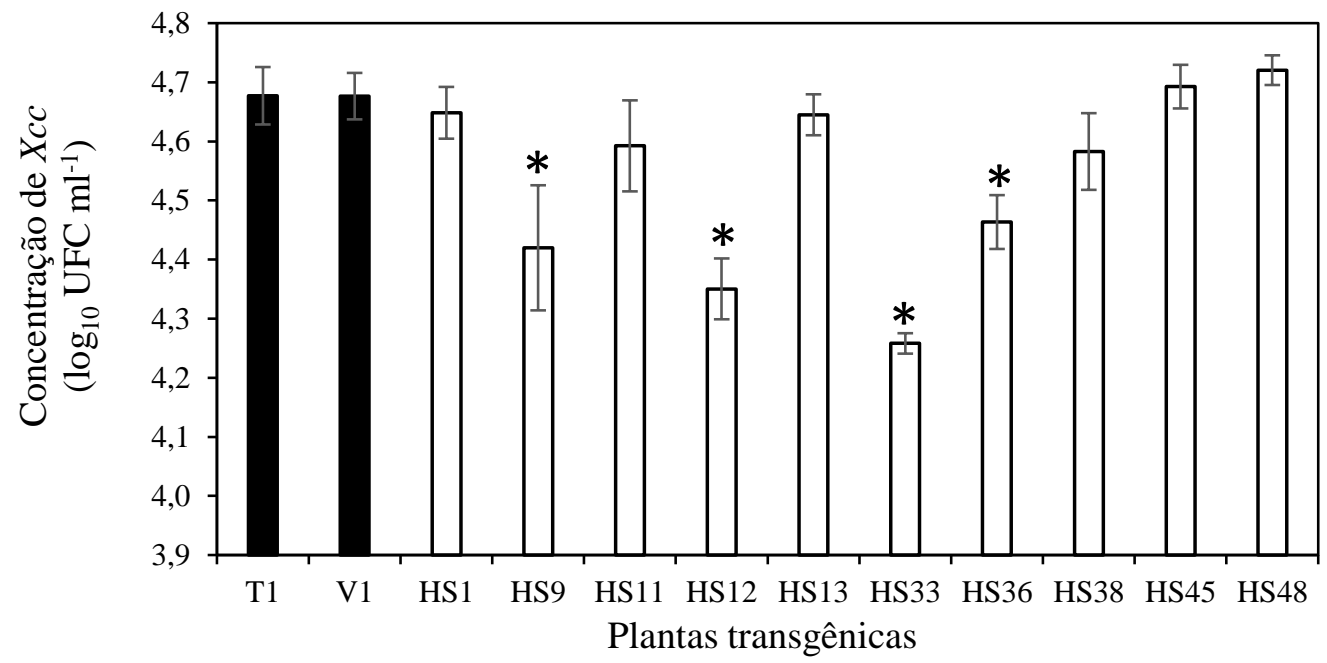

Figura 30. Atividade antimicrobiana in vitro do extrato proteico de plantas transgênicas de laranja 'Hamlin', expressando o gene $d 4 e 1$, e de plantas não transgênicas de laranja 'Hamlin' após a incubação com suspensões de Xcc. *Difere significativamente em relação à média da planta não transgênica (T1), pelo teste de Dunnett $(P<0,05)$. Os resultados representam a média de três repetições biológicas $(n=3)$ e as barras indicam o desvio padrão das médias. 


\section{DISCUSSÃO}

Este trabalho fornece informações sobre as reações das plantas transgênicas de laranja 'Hamlin' expressando o gene $c s d l$ ou expressando o gene $d 4 e 1$, após a infecção por Candidatus Liberibacter asiaticus ou Xanthomonas citri subsp. citri, sendo estes os patógenos associados às principais doenças que ameaçam diversas regiões produtoras de citros do mundo (GMITTER, 2016; BELASQUE JR et al., 2005). Até o presente momento, não existem espécies cítricas resistentes, e todas as variedades comerciais de laranjas doces cultivadas no Brasil são suscetíveis à infecção destes patógenos (MACHADO; CRISTOFANI-YALY; BASTIANEL, 2011). Desta forma, os pacotes tecnológicos podem ser importantes reforços na busca por cultivares resistentes às doenças, uma vez que diversos genes podem ser utilizados na transformação genética de plantas, tornando-se uma solução eficaz na obtenção de plantas transgênicas, com o uso de genótipos desejáveis (DUTT et al., 2012; BAFFANA et al., 2011).

Duas construções gênicas promissoras utilizadas na obtenção de plantas transgênicas de laranja doce resistentes às principais doenças bacterianas de citros foram empregadas e avaliadas neste trabalho, sendo, um gene envolvido na resposta de defesa das plantas ou outro gene que atua como um potente peptídeo antimicrobiano. Alguns relatos demonstraram resultados satisfatórios na utilização de diferentes genes derivados de Poncirus trifoliata e de seus híbridos, associados à resistência de CLas, sugerindo possíveis envolvimentos na defesa das plantas contra esse patógeno (ALBRECHT; BOWMAN, 2012; FOLIMONOVA et al., 2009; BOWMAN, 2007). Dentre os genótipos desejáveis, as enzimas do grupo superóxido dismutase, em especial as de cobre e zinco ( $\mathrm{Cu}-\mathrm{Zn}$ SOD) possuem destaque, agindo como importantes e eficientes proteínas antioxidantes relacionadas à proteção e defesa de plantas contra estresses oxidativos (ALBRECHT; BOWMAN, 2012; BAFFANA et al., 2011; ELSTNER, 1991). Além disso, o uso de peptídeos antimicrobianos derivados das cecropinas também se tornam promissores no combate à CLas, principalmente, por sua elevada toxicidade contra importantes patógenos causadores de doenças em plantas (ZOU et al., 2016; ZHANG et al., 1995).

A expressão do gene $c s d l$ foi previamente avaliada em outros estudos transcricionais relativos ao patossistema HLB em plantas cítricas (MORAES, 2015; ALBRECHT; BOWMAN, 2012). Neste trabalho, a superexpressão do gene $c s d l$ foi induzida em todos os eventos transgênicos de laranja 'Hamlin', embora, tenha-se registrado grande variação na expressão de plantas contendo a mesma construção gênica, conforme os trabalhos realizados 
por Butaye et al. (2005). Entretanto, esta variação não está associada, necessariamente, ao número de inserções de cópias do transgene, e sim, à provável posição do transgene inserida no genoma (ELMAYAN; VAUCHERET; 1996). As expressões desses transgenes correlacionaram-se, parcialmente, com os resultados de quantificações de CLas presentes nos tecidos vegetais das plantas transgênicas. O evento transgênico (TG4-2), por sua vez, obteve um dos maiores níveis de expressão entre as plantas analisadas e, ao mesmo tempo, apresentou reduções significativas no título bacteriano, em comparação àquele da testemunha, seis meses após a inoculação.

Esses resultados podem explicar os possíveis atrasos na infecção e multiplicação das bactérias nas plantas transgênicas (TG3-16; TG4-2; TG4-3; TG4-28; TG4-37; HS11) que apresentaram diferenças significativas, indicando maior tolerância à $C$ Las, uma vez que essas plantas apresentaram menores títulos bacterianos e, em algumas, reduções dos sintomas visuais de HLB, seis meses após a inoculação. O resultado obtido do evento transgênico HS11 foi consistente aos valores encontrados por Zou et al. (2016), em estudos com laranjeiras doces transgênicas expressando o gene cecropin B. Além disso, os valores dos títulos bacterianos variaram amplamente entre os demais eventos transgênicos, nos três períodos avaliados. Esses resultados sugerem que os diferentes genótipos possam ter influenciado na multiplicação de CLas, indicando diferenças de populações bacterianas entre as plantas cítricas analisadas (COLLETA-FILHO et al., 2010; MARENGO, 2009). No entanto, a alta eficiência de transmissão de CLas por borbulhas infectadas também pode justificar as diferenças nas populações dos eventos transgênicos, interferindo, supostamente, na avaliação da resistência destes materiais transgênicos (TATINENI et al., 2008).

As análises de quantificação do título bacteriano, expressas em números de cópias da região 16S do rDNA de $C$ Las nas plantas cítricas não demonstraram reduções significativas ao longo dos 18 meses de avaliação, sugerindo que a temperatura não foi um fator que influenciou diretamente na taxa de infecção e multiplicação do patógeno, conforme os resultados de outros estudos que apresentam reduções na população bacteriana em períodos de elevadas temperaturas (COLLETA-FILHO et al., 2010; WANG et al., 2006). Diante disso, este trabalho propôs correlacionar os diferentes títulos bacterianos obtidos dos genótipos estudados com os distúrbios metabólicos que ocorreram após a infecção por CLas nos tecidos vegetais de plantas de laranja 'Hamlin', analisando assim, a deposição de calose nos elementos do tubo crivado, seguida pela desordem nutricional e a consequente redução da matéria seca de parte aérea e do 
sistema radicular (BOAVA; CRISTOFANI-YALY; MACHADO, 2017; ETXEBERRIA et al., 2009).

Em pesquisas envolvendo estudos de interação planta-patógeno, o acúmulo de calose nos elementos de tudo crivado e nas paredes celulares tem sido constantemente associado a uma das possíveis respostas de defesa de plantas contra a infecção de agentes patogênicos, atuando na tentativa de evitar a colonização do hospedeiro no tecido vegetal (OLIVEIRA et al., 2019; BOAVA; CRISTOFANI-YALY; MACHADO, 2017; LUNA et al., 2011; XIE et al., 2011; NAKASHIMA et al., 2003). Além disso, a calose está presente em diversos processos relacionados ao desenvolvimento de plantas superiores (CHEN; KIN, 2009). Entretanto, alguns trabalhos apontaram aspectos divergentes em relação aos mecanismos de defesa de plantas mediados pela ação da calose (BONNEMAIN et al., 2013; ELLINGER et al., 2013). Diante disso, a obstrução dos elementos de tubo crivado em decorrência do acúmulo de calose, em plantas de laranja doce infectadas, associada ao patossistema HLB, sugere que seu bloqueio possa representar um papel proeminente no comprometimento do transporte floemático em plantas cítricas, justificando o surgimento dos sintomas característicos da doença (OLIVEIRA et al., 2019). Neste estudo, as alterações de deposição de calose foram comparadas entre as plantas de laranja 'Hamlin' e, demonstrou-se que os eventos transgênicos apresentaram grandes depósitos do polissacarídeo no floema, principalmente, naqueles que possuíam menores populações bacterianas.

Contudo, o acúmulo excessivo de calose nos elementos de tubo crivado em plantas infectadas com HLB pode causar redução ou impedimento do funcionamento do floema, comprometendo o transporte e a mobilização de fotoassimilados entre os órgãos do vegetal (OLIVEIRA et al., 2019). Estas alterações fisiológicas podem estar relacionadas aos surgimentos dos sintomas característicos da doença, justificando assim, a indução de graves deficiências nutricionais, além de provocar a redução do crescimento das partes aéreas e do sistema radicular de plantas cítricas (KOH et al., 2012).

Após a infecção, a distribuição das bactérias em plantas cítricas ocorre por todos os tecidos que contenham floema, e provavelmente, o patógeno move-se bidirecionalmente com o fluxo de fotoassimilados das folhas para os órgãos vegetais consumidores de carboidratos, incluindo as raízes (LI et al., 2009; TATINENI et al., 2008). Neste sentido, os resultados deste trabalho revelaram que as plantas cítricas que apresentaram menores títulos bacterianos exibiram correlações positivas com valores de acúmulo de matéria seca da parte aérea e do 
sistema radicular, avaliadas 18 meses após a inoculação. O envolvimento direto da presença de CLas na redução da matéria seca do sistema radicular pode ser derivado da ação de um efetor bacteriano que causa a morte ou a inibição do crescimento de novas raízes, resultando em menores teores de biomassas (ANN et al., 2004; GRAHAM; MENGE, 1990). Esses resultados foram consistentes aos estudos que evidenciaram que o sistema radicular é o local mais comum da primeira detecção e multiplicação de $C$ Las em plantas cítricas, afetando drasticamente seu desenvolvimento (JOHNSON; BRIGHT; GRAHAM, 2014; TEIXEIRA et al., 2008; GOLDSCHMIDT; KOCK, 1996).

As desordens nutricionais são alterações fisiológicas e metabólicas decorrentes dos danos que a doença provoca no transporte de fotoassimilados e de elementos minerais em plantas cítricas infectadas por $C$ Las. De uma maneira geral, os resultados demonstraram que as plantas não transgênicas apresentaram menores concentrações de macronutrientes foliares em comparação às das plantas transgênicas, após a inoculação por CLas. As doenças de plantas podem reduzir drasticamente a disponibilidade, absorção ou distribuição dos nutrientes. Diante disso, alguns genótipos transgênicos apresentaram baixos teores foliares de $\mathrm{Ca}, \mathrm{Mg}$ e $\mathrm{S}$, e excessivas concentrações de $\mathrm{P}$ e $\mathrm{K}$, sendo que esses resultados foram consistentes aos encontrados por Malavolta et al. (2005). Os nutrientes desempenham um papel complexo nas interações entre as plantas e os patógenos. No entanto, dependendo do estado nutricional da planta, os elementos químicos podem afetar a resistência ou a tolerância dos vegetais aos patógenos (MARSCHNER, 2012). De acordo com os resultados deste trabalho, a deficiência acentuada de Ca observada nos eventos transgênicos pode ter prejudicado os mecanismos de defesa das plantas. Isso ocorre porque o Ca é responsável diretamente pela estabilização da lamela média da parede celular, além de estar envolvido em respostas de hipersensibilidade a infecções bacterianas (YANG et al., 2011). Além disso, segundo Marschner (2012), a diminuição na concentração de $\mathrm{Ca}$, constantemente observada em plantas infectadas por bactérias, foi correlacionada a um aumento na concentração de K, que por sua vez, em altos teores causa a redução nas concentrações de outros nutrientes. As deficiências em outros macronutrientes como S (HANEKLAUS et al., 2007) e Mg (JONES; HUBER, 2013) também estão associadas a maiores incidências de doenças de plantas.

Em experimentos complementares, análises por espectroscopia de fluorescência de raios $\mathrm{X}$ com feixe micrométrico $(\mu-\mathrm{XRF})$ foram realizadas para quantificar a distribuição espacial de macro e micronutrientes presentes no tecido foliar de plantas cítricas saudáveis e infectadas com $C$ Las. Devido à alta resolução espacial e sensibilidade analítica, o $\mu$-XRF 
apresenta-se como uma ferramenta promissora e amplamente utilizada para avaliações multielementares in vivo da distribuição de nutrientes em tecidos vegetais (AHMAD et al., 2011; REGVAR et al., 2011; LOMBI; SUSINI, 2009). Neste trabalho, o emprego do $\mu$-XRF fornece resultados pioneiros nas determinações dos elementos minerais presentes em folhas de laranjas doces infectas com HLB. Em geral, para os macronutrientes, os resultados indicaram uma distribuição espacial de $\mathrm{P}$ e $\mathrm{S}$ similares entre as folhas das plantas sem HLB e nas infectadas pela doença. Os micronutrientes também não sofreram grandes variações entre as plantas avaliadas. Os níveis de $\mathrm{K}$ e $\mathrm{Ca}$, por outro lado, apresentaram reduções consistentes nas folhas de plantas com HLB.

Apesar da escassez de resultados para esta cultura, as análises de $\mu$-XRF mostraram que as áreas próximas ao pecíolo foliar apresentam maiores intensidades de macronutrientes, conforme observados em estudos preliminares que atribuem esse fenômeno ao aumento da concentração de nutrientes nos feixes vasculares, e também à espessura de tais regiões, geralmente maiores do que as observadas no limbo foliar, podendo levar a obtenção de maiores sinais dos nutrientes investigados (MONTANHA et al., 2020; PROEBSTING; WARNER, 1952). Os resultados apontados pela espectroscopia de fluorescência por raios $X$ para os macronutrientes corroboram os resultados das análises químicas foliares, que também apresentaram teores superiores de $\mathrm{K}$ e Ca em relação aos teores de P e S. Os estudos utilizando $\mu$-XRF são capazes de fornecer resultados precisos em relação ao monitoramento da redistribuição de elementos a curtas distâncias em plantas vivas, permitindo assim, relacionálos com suas concentrações e adotar novas estratégias de manejos nutricionais.

O cancro cítrico, por sua vez, é uma das doenças mais destrutivas que afetam a produção de citros em todo o mundo. Diversos genes foram utilizados na transformação genética de plantas cítricas visando a resistência à $X c c$, apresentando reduções significativas na suscetibilidade ao cancro cítrico. Entre os genótipos desejáveis, destacam-se os genes que codificam as proteínas harpinas, o gene $M d S P D S 1$, o gene $X a 21$, além de eficientes peptídeos antimicrobianos codificados pelo gene cecropin B ou o gene attacin A (ZOU et al., 2016; FU et al., 2011; MENDES et al., 2010; BARBOSA-MENDES et al., 2009; BOSCARIOL et al., 2006).

Este trabalho demonstrou que sete eventos transgênicos (TG4-3; TG4-4; TG4-6; TG49; HS9; HS11: HS33) resultaram em reduções significativas na população de Xcc em comparação com as plantas não transgênicas, apresentando reduções de até $60 \%$ dos sintomas 
visuais de cancro cítrico. Essas plantas também resultaram em baixos crescimentos médios diários de incidência e severidade da área abaixo da curva da doença, em todas as avaliações realizadas. Apesar dos níveis de incidência e severidade de cancro cítrico apresentarem variações entre os genótipos em cada experimento, essas oscilações, aparentemente, não estão relacionadas às estações do ano e as consequentes condições climáticas de cada período. Esses resultados não apresentaram um padrão consistente que pudesse relacionar a influência dos fatores climáticos sobre o índice de infecção da doença, contrariando alguns estudos anteriores que sofreram grandes interferências (PALAZZO; MALAVOLTA Jr; NOGUEIRA, 1984; BEHLAU, 2006).

Além disso, a quantificação da área e o número de lesões formadas também evidenciaram reduções significativas na suscetibilidade à $X c c$ nestes eventos transgênicos, 35 DAI. Estas observações são fundamentais para ratificar a resistência destes genótipos à infecção por Xcc, uma vez que, a inoculação por ferimentos e a estimativa do diâmetro de lesões formadas são considerados sistemas eficientes, precisos e acurados nas avaliações de interações e resistência de plantas ao cancro cítrico (BELASQUE JR et al., 2008; VILORIA et al., 2004; GRAHAM et al., 1992; GARRAN, 1988).

$\mathrm{O}$ atraso observado no desenvolvimento dos sintomas visuais em alguns eventos transgênicos também sugere uma diminuição considerável na gravidade da doença. Esses resultados corroboram as análises de microscopia de epifluorescência que demonstraram que, aparentemente, em algumas folhas de plantas transgênicas, as bactérias apresentaram maior resistência à colonização do parênquima lacunoso, uma vez que as células do mesofilo, em especial as localizadas próximas à camara sub-estomática, sofreram intensas hipertrofias e hiperplasias na tentativa de contenção ao ataque do patógeno. Além disso, as análises evidenciaram o maior acúmulo de calose nos tecidos foliares de plantas transgênicas, sugerindo que a deposição do polissacarídeo foi uma resposta rápida e específica da parede celular durante a infecção por Xcc (YUN et al., 2006). Estudos anteriores de silenciamento de genes da calose sintase comprovaram o papel fundamental da calose na resistência de plantas cítricas à Xcc, demonstrando que, além disso, a goma xantana, principal exopolissacarídeo secretado pela bactéria, seria capaz de induzir a suscetibilidade ao patógeno pela supressão da deposição de calose (ENRIQUE et al., 2010; RIGANO et al., 2007; YUN et al., 2006).

Uma provável explicação para a resistência de alguns eventos transgênicos que demonstraram altas deposições de calose estaria relacionada à ação integrada de outras 
moléculas sinalizadoras de defesa, além da própria atividade desencadeada por enzimas antioxidantes, como o $\mathrm{H}_{2} \mathrm{O}_{2}$ (QUAN et al., 2008). Diante disso, observou-se que os níveis de expressão do gene csd1 nas plantas menos suscetíveis (TG4-6 e TG4-9) foram induzidos em até sete vezes, 48 horas após a inoculação de $X c c$, diferentemente do observado em plantas testemunhas. Esses resultados sugerem que o gene $\operatorname{csdl}$, relacionado ao sistema de defesa da planta, é induzido em quantidades insuficientes para restringir a multiplicação e disseminação do patógeno em genótipos suscetíveis (BOSCARIOL; TAKITA; MACHADO, 2016).

Para identificar o estresse oxidativo e as respostas das atividades isoenzimáticas geradas pelas plantas cítricas após a infecção de $X c c$, alguns parâmetros bioquímicos foram quantificados. Em condições de estresses abióticos e bióticos, as plantas produzem espécies reativas de oxigênio, produtos naturais do metabolismo, incluindo o radical superóxido $\left(\mathrm{O}_{2}^{-}\right)$, o peróxido de hidrogênio $\left(\mathrm{H}_{2} \mathrm{O}_{2}\right)$ e o radical hidroxila $(\mathrm{OH})$ (WOJTASZEK, 1997). A toxicidade das espécies reativas de oxigênio induz a ação do complexo arranjo dos mecanismos de desintoxicação, em especial os enzimáticos, que contribuem para evitar a dissipação de elétrons e causar maiores danos celulares (PAULY et al., 2006; GRATÃO et al., 2005). Como marcador biológico do estresse oxidativo, o MDA é um importante produto originado da oxidação de ácidos graxos poli-insaturados, e tem sido utilizado para determinar o grau de peroxidação lipídica (DEL RIO et al., 2005; RAEL et al., 2004). Os maiores conteúdos de MDA foram observados nas plantas não transgênicas, uma vez que a peroxidação lipídica inicia inúmeras reações em cadeia que produzem radicais livres, tornando-se tóxicos às células vegetais (GOBEL et al., 2003).

Os níveis de $\mathrm{H}_{2} \mathrm{O}_{2}$, que em excesso são tóxicos para as células vegetais e também para as células bacterianas, aumentaram e permaneceram constantes, em comparação com as plantas testemunhas. Picos acentuados de geração de $\mathrm{H}_{2} \mathrm{O}_{2}$ e de atividade total de SOD foram observados, ambos ocorridos 48 horas após a inoculação. Esta correlação revela um papel fundamental da atividade da enzima antioxidante na interação das plantas com a bactéria, uma vez que, maiores atividades da SOD proporcionam maiores dismutações dos radicais superóxidos, além de agir na disfunção metabólica celular e morte do patógeno (KUMAR; EBEL; ROBERTS, 2011; TERTIVANIDIS et al., 2004). Alguns estudos demonstraram que Xanthomonas spp. são naturalmente resistentes aos ânions superóxidos, mas são suscetíveis a $\mathrm{H}_{2} \mathrm{O}_{2}$, corroborando aos resultados isoenzimáticos obtidos neste trabalho (TONDO et al., 2010; CHAMNONGPOL et al., 1996; LOPRASERT et al., 1996). 
Gerações e acúmulos localizados de $\mathrm{H}_{2} \mathrm{O}_{2}$ nos tecidos foliares foram relatados em diversos estudos envolvendo interações entre plantas e patógenos (MEHDY, 1994). Trabalhos anteriores relataram que as áreas localizadas do tecido foliar com elevadas concentrações de $\mathrm{H}_{2} \mathrm{O}_{2}$ indicam maiores chances de intoxicação e supressão da população bacteriana (KUMAR; EBEL; ROBERTS, 2011; PENG; KUC, 1992). Os resultados deste trabalho apresentaram maiores concentrações e acúmulos de $\mathrm{H}_{2} \mathrm{O}_{2}$, após a utilização do reagente $\mathrm{DAB}$, nos eventos transgênicos que expressaram o gene $c s d 1$, em comparação com as plantas testemunhas.

A elevada atividade de SOD presente naqueles eventos transgênicos que apresentaram aumentos significativos em relação às plantas testemunhas sugere maior eficiência na remoção metabólica destes radicais superóxidos no metabolismo das plantas cítricas. Duas isoformas de SOD foram identificadas apenas nos tecidos dos eventos transgênicos que expressam o gene csdl, indicadas pelas bandas de $\mathrm{Cu} / \mathrm{Zn}-\mathrm{SOD}$ e de Mn-SOD. Esses resultados podem estar correlacionados à maior resistência destes genótipos à $X c c$, pois, a isoforma $\mathrm{Cu} / \mathrm{Zn}-\mathrm{SOD}$, além de atuar no apoplasto, pode contribuir diretamente para a defesa antioxidante associada com a proteção do cloroplasto (ALSCHER et al., 2002). As atividades das enzimas antioxidantes da catalase e da glutationa peroxidase não apresentaram diferenças significativas entre as plantas avaliadas; entretanto, possuem papéis fundamentais na quebra e remoção de $\mathrm{H}_{2} \mathrm{O}_{2}$ das células vegetais, sendo consideradas indispensáveis para a desintoxicação das espécies reativas de oxigênio (DUBEY, PANDEY, 2011; AZEVEDO et al., 1998).

Em complemento a essas análises, a atividade antimicrobiana in vitro do extrato proteico de plantas transgênicas que expressaram o gene $d 4 e l$ foi avaliada após a infecção de Xcc. Embora os ensaios in vitro nem sempre expressem as reais eficácias dos peptídeos antimicrobianos no organismo do hospedeiro, essas avaliações podem fornecer valiosas informações sobre a atividade potencial desses compostos contra os patógenos (OSUSKY et al., 2005). Os resultados indicaram títulos bacterianos significativamente inferiores em alguns eventos transgênicos para o gene $d 4 e 1$ em comparação àqueles de plantas não transgênicas e inoculadas com Xcc. Desta forma, sugere-se a potencial ação direta do respectivo peptídeo antimicrobiano (D4E1) contra a bactéria causadora do cancro cítrico.

Em resumo, esse robusto estudo mostrou que a expressão do gene $\operatorname{csdl}$ ou do gene $d 4 e 1$ pode aumentar a resistência de alguns eventos transgênicos a doenças bacterianas de citros, em especial, aquelas causadas por Xcc. Portanto, os usos destes genótipos desejáveis se tornam alternativas promissoras no manejo do cancro cítrico, apesar de que, os testes em campo 
sejam necessários para confirmar a validade deste trabalho. Embora, essas estratégias não tenham fornecido uma abordagem eficaz na resistência à CLas, principalmente, 12 meses após a infecção, várias razões são sugeridas para justificar tal insucesso. Presume-se, primeiramente, que $C$ Las, por se tratar de uma bactéria intracelular associada ao floema, possivelmente, tenha menor exposição a determinadas proteínas em relação a outros patógenos extracelulares, como a Xcc. Além disso, o complexo patossistema de CLas ainda permanece incerto, dificultando a adoção de ferramentas biotecnológicas que possam ser utilizadas no melhoramento genético visando a resistência de plantas, auxiliando assim, o manejo desta grave doença que ameaça a citricultura a nível mundial. 


\section{CONCLUSÃO}

Cinco eventos transgênicos que expressam o gene $c s d l$ e outro, expressando o gene $d 4 e 1$, exibiram populações bacterianas reduzidas quando comparados com plantas nãotransgênicas e não mostraram sintomas visíveis de HLB, seis meses após a inoculação de CLas.

A incidência e a severidade de cancro cítrico foram reduzidas em alguns eventos transgênicos, exibindo populações bacterianas significativamente reduzidas quando comparados com as de plantas não transgênicas. Os eventos transgênicos que registraram maiores atividades isoenzimáticas de SOD também exibiram maiores acúmulos de $\mathrm{H}_{2} \mathrm{O}_{2}$ nos tecidos foliares, após a inoculação com Xcc.

A análise de epifluorescência mostrou alta deposição de calose nos elementos de tubo crivado nos tecidos foliares dos eventos transgênicos. Esses resultados sugerem que a calose pode ser uma importante resposta de defesa aos estresses bióticos, resultando em menores populações de $C$ Las e $X c c$. 


\section{REFERÊNCIAS}

ABBÁ, S.; KHOUJA, H.R.; MARTINO, E.; ARCHER, D.B.; PEROTTO, S. SOD1-targeted gene disruption in the ericoid mycorrhizal fungus Oidiodendron maius reduces conidiation and the capacity for mycorrhization. Molecular Plant-microbe Interactions, v.22, n.11, p.14121421, 2009.

ACHOR, D.S.; ETXEBERRIA, E.; WANG, S.Y.; FOLIMONOVA, K.R.; ALBRIGO, C.; ALBRIGO, L.G. Sequence of anatomical symptom observations in citrus affected with huanglongbing disease. Plant Pathology Journal, v.9, n.2, p.56-64, 2010.

AHMAD P.; JALEEL, C.A.; SHARMA, S. Antioxidant defense system, lipid peroxidation, proline-metabolizing enzymes, and biochemical activities in two Morus alba genotypes subjected to $\mathrm{NaCl}$ stress. Journal Plant Physiology, v.57, p.509-517, 2011.

ALBRECHT, U.; BOWMAN, K.D. Transcriptional response of susceptible and tolerant citrus to infection with Candidatus Liberibacter asiaticus. Plant Science, v.185, p.118-130, 2012.

ALEXIEVA, V.; SERGIEV, I.; MAPELLI, S.; KARANOV, E. The effect of drought and ultraviolet radiation on growth and stress markers in pea and wheat. Plant, Cell and Environment, v.24, p.1337-1344, 2001.

ALSCHER, R.G.; ERTURK, N.; HEATH, L.S. Role of superoxide dismutases in controlling oxidative stress in plants. Journal Exp. Botanic, v.53, p.1331-1341, 2002.

ANN, P.J.; KO, W.H.; SU, H.J. Interaction between Likubin bacterium and Phytophthora parasitica in citrus hosts. European Journal of Plant Pathology, v.110, p.1-6, 2004.

ARAÚJO, E.F; ROQUE, N. Taxonomia dos citros. In: MATTOS JUNIOR, D.; NEGRI, J.D.; PIO, R.M.; POMPEU JUNIOR, J. (Ed.) Citros. Campinas: IAC; FUNDAG, Cap.6, p.125-145, 2005.

ARCE, P.; MORENO, M.; GUTIERREZ, M.; GEBAUER, M.; DELL'ORTO, P.; TORRES, H.; ACUNA, I.; OLIGER, P.; VENEGAS, A.; JORDANA, X.; KALAZICH, J.; HOLUIGUE, L. Enhanced resistance to bacterial infection by Erwinia carotovora subsp. atroseptica in transgenic potato plants expressing the attacin or the cecropin SB-37 genes. American Journal of Potato Research, v.76, n.3, p.169-177, 1999.

ASADA, K. The water-water cycle in chloroplasts: scavenging of active oxygens and dissipation of excess photons. Annual Review of Plant Physiology and Plant Molecular Biology, v.50, p.601-639, 1999.

ATTÍLIO, L.B. Transformação genética de laranja doce (Citrus sinensis L. Osbeck) com o gene d4e1 digirido pelos promotores CaMV35S ou AtPP2. 2013. Tese de doutorado - Escola Superior de Agricultura 'Luiz de Queiroz', Universidade de São Paulo, Piracicaba, 2013.

AUBERT, B. Citrus greening disease, a serious limiting factor for citriculture in Asia and Africa. Proceedings International Society of Citriculture, v.2, p.817-820, 1992. 
AZEVEDO, R.A.; ALAS, R.M.; SMITH, R.J.; LEA, P.J. Response of antioxidant enzymes to transfer from elevated carbon dioxide to air and ozone fumigation, in the leaves and roots of wild-type and a catalase-deficient mutant of barley. Plant Physiology, v.104, p.280-292, 1998.

AZEVEDO, R.A.; DAMERVAL, C.; LANDRY, J.; LEA, P.J.; BELLATO, C.M.; MEINHARDT, L.W.; Le GUILLOUX, M.; DELHAYE, S.; TORO, A.A.; GAZIOLA, S.A.; BERDEJO, B.D.A. Regulation of maize metabolism and endosperm protein synthesis by opaque and floury mutations. European Journal of Biochemistry, v.270, p.4898-4908, 2003.

BADAWI, G.H.; YAMAUCHI, Y.; SHIMADA, E.; SASAKI, R.; KAWANO, N.; TANAKA, K.; TANAKA, K. Enhanced tolerance to salt stress and water deficit by overexpressing superoxide dismutase in tobacco (Nicotiana tabacum) chloroplasts. Plant Science, v.166, n.4, p.919-928, 2004.

BAFFANA, A.; DUTT, S.; KUMAR, A.; AHUJA, P.S. The basic and applied aspects of superoxide dismutase. Journal of Molecular Catalysis B-Enzymatic, Florida, v.68, n.2, p.129-138, 2011.

BARBOSA-MENDES, J.M.; MOURÃO FILHO, F.A.A.; BERGAMIN FILHO, A.; HARAKAVA, R.; BEER, S.V.; MENDES, B.M.J. Genetic transformation of Citrus sinensis cv. 'Hamlin' with hrpN gene from Erwinia amylovora and evaluation of the transgenic lines for resistance to citrus canker. Scientia Horticulturae, Amsterdam, v.122, p.109-115, 2009.

BASSANEZI, R.B.; LOPES, S.A.; BELASQUE JR., J.; SPOSITO, M.B.; YAMAMOTO, P.T.; MIRANDA, M.P.; WULFF, N.A. Epidemiologia do huanglongbing e suas implicações para o manejo da doença. Citrus Research \& Technology, v.31, n.1, p.11-23, 2019.

BATAGLIA, O.C.; FURLANI, A.M.C.; TEIXEIRA, J.P.F.; FURLANI, P.R.; GALLO, J.R. Métodos de análise química de plantas. Campinas: Instituto Agronômico, 1983, 48p. (Boletim Técnico, 78).

BEHLAU, F. Epidemiologia do cancro cítrico (Xanthomonas axonopodis pv. citri) em laranja 'Pera' (Citrus sinensis) sob condições de controle químico e cultural. 2006. Tese de Doutorado. Universidade de São Paulo. Piracicaba, SP.

BEHLAU, F.; BELASQUE JR, J. Cancro cítrico: a doença e seu controle, FUNDECITRUS: Araraquara, 2014, 82p.

BELASQUE JR, J. Dinâmica espacial do cancro cítrico, interação com a larva minadora dos citros (Phyllocnistis citrella) e diversidade genética do seu agente causal (Xanthomonas axonopodis pv. citri). 2005. Tese de Doutorado. Universidade de São Paulo. Piracicaba, SP.

BELASQUE JR, J.; BASSANEZI, R.B.; SPOSITO, M.B.; RIBEIRO, L.M.; JESUS JR, W.C. D.; AMORIM, L. Escalas diagramáticas para avaliação da severidade do cancro cítrico. Fitopatologia Brasileira, v.30, n.4, p.387-393, 2005.

BELASQUE JR, J.; GASPAROTO, M.C.G.; MARCASSA, L.G. Detection of mechanical and disease stresses in citrus plants by fluorescence spectroscopy. Applied Optics, v.47, n.11, p.1922-1926, 2008. 
BELASQUE JR, J.; YAMAMOTO, P.T.; MIRANDA, M.P. de; BASSANEZI, R.B.; AYRES, A.J.; BOVÉ, J.M. Controle do huanglongbing no Estado de São Paulo, Brasil. Citrus Research and Technology, v.31, p.53-64, 2010.

BOAVA, L.P.; CRISTOFANI-YALY, M.; MACHADO, M. Physiologic, anatomic, and gene expression changes in Citrus sunki, Poncirus trifoliata and their hybrids after Liberibacter asiaticus infection. Phytopathology, v.107, n.5, p.590-599, 2017.

BONDADA, B.R.; SYVERTSEN, J.P. Concurrent changes in net $\mathrm{CO}_{2}$ assimilation and chloroplast ultrastructure in nitrogen deficient citrus leaves. Environmental and experimental botany, v.54, n.1, p.41-48, 2005.

BONNEMAIN, J.L.; CHOLLET, J.F.; ROCHER, F. Transport of salicylic acid and related compounds. Salicylic acid, v.20, p.43-59, 2013.

BOSCARIOL, R.L.; MONTEIRO, M.; TAKAHASHI, E.K.; CHABREGAS, S.M.; VIEIRA, M.L.C.; VIEIRA, L.G.E; PEREIRA, L.F.P.; MOURÃO FILHO, F.A.A.; CARDOSO, S.C.; CHRISTIANO, R.S.C.; BERGAMIN FILHO, A; BARBOSA, J.M.; AZEVEDO, F.A.; MENDES, B.M.J. Attacin A gene from Tricloplusia ni reduces susceptibility to Xanthomonas axonopodis pv. citri in transgenic Citrus sinensis 'Hamlin'. Journal of the American Society for Horticultural Science, v.131, n.4, p.530-536, 2006.

BOSCARIOL-CAMARGO, R.L.; TAKITA, M.A.; MACHADO, M.A. Bacterial resistance in AtNPR1 transgenic sweet orange is mediated by priming and involves EDS1 and PR2. Tropical Plant Pathology, v.41, n.6, p.341-349, 2016.

BOVÉ, J.M. Huanglongbing: a destructive, new lyemerging, century-old disease of citrus. Journal of Plant Pathology, Bari, v.88, p.7-37, 2006.

BOWDISH, D.M.; DAVIDSON, D.J.; SCOTT, M.G.; HANCOCK, R.E. Immunomodulatory activities of small host defense peptides. Antimicrobial agents and chemotherapy, v.49, n.5, p.1727-1732, 2005.

BOWLER, C.; VAN MONTAGU, M.; INZÉ, D. Superoxide dismutase and stress tolerance. Annual review of plant biology, v.43, n.1, p.83-116, 1992.

BOWMAN, K.D.; ALBRECHT, U.; GRAHAM, J.H.; BRIGHT, D.B Detection of Phytophthora nicotianae and P. palmivora in citrus roots using PCR-RFLP in comparison with other methods. European Journal of Plant Pathology, v.119, n.2, p.143-158, 2007.

BRADFORD, M.M. A rapid and sensitive method for the quantitation of microgram quantities of protein utilizing the principle of protein-dye binding. Anal Biochemistry, v.72, p.248-259, 1976.

BROWN, K. Florida fights to stop citrus canker. Science, Washington, v.292, p.2275-2278, 2001.

BRUNINGS, A.M.; GABRIEL, D.W. Xanthomonas citri: breaking the surface. Molecular Plant Pathology, v.4, p.141-157, 2003. 
BUENO, P.; VARELA, J.; GIMENEZ, G.G.; DELRIO, L.A. Peroxisomal copper, zinc superoxide dismutase: characterization of the isoenzyme from watermelon cotyledons. Plant Physiology, v.108, n.3, p.1151-1160, 1995.

BUTAYE, K.M.J.; CAMMUE, B.P.A; DELAURE, S.L.; DE BOLLE, M.F.C. Approaches to minimize variation of transgene expression in plants. Molecular Breeding, Dordrecht, v.16, p.79-91, 2005.

CALLIES, T. Section 18 restored for bactericide use on Florida citrus. Citrus Industry, 2017.

CARDOSO, S.C; BARBOSA-MENDES, J.M; BOSCARIOL CAMARGO, R.L, CHRISTIANO, R.S., BERGAMIN FILHO, A; VIEIRA, M.L.C, MENDES, B.M.J; MOURÃO FILHO, F.A.A. Transgenic sweet orange (Citrus sinensis L. Osbeck) expressing the attacin A gene for resistance to Xanthomonas citri subsp. citri. Plant Molecular Biology Reporter, v.28, p.185- 192, 2010.

CARY, J.W.; RAJASEKARAN, K.; JAYNES, J.M.; CLEVELAND, T.E. Transgenic expression of a gene encoding a synthetic antimicrobial peptide results in inhibition of fungal growth in vitro and in plant. Plant Science, v.154, n.2, p.171-181, 2000.

CASERTA, R; PICCHI, S.C; TAKITA, M.A; TOMAZ, J.P; PEREIRA; W.E.L; MACHADO, M.A; IONESCU, M; LINDOW, S. Expression of Xylella fastidiosa RpfF in citrus disrupts signalling in Xanthomonas citri subsp. citri and thereby its virulence. Molecular Plant Microbe Interact, v.27, p.1241-1252, 2014.

CDA. COORDENADORIA DE DEFESA AGROPECUÁRIA. Disponível em: <https://www.defesa.agricultura.sp.gov.br/legislacoes/portaria-cda-5-de-20-5-

2019,1281.html >. Acesso em: 18 ago. 2020.

CEMBROWSKA-LECH, D.; KOPROWSKI, M.; KEPCZYŃSKI, J. Germination induction of dormant Avena fatua caryopses by KAR1 and GA3 involving the control of reactive oxygen species $\left(\mathrm{H}_{2} \mathrm{O}_{2}\right.$ and $\left.\mathrm{O}_{2}^{-}\right)$and enzymatic antioxidants (superoxide dismutase and catalase) both in the embryo and the aleurone layers. Journal of Plant Physiology, v.176, p.169-179, 2015.

CHAMNONGPOL, S.; WILLEKENS, H.; LANGEBARTELS, C.; VAN MONTAGU, M.; INZÉ, D.; VAN CAMP, W. Transgenic tobacco with a reduced catalase activity develops necrotic lesions and induces pathogenesis-related expression under high light. The Plant Journal, v.10, n.3, p.491-503, 1996.

CHAPOT, H. The citrus plant. In: HÄFLINGER, E. (Ed.). Citrus. Basle: CIBA-GEIGY, p.1420, 1975.

CHEN, J.; PU, X.; DENG, X.; LIU, S.; LI, H.; CIVEROLO, E.A. Phytoplasma related to 'Candidatus Phytoplasma asteris' detected in citrus showing huanglongbing (yellow shoot disease) symptoms in Guangdong, P.R. China. Phytopathology, v.99, p.236-242, 2009.

CHEN, X.Y.; KIM, J.Y. Callose synthesis in higher plants. Plant Signaling \& Behavior, v.4, n.6, p.489-492, 2009.

COLETTA-FILHO, H.D.; CARLOS, E.F.; ALVES, K.C.S.; PEREIRA, M.A.R.; BOSCARIOL-CARMARGO, R.L.; SOUZA, A.A.; MACHADO, M.A. In plant multiplication 
and graft transmission of 'Candidatus Liberibacter asiaticus' revealed by Real Time PCR. European Journal of Plant Pathology, Amsterdan, v.126, p.53-60, 2010.

COLETTA-FILHO, H.D.; TAKITA, M.L.P.; CARLOS, E.F.; MACHADO, M.A. A bactéria 'Candidatus Liberibacter' em plantas com huanglongbing (ex-greening) no Estado de São Paulo. Laranja, Cordeirópolis, v.25, p.367-374, 2004.

COLLINGE, D.B.; LUND, O.S.; THORDAL-CHRISTENSEN, H. What are the prospects for genetically engineered, disease resistant plants? European Journal of Plant Pathology, Dordrecht, v.121, p.217-213, 2008.

COMPTON, A.H. Physical Review, 21, 1923. 483p.

DA GRAÇA, J.V.; DOUHAN, G.W.; HALBERT, M.L.; KEREMANE, R.F.L; VIDALAKIS, G.; ZHAO, H. Huanglongbing: An overview of a complex pathosystem ravaging the world's citrus. Journal of Integrative Plant Biology, v.58, p.373-387, 2016.

DAS, A.K. Citrus canker-A review. Journal of Applied Horticulture, v.5, n.1, p.52-60, 2003.

DAVIES, F.; ALBRIGO, L. Citrus. Wallingford: CAB International, 1994. 254p.

DEL RIO, D.; STEWART, A.J.; PELLEGRINI, N. A review of recent studies on malondialdehyde as toxic molecule and biological marker of oxidative stress. Nutrition, metabolism and cardiovascular diseases, v.15, n.4, p.316-328, 2005.

DEL RIO, L.A.; PASTORI, G.M.; PALMA, J.M.; SANDALIO, L.M.; SEVILLA, F.; CORPAS, F.J.; HERNANDEZ, J.A. The activated oxygen role of peroxisomes in senescence. Plant Physiology, v.116, n.4, p.1195-1200, 1998.

DINANT, S.; CLARK, A.M.; ZHU, Y.; VILAINE, F.; PALAUQUI, J.C.; KUSIAK, C.; THOMPON, G.A. Diversity of the superfamily of phloem lectins (phloem protein 2) in angiosperms. Plant Physiology, v.131, p.114-128, 2003.

DORDAS, C. Role of nutrients in controlling plant diseases in sustainable agriculture. A review. Agronomy for sustainable development, v.28, n.1, p.33-46, 2008.

DUBEY, D.; PANDEY, A. Effect of nickel (Ni) on chlorophyll, lipid peroxidation and antioxidant enzymes activities in black gram (Vigna mungo) leaves. International Journal of Science and Nature, v.2, n.2, p.395-401, 2011.

DUTT, M.; ANANTHAKRISHNAN, G.; JAROMIN, M.K.; BRLANSKY, R.H.; GROSSER, J.W. Evaluation of four phloem-specific promoters in vegetative tissues of transgenic citrus plants. Tree Physiology, Oxford, v.32, n.1, p.83-93, 2012.

ELLINGER, D.: NAUMANN, M.: FALTER, C.; ZWIKOWICS, C.; JAMROW, T.; MANISSERI, C.; VOIGT, C. A. Elevated early callose deposition results in complete penetration resistance to powdery mildew in Arabidopsis. Plant Physiology, v.161, n.3, p.1433-1444, 2013.

ELMAYAN, T; VAUCHERET, H. Expression of single copies of a strongly expressed 35S transgene can be silenced post-transcriptionally. The Plant Journal, v.9, n.6, p.787-797, 1996. 
ELSTNER, E.F. Mechanisms of oxygen activation in diferent compartments of plant cells. In: PELL, E.J; STEFFEN, K.L (Ed.) Active oxygen/oxidative stress and plant metabolism. Rockville, MD: American Society of Plant Physiologist, 1991, p.13-15.

ENRIQUE, R.; SICILIANO, F.; FAVARO, M.A.; GERHARDT, N.; ROESCHLIN, R.; RIGANO, L.; MARANO, M.R. Novel demonstration of RNAi in citrus reveals importance of citrus callose synthase in defence against Xanthomonas citri subsp. citri. Plant biotechnology journal, v.9, n.3, p.394-407, 2011.

ETXEBERRIA, E.; GONZALEZ, P.; ACHOR, D.; ALBRIGO, G. Anatomical distribution of abnormally high levels of starch in HLB-affected Valencia orange trees. Physiological and Molecular Plant Pathology, v.74, n.11, p.76-83, 2011.

FAO. FAOSTAT. Disponível em: <http://faostat3.fao.org/home/>. Acesso em: 10 set. 2020.

FEICHTENBERGER, E.; BASSANEZI, R.B.; SPÓSITO, M.B.; BELASQUE JR, J. Doenças dos citros (Citrus spp.). In: KIMATI, H.; AMORIM, L.; REZENDE, J.A.M.; BERGAMIN FILHO, A.; CAMARGO, L.E.A. (Eds.) Manual de Fitopatologia. Doenças das plantas cultivadas. São Paulo. Agronômica Ceres, v.2, 4.ed. 2005. pp. 239-269.

FOLIMONOVA, S.Y.; ROBERTSON, C.J.; GARNSEY, S.M.; GOWDA, S.; DAWSON, W.O. Examination of the responses of different genotypes of citrus to Huanglongbing (citrus greening) under different conditions. Phytopathology, v.99, p.1346-1354, 2009.

FOYER, C.H.; DESCOURVIERES, P.; KUNERT, K.J. Protection against oxygen radicals: An important defense mechanism studied in transgenic plants. Plant physiology, v.17, n.5, p.507$523,1994$.

FOYER, C.H.; NOCTOR, G. Redox homeostasis and antioxidant signaling: A metabolic interface between stress perception and physiological responses. Plant, Cell and Environment, v.17, n.7, p.1866-1875, 2005.

FU, X.Z.; CHEN, C.W.; WANG, Y.; LIU, J.H.; MORIGUCHI, T. Ectopic expression of MdSPDS1 in sweet orange (Citrus sinensis Osbeck) reduces canker susceptibility: involvement of $\mathrm{H}_{2} \mathrm{O}_{2}$ production and transcriptional alteration. BMC Plant Biology, v.11, p.55, 2011.

FUNDECITRUS. Disponível em: <www.fundecitrus.com.br> acesso em: 25 out. 2020.

GABAY, J.E. Ubiquitous natural antibiotics. Science, v.264, n.5157, p.373-374, 1994.

GABRIEL, D.W; KINGSLEY, M.T.; HUNTER, J.E.; GOTTWALD, T., Reinstatement of Xanthomonas citri (ex Hasse) and X. phaseoli (ex Smith) to species and reclassification of all $X$. campestris pv. citri strains, International Journal Systematic Bacteriology, v.39, p.1422, 1989.

GARRAN, S.M. 1988. Quantitative resistance to the nursery type of citrus canker. M.S. Thesis, University of Florida, Gainesville.

GHORBEL, R.; DOMINGUEZ, A.; NAVARRO, L.; PEÑA, L. High efficiency genetic transformation of sour orange (Citrus aurantium L.) and production of transgenic trees containing the coat protein gene of citrus tristeza virus. Tree Physiology, v.20, p.1183-1189, 2000. 
GIANNOPOLITIS, C.N.; RIES, S.K. Superoxide dismutases. I. Occurrence in higher plants. Plant Physiology, v.59, p.309-314, 1977.

GMITTER, F.G. Huanglongbing (Citrus greening disease) and pathways toward genetic management of the disease. In XXIV conference, Plant and animal genome, Florida, USA, 2016.

GOBEL, Y.; KOLETZKO, B.; BOHLES, H.J.; ENGELSBERGER, I.; FORGET, D.; LE BRUN, A.; ZIMMERMANN, A. Parenteral fat emulsions based on olive and soybean oils: a randomized clinical trial in preterm infants. Journal of Pediatric Gastroenterology and Nutrition, v.37, n.2, p.161-167, 2003.

GOLDSCHIMIDT, E.E.; KOCK, K.E. Citrus. In: ZAMSKI E.; SCHAFFER, A.A.; eds. Photoassimilate Distribution in Plants and Crops. New York, NY: Marcel Dekker, Inc., p.797-824, 1996.

GOTTWALD, T.R. Citrus canker and citrus huanglongbing, two exotic bacterial diseases threatening the citrus industries of the Western Hemisphere. Outlooks Pest Management, London, v.18, n.6, p.274-279, 2007.

GOTTWALD, T.R. Current epidemiological understanding of citrus huanglongbing. Annual Review of Phytopatholgy, v.48, p.119-139, 2010.

GOTTWALD, T.R.; GRAHAM, J.H. A device for precise and nondisruptive stomatal inoculation of leaf tissue with bacterial pathogens. Phytopathology, v.82, p.930-935, 1992.

GOTTWALD, T.R.; GRAHAM, J.H.; CIVEROLO, E.L.; BARRET, H.C.; HEARN, C.J. Differential host range reaction of citrus and citrus relatives to citrus canker and citrus bacterial spot determined by leaf mesophyll susceptibility. Plant Disease, v.77, p.1004-1009, 1993.

GOTTWALD, T.R.; HUGHES, G.; GRAHAM, J.H.; SUN, X.; RILEY, T. The citrus canker epidemic in Florida: the scientific basis of regulatory eradication policy for an invasive species. Phytopathology, v.91, p.30-34, 2001.

GOTTWALD, T.R.; SUN, X.; RILEY, T.; GRAHAM, J. H.; FERRANDINO, F.; TAYLOR, E.L. Geo-referenced spatiotemporal analysis of the urban citrus canker epidemic in Florida. Phytopathology, v.92, p.361-377, 2002.

GRAFTON-CARDWELL, E.E.; STELINSKI, L.L.; STANSLY, P.A. Biology and management of Asian citrus psyllid, vector of the huanglongbing pathogens. Annual Review of Entomology, v.58, p.413-432, 2013.

GRAHAM, J. H.; GOTTWALD, T. R.; CUBERO, J.; ACHOR, D. S. Xanthomonas axonopodis pv. citri: factors affecting successful eradication of citrus canker. Molecular plant pathology, v.5, n.1, p.1-15, 2004.

GRAHAM, J. H.; GOTTWALD, T. R.; RILEY, T.D.; ACHOR, D. Penetration through leaf stomata and growth of strains of Xanthomonas campestris in citrus cultivars varying in susceptibility to bacterial diseases. Phytopathology, v.82, p.1319-1325, 1992. 
GRAHAM, J. H.; GOTTWALD, T.R. Variation in aggressiveness of Xanthomonas campestris pv. citrumelo associated with citrus bacterial spot in Florida citrus nurseries. Phytopathology, v.80, n.2, 190-196, 1990.

GRAHAM, J.H.; MENGE, J.A. Root health: fungal diseases. In: Timmer LW, Duncan LW, eds. Citrus Health Management, St Paul, MN, USA: APS Press, p.126-35, 1990.

GRATÃO, P.L.; POLLE, A.; LEA, P.J.; AZEVEDO, R.A. Making the life of heavy metalstressed plants a little easier. Functional Plant Biology, v.32, p.481-494, 2005.

GROPPO, M.; PIRANI, J.R; SALATINO, M.L., BLANCO, S., KALLUNKI, J.A. Phylogeny of Rutaceae based on two non-coding regions from cpDNA. American Journal of Botany, v.95, n.8, p.985-1005, 2008.

GRUPO PAULISTA DE ADUBAÇÃO E CALAGEM PARA CITROS. Recomendações de adubação e calagem para citros no Estado de São Paulo. Cordeirópolis: Laranja, 1994, 27p. (Edição Especial).

GUO, Y.P.; ZHOU, H.F.; ZHANG, L.C. Photosynthetic characteristics and protective mechanisms against photooxidation during high temperature stress in two citrus species. Science Horticulturae, v.108, p.260-267, 2006.

GURR, S.J.; RUSHTON, P.J. Engineering plants with increased disease resistance: how are we going to express it? Trends in biotechnology, v.23, n.6, p.283-290, 2005.

HALBERT, S.E.; MANJUNATH, K.L. Asian citrus psyllid (Sternorrhyncha: Psyllidae) and greening disease of citrus: a literature review and assessment of risk in Florida. Florida Entomologist, v.87, p.330-353, 2005.

HALLIWELL, B.; GUTTERIDGE, J.M.C. Free radicals and antioxidants in the year 2000: a historical look to the future. Annals of the New York Academy of sciences, v.899, n.1, p.136$147,2000$.

HANEKLAUS, S.; BLOEM, E.; SCHNUG, E. Sulfur interactions in crop ecosystems. In Sulfur in Plants an Ecological Perspective, v.1, p.17-58, 2001.

HEATH, R.L.; PACKER, L. Photoperoxidationin isolated chloroplasts: II. Role of electron transfer. Archives of Biochemistry and Biophysics, v.125, p.850-857, 1968.

HUANG, Y.; NORDEEN, R.O.; DI, M.; OWENS, L.D.; MCBEATH, J.H. Expression of an engineered cecropin gene cassette in transgenic tobacco plants confers disease resistance to Pseudomonas syringae pv. tabaci. Phytopathology, v.87, n.5, p. 494-499, 1997.

HUBER, D.M.; GRAHAM, R.D. The Role of Nutrition in Crop Resistance. Mineral nutrition of crops: fundamental mechanisms and implications, v.18, n.12, p.169, 1999.

INOUE, H.; OHNISHI, J.; ITO, T.; TOMIMURA, K.; MIYATA, S.; IWANAMI, T.; ASKIHARA, W. Enhancel prolifation and efficient transmission of Candidatus Liberibacter asiaticus by adult Diaphorina citri after acquisition feeding in nymphal stage. Annals of Applied Biology, v.155, p.29-36, 2009. 
INSTITUTO BRASILEIRO DE GEOGRAFIA E ESTATÍSTICA. Levantamento Sistemático da produção agrícola. Disponível em: http://www.sidra.ibge.gov.br/bda/agric. Acesso em: 10 ago. 2020 .

JAGOUIEX, E.S.; BOVE, J.M.; GARNIER, M. The phloem-limited bacterium of greening disease of citrus is a member of the a-subdivision of the proteobacteria. International Journal of Systematic Bacteriology, v.44, p.379-386, 1994.

JOHNSON, E.G.; WU, J.; BRIGHT, D.B.; GRAHAM, J.H. Association of "Candidatus Liberibacter asiaticus" root infection, but not phloem plugging with root loss on huanglongbing-affected trees prior to appearance of foliar symptoms. Plant Pathology, v.63, n.2, p.290-298, 2014.

JONES, J.B; HUBER, D.M. The role of magnesium in plant disease. Plant and Soil, v.368, n.1-2, p.73-85, 2013.

KOBAYASHI, S.; UCHIMIYA, H. Expression and integration of a foreign gene in orange (Citrus sinensis Osb.) protoplasts by direct DNA transfers. Japanese Journal of Genetics, Mishima, v.64, p.91-97, 1989.

KOH, E.J.; ZHOU, L.; WILLIAMS, D.S.; PARK, J.; DING, N.; DUAN, Y.P.; KANG, B.H. Callose deposition in the phloem plasmodesmata and inhibition of phloem transport in citrus leaves infected with 'Candidatus Liberibacter asiaticus'. Protoplasma, v.249, n.3, p.687-697, 2012.

KUMAR, N.; EBEL, R.C.; ROBERTS, P.D. SOD activity in Xanthomonas axonopodis pv. citri infected leaves of kumquat. Journal of Horticulturae Science and Biotechnology, v.86, p.6268, 2011.

LABANCA, E.R.G. Purificação parcial de elicitores presentes em Saccharomyces cerevisiae: atividade como indutores de resistência em pepino (Cucumis sativus) contra Colletotrichum Iagenarium e da síntese de gliceolinas em soja (Glycine max). 2002. Tese de Doutorado. Universidade de São Paulo. Piracicaba, SP.

LAEMMLI, U.K. Cleavage of structural proteins during the assembly of the head of bacteriophage T4. Nature, v.227, n.5259, p.680-685, 1970.

LEITE JR, R.P; MOHAN, S.K; PEREIRA, A.L; CAMPACCI, C.A. Integrated control of citrus canker: effect of genetic resistance and application of bactericides. Fitopatologia Brasileira, v.12, p.257-263, 1987.

LI, W.B.; ABAD, J.A; FRENC-MONAR, R.D.; RASCOE, J.; WEN, A.; GUDMESTAD, N.C.; SECOR, G.A.; LEE, I.M.; DUAN, Y. Multiplex real-time PCR for detection, identification and quantification of 'Candidatus Liberibacter solanacearum' in potato plants with zebra chip. Journal of Microbiol Methods, v.78, n.59-65, 2009.

LI, W.B.; LEVY, L.; HARTUNG, J.S. Quantitative distribution of 'Candidatus Liberibacter asiaticus' in citrus plants with citrus huanglongbing. Phytopathology, v.99, p.139-44, 2009.

LOMBI, E.; SUSINI, J. Synchrotron-based techniques for plant and soil science: opportunities, challenges and future perspectives. Plant and Soil, v.320, n.1-2, p.1-35, 2009. 
LOPES, S.A.; BERTOLINI, E.; FRARE, G.F.; MARTINS, E.C.; WULFF, N.A.; TEIXEIRA, D.C.; FERNANDES, N.G.; CAMBRA, M. Graft transmission efficiencies and multiplication of 'Candidatus Liberibacter americanus' and ' $\mathrm{Ca}$.Liberibacter asiaticus' in citrus plants. Phytopathology, Saint Paul, v.99, n.3, p.301-306, 2009.

LOPES, S.A.; FRARE, G.F. Graft transmission and cultivar reaction of citrus to Candidatus Liberibacter americanus. Plant Disease, v.92, p.21-24, 2009.

LOPEZ-MARTINEZ, L.X.; OLIART-ROS, R.M.; VALERIO-ALFARO, G.; LEE, C.H.; PARKIN, K.L.; GARCIA, H.S. Antioxidant activity, phenolic compounds and anthocyanins content of eighteen strains of Mexican maize. Food Science and Technology, v.42, n.6, p.1187-1192, 2009.

LOPRASERT, S.; VATTANAVIBOON, P.; PRAITUAN, W.; CHAMNONGPOL, S.; MONGKOLSUK, S. Regulation of oxidative stress protective enzymes, catalase and superoxide dismutase in Xanthomonas - a review. Gene, v.179, p.5188-5194, 1996.

LU, Y.; FENG, Z.; BIAN, L.; XIE, H.; LIANG, J. miR398 regulation in rice of the responses to abiotic and biotic stresses depends on $c s d l$ and $c s d 2$ expression. Functional Plant Biology, v.38, n.1, p.44-53, 2011.

LUNA, E.; PASTOR, V.; ROBERT, J.; FLORS, V.; MAUCH-MANI, B.; TON, J. Callose deposition: a multifaceted plant defense response. Molecular Plant-Microbe Interactions, v.24, n.2, p.183-193, 2011.

MABBERLEY, D.J. A classification of edible Citrus (rutaceae). Telopea, Camberra, v.7, p.167-172, 2008.

MACHADO, M.A.; CRISTOFANI, M.; AMARAL, A.M.; OLIVEIRA, A.C. Genética, melhoramento e biotecnologia de citros. In: MATTOS JUNIOR, D.; NEGRI, J.R.; PIO, R.M.; POMPEU JUNIOR, J. (Ed.). Citros. Campinas: IAC; Fundag, p. 223-227, 2005.

MACHADO, M.A.; CRISTOFANI-YALY, M.; BASTIANEL, M. Breeding, genetic and genomic of citrus for disease resistance. Revista Brasileira de Fruticultura, Jaboticabal, v.33, n.1, p.34-45, 2011.

MAFRA, V.; KUBO, K.S.; ALVES-FERREIRA, M.; RIBEIRO-ALVES, M.; STUART, R. M.; BOAVA, L.P.; MUNARI, C.M.; MACHADO, M.A. Reference genes for accurate transcript normalization in citrus genotypes under different experimental conditions. PLoS One, v.7, n.2, p.31263-31263, 2012.

MAFRA, V.; MARTINS, P.K.; FRANCISCO, C. S.; RIBEIRO-ALVES, M.; FREITASASTÚA, J.; MACHADO, M.A. Candidatus Liberibacter americanus induces significant reprogramming of the transcriptome of the susceptible citrus genotype. BMC Genomics, v.14, n.247, 2013.

MALAVOLTA, E.; CABRAL, C.P.; PRATES, H.S.; OLIVEIRA, S.C.; LAVRES, J.; MALAVOLTA, M.; MORAES, M.F. Composição mineral de folhas de citros afetadas por declínio, amarelinho (CVC), morte súbita e Huanglongbing (HLB). Informações agronômicas, n.110, 2005. 
MARCOLINI, C.D.M.; CARLOS, E.F.; BRUMER, S.; POMPEU JR., J.; CARVALHO, M.C.C. Citrumelos e citrandarins na região citrícola do Paraná. Citrus Research \& Technology, v.36, n.2, 2015.

MARCOS, J.F.; MUNOZ, A.; PEREZ-PAYA, E.; MISRA, S.; LOPEZ-GARCIA, B. Identification and rational design of novel antimicrobial peptides for plant protection. Annual Review of Phytopathology, v.46, p.273-301, 2008.

MARENGO, S. Mapeamento genético de tangerina sunki e Poncirus trifoliata para resistência ao huanglongbing (greening) dos citros. 2009. 85 p. Dissertação (Mestrado em Genética, Melhoramento Vegetal e Biotecnologia) - Instituto Agronômico de Campinas, Campinas, 2009.

MARSCHNER, H. Marschner's mineral nutrition of higher plants. Academic press, 2012.

MARTÍNEZ, Y; LLAUGER, R; BATISTA, L; LUIS, M; IGLESIAS, A; COLLAZO, C; PEÑA, I; CASÍN, JC; CUETO, J; TABLADA, L.M. First report of 'Candidatus Liberibacter asiaticus' associated with huanglongbing in Cuba. Plant Pathology, v.58, p.389-389, 2009.

MEHDY, M.C. Involvement of active oxygen species in plant defense against pathogens. Plant Physiology, v.105, p.467-472, 1994.

MENDES, B.M.J.; CARDOSO, S.C.; BOSCARIOL-CAMARGO, R.L.; CRUZ, R.B.; MOURÃO FILHO, F.A.A.; BERGAMIN FILHO, A. Reduction in susceptibility to Xanthomonas axonopodis pv. citri in transgenic Citrus sinensis expressing the rice Xa21 gene.

Plant Pathology, Leicestershire, v.59, p.68-75, 2010.

MENG, Y.; KATSUMA, S.; DAIMON, T.; BANNO, Y.; UCHINO, K.; SEZUTSU, H.; SHIMADA, T. The silkworm mutant lemon (lemon lethal) is a potential insect model for human sepiapterin reductase deficiency. Journal of Biological Chemistry, v.284, n.17, p.11698$11705,2009$.

MENTAG, R.; LUCKEVICH, M.; MORENCY, M.J.; SÉGUIN, A. Bacterial disease resistance of transgenic hybrid poplar expressing the synthetic antimicrobial peptide $d 4 e 1$. Tree Physiology, v.23, p.405-411, 2003.

MITTER, R. Oxidative stress, antioxidants and stress tolerance. Trends in plant Science, v.7, p.9405-410, 2002.

MITTER, R.; VANDERAUWERA, S.; GOLLERY, M.; VAN BREUSEGEM, F. Reactive oxygen gene network of plants. Trends in plant science, v.9, n.10, p.490-498, 2004.

MONTANHA, G.S.; RODRIGUES, E.S.; MARQUES, J.P.R.; DE ALMEIDA, E.; DOS REIS, A.R.; CARVALHO, H.W.P. X-ray fluorescence spectroscopy (XRF) applied to plant science: challenges towards in vivo analysis of plants. Metallomics, 2020.

MORAES, T.S. Transformação genética de tomateiro (Solanum lycopersicum cv. 'MicroTom') e de laranja doce (Citrus sinensis L. Osbeck) com o gene csd1 (superóxido dismutase do cobre e do zinco), isolado de Poncirus trifoliata. 2015. Tese de Doutorado. Universidade de São Paulo. Piracicaba, SP. 
MOURÃO FILHO, F.A.A.; STIPP, L.C.L.; MENDES, B.M.J. Perspectivas da produção e utilização de transgênicos para o controle do huanglongbing. Citrus Research \& Technology, Cordeirópolis, v.31, n.1, p.91-100, 2010.

MURRAY, M.G.; THOMPSON, W.F. Rapid Isolation of high molecular weight plant DNA. Nucleic Acids Research, Oxford, v.8, p.4321-4325, 1980.

NAKASHIMA, K.; KUBOTA, F.; MARUYAMA, T.; GOTO, M. Ionic liquids as a novel solvent for lanthanide extraction. Analytical Sciences, v.19, n.8, p.1097-1098, 2003.

NAVROT, N.; ROUHIER, N.; GELHAYE, E.; JAQUOT, J.P. Reactive oxygen species generation and antioxidant systems in plant mitochondria. Physiologia Plantarum, v.129, n.1, p.185-195, 2007.

NEVES, M.F.; TROMBIN, V.G.; MILAN, P.; LOPES, F.F.; CRESSONI, F.; KALAKI, R.B. O retrato da citricultura brasileira - FEA/USP Ribeirão Preto, p.4, 2012.

NEVES, M.F.; TROMBIN, V.G.; MILAN, P.; LOPES, F.F.; CRESSONI, F.; KALAKI, R. Mapeamento da economia citrícola. In: NEVES, M.F. (Ed.). O retrato da citricultura brasileira. Ribeirão Preto: CitrusBR, 2010.

NIEDZ, R.P.; MCKENDREE, W.L.; SHATTERS JUNIOR, R.G. Electroporation of embryogenic protoplasts of sweet orange (Citrus sinensis (L.) Osbeck) and regeneration of transformed plants. In Vitro Cellular and Developmental Biology-Plant, Columbia, v.39, p.586-594, 2003.

NIIDOME, T.; ANZAI, S.; SONODA, J.; TOKUNAGA, Y.; NAKAHARA, M.; HATAKEYAMA, T.; AOYAGI, H. Effect of amino acid substitution in amphiphilic $\alpha$-helical peptides on peptide-phospholipid membrane interaction. Journal of Peptide Science, v.5, n.7, p.298-305, 1999a.

NIIDOME, T.; URAKAWA, M.; TAKAJI, K.; MATSUO, Y.; OHMORI, N.; WADA, A. Influence of lipophilic groups in cationic $\alpha$-helical peptides on their abilities to bind with DNA and deliver genes into cells. The Journal of Peptide Research, v.54, n.4, p.361-367, 1999b.

OLIVEIRA, T.S.; GRANATO, L.M.; GALDEANO, D.M.; MARQUES, J.P.R.; COERINI, L.F.; FREITAS-ASTÚA, J.; MACHADP, M.A. Genetic analysis of salicylic acid-mediated defenses responses and histopathology in the huanglongbing pathosystem. Citrus Research \& Technology, v.40, p.1-13, 2019.

OSUSKY, M.; OSUSKA, L.; KAY, W.; MISRA, S. Genetic modification of potato against microbial diseases: in vitro and in planta activity of a dermaseptin B1 derivative, MsrA2. TAG - Theoretical and Applied Genetics, v.111, p.711-722, 2005.

PALAZZO, D.A.; MALAVOLTA JÚNIOR, V.A.; NOGUEIRA, E.M.C. Influência de alguns fatores climáticos sobre o índice de infecção de cancro cítrico, causada por Xanthomonas campestris pv. citri, em laranjeira valência (Citrus sinensis), em Bataguassu, M.S. Fitopatologia Brasileira, v.9, p.283-290, 1984.

PARRA, J.R.P.; LOPES, J.R.S.; TORRES, M.L.G.; NAVA, D.E.; PAIVA, P.E.B. Bioecologia do vetor Diaphorina citri e transmissão de bactérias associadas ao huanglongbing. Citrus Research \& Technology, v.31, n.1, p.37-51, 2017. 
PAULY, N.; PUCCIARIELLO, C.; MANDON, K.; INNOCENTI, G.; JAMET, A.; BAUDOUIN, E.; PUPPO, A. Reactive oxygen and nitrogen species and glutathione: key players in the legume-Rhizobium symbiosis. Journal of Experimental Botany, v.57, n.8, p.1769-1776, 2006.

PENG, M.; KUC, J. Peroxidase-generated hydrogen peroxide as a source of antifungal activity in vitro and on tobacco leaf disks. Phytopathology, v.82, n.6, p.696-699, 1992.

PFAFFL, M.W.; HORGAN, G.W.; DEMPFLE, L. Relative expression software tool (REST) for group-wise comparison and statistical analysis of relative expression results in real-time PCR. Nucleic acids research, v.30, n.9, p.36-36, 2002.

PROEBSTING, E.L.; TATE, R. Seasonal changes in nitrate content of fig leaves. Proceedings of the American Society for Horticultural Science, Alexandria, n.60, p.7-10, 1952.

PUSHPANATHAN, M.; POOJA, S.; GUNASEKARAN, P.; RAJENDHRAN, J. Critical Evaluation and Compilation of Physicochemical Determinants and Membrane Interactions of MMGP1 Antifungal Peptide. Molecular pharmaceutics, v.13, n.5, p. 1656-1667, 2016.

QUAN, L.J.; ZHANG, B.; SHI, W.W.; LI, H.Y. Hydrogen peroxide in plants: a versatile molecule of the reactive oxygen species network. Journal of Integrative Plant Biology, v.50, n.1, p.2-18, 2008.

RAEL, L.T.; THOMAS, G.W.; CRAUN, M.L.; CURTIS, C.G.; BAR-OR, R.; BAR-OR, D. Lipid peroxidation and the thiobarbituric acid assay: standardization of the assay when using saturated and unsaturated fatty acids. BMB Reports, v.37, n.6, p.749-752, 2004.

RAJASEKARAN, K.; CARY, J.W.; JAYNES, J.M.; CLEVELAND, T.E. Disease resistance conferred by the expression of a gene encoding a synthetic peptide in transgenic cotton (Gossypium hirsutum L.) plants. Plant Biotechnology Journal, v.3, n.6, p.545 554, 2005.

RAJASEKARAN, K.; STROMBERG, K.D.; CARY, J.W.; CLEVELAND, T.E. Broadspectrum antimicrobial activity in vitro of the synthetic peptide $d 4 e 1$. Journal of Agricultural and Food Chemistry, Davis, v.49, n.6, p.2799-2803, 2001.

RAMADUGU, C.; KEREMANE, M.L.; HALBERT, S.E.; DUAN, Y.; ROOSE, M.; STOVER, E.; LEE, R.F. Long term field evaluation reveals HLB resistance in Citrus relatives. Plant Disease, v.100, n.9, p.1858-1869, 2016.

RAMAKERS, C.; RUIJTER, J.M.; DEPREZ, R.H.L.; MOORMAN, A.F.M. Assumption-free analysis of quantitative real-time polymerase chain reaction (PCR) data. Neuroscience Letters, v.339, p.62-66, 2003.

REGVAR, M.; EICHERT, D.; KAULICH, B.; GIANONCELLI, A.; PONGRAC, P.; VOGELMIKUS, K.; KREFT, I. New insights into globoids of protein storage vacuoles in wheat aleurone using synchrotron soft X-ray microscopy. Journal of Experimental Botany, v.62, n.11, p.3929-3939, 2011.

RIGANO, L.A.; SICILIANO, F.; ENRIQUE, R.; SENDÍN, L.; FILIPPONE, P.; TORRES, P.S.; QUESTA, J.; DOW, J.M.; CASTAGNARO, A.P.; VOJNOV, A.A.; MARANO, M.R. Biofilm formation, epiphytic fitness, and canker development in Xanthomonas axonopodis pv. citri. Molecular Plant-Microbe Interact, v.20, p.1222-1230, 2007. 
SANCHES, A.L.R.; MIRANDA, S.H.G.D.; BELASQUE JR, J.; BASSANEZI, R.B. Análise econômica da prevenção e controle do cancro cítrico no estado de São Paulo. Revista de Economia e Sociologia Rural, v.52, n.3, p.549-566, 2014.

SCHAAD, N.W.; POSTNIKOVA, E.; LACY, G.; SECHLER, A.; AGARKOVA, I.V.; STROMBERG, P. E.; VIDAVER, A. M. Emended classification of Xanthomonas pathogens on citrus. Papers in Plant Pathology, v.29, p.690-695, 2006.

SHANER, G.; FINNEY, R.E. The effect of nitrogen fertilization on the expression of slowmildewing resistance in Knox wheat. Phytopathology, v.67, n.8, p.1051-1056, 1977.

SHARMA, B.D.; HORE, D.K.; GUPTA, S.G. Genetic resources of Citrus of north-eastern India and their potential use. Genetic Resources and Crop Evolution, v.51, p.411-418, 2004.

SHI, Y.; WANG, F.; WAN, B.; BITTER, M.; LEE, S.; BAK, J.; TI, A. Imaging X-ray crystal spectrometer on EAST. Plasma Physics and Controlled Fusion, v.52, n.8, 2010.

SOUTHERN, E.M. Detection of specific sequences among DNA fragments separated by gel electrophoresis. Journal of Molecular Biology, London, v.98, p.503-517, 1975.

STANGARLIN, J.R.; KUHN, O.J.; TOLEDO, M.V.; PORTZ, R.L.; PASCHOLATI, S.F. A defesa vegetal contra fitopatógenos. Scientia Agraria Paranaensis, v.10, n.1, p.18, 2011.

STEINER, H.; HULTMARK, D.; ENGSTROM, A.; BENNICH, H.; BOMAN, H.G. Sequence and specificity of two antibacterial proteins involved in insect immunity. Nature, v.292, n.5820, p.246-248, 1981.

STOVER, E.; BOWMAN, K.; MCCOLLUM, G.; NIEDZ, R.; SHATTERS, JR.R.; HALL, D. Breeding citrus for HLB resistance at the USDA/ARS US Horticultural Research Laboratory, Ft. Pierce, Florida. In: Workshop Proceedings, 2013.

STOVER, E.; SHATTERS, R.; MCCOLLUM, G.; HALL, D.G.; DUAN, Y. Evaluation of Candidatus Liberibacter asiaticus titer in field-infected trifoliate cultivars: preliminary evidence for HLB resistance. Plant biology, v.2, p.90, 2010.

SUNKAR, R.; KAPOOR, A.; ZHU, J.K. Posttranscriptional induction of two Cu/Zn superoxide dismutase genes in Arabidopsis is mediated by downregulation of miR398 and important for oxidative stress tolerance. The Plant Cell, v.18, n.8, p. 2051-2065, 2006.

SWARUP, S.; YANG, Y.; KINGSLEY, M.T.; GABRIEL, D.W. A Xanthomonas citri pathogenicity gene, pthA, pleiotropically encodes gratuitous avirulence on nonhosts. Molecular Plant Microbe Interact, v.5, n.3, p.204-213, 1992.

TATINENI, S.; SAGARAM, U.S.; GOWDA, S.; ROBERTSON, C.J.; DAWSON, W.O.; IWANAMI, T.; WANG, N. In plant distribution of 'Candidatus Liberibacter asiaticus' as revealed by polymerase chain reaction (PCR) and realtime PCR. Phytopatology, v.98, n.5, p.592-599, 2008.

TAVANO, E.C.R. 2013. Transformação genética de Citrus sinensis (L.) Osbeck para resistência a Candidatus Liberibacter ssp. Tese de Doutorado. Universidade de São Paulo. 
TEIXEIRA, D.C.; DANET, J.L.; EVEILLARD, S.; MARTINS, E.C.; JESUS JUNIOR, W.C.; YAMAMOTO, P.T.; LOPES, A.S.; BASSANEZI, R.B.; AYRES, A.J.; SAILLARD, C; BOVÉ, J.M. Citrus huanglongbing in São Paulo State, Brazil: PCR detection of the 'Candidatus' Liberibacter species associated with the disease. Molecular and Cellular Probes, v.19, p.173-179, 2005.

TEIXEIRA, D.C.; WULFF, N.A.; MARTINS, E.C.; KITAJIMA, E.W.; BASSANEZI, R.B.; AYRES, A.J.; EVEILLARD, S.; SAILLARD, C.; BOVÉ, J.M. A phytoplasma closely related to the pigeon pea witches-broom phytoplasma (16Sr IX) is associated with citrus huanglongbing symptoms in the State of São Paulo, Brazil. Phytopathology, v.98, n.9, p.977984, 2008.

TERTIVANIDIS, K.; GOUDOULA, C.; VASILIKIOTIS, C.; HASSIOTOU, E.; PERLTREVES, R.; TSAFTARIS, A. Superoxide dismutase transgene in sugarbeets confer resistance to oxidative agents and the fungus $C$. beticola. Transgenic Research, v.13, p.225-233, 2004.

TONDO, M.L.; PETROCELLI, S.; OTTADO, J.; ORELLANO, E.G. The monofunctional catalase KatE of Xanthomonas axonopodis pv. citri is required for full virulence in citrus plants.

Plos One, v.5, p.10803, 2010.

TRIPATHI, L.; TRIPATHI, J.N.; TUSHEMEREIRWE, W.K. Strategies for resistance to bacterial wilt disease of bananas through genetic engineering. African Journal of Biotechnology, v.3, n.12, p.688-692, 2004.

VALE, F.X.R.; FERNANDES FILHO, E.I.; LIBERATO, J.R.; ZAMBOLIM, L. Quant: software to quantify plant disease severity. In: International Workshop on Plant Disease Epidemiology, v.8, 2001. Ouro Preto. Proceedings...Ouro Preto, 2001. p.160.

VARDI, A.; BLECHMAN, K.; AVIV, D. Genetic transformation of Citrus protoplasts and regeneration of transgenic plants. Plant Science, v.69, n.2, p.199-206, 1990.

VILORIA, Z.; DROUILLAERD, D.L.; GRAHAM, J.H.; GROSSER, J.W. Screening triploid hybrids of Lakeland Limequat for resistance to citrus canker. Plant Disease, v.88, p.10561060, 2004.

WANG, N.; PIERSON, E.A.; SETUBAL, C.; XU, J.; LEVY, J.G.; ZHANG, Y.; LI, J.; RANGEL, L.T.; MARTINS JR, J. The Candidatus Liberibacter-host interface: insights into pathogenesis mechanisms and disease control. Annual Review of Phytopathology, v.55, p.1$32,2017$.

WANG, N.; TRIVEDI, P. Citrus huanglongbing: a newly relevant disease presents unprecedented challenges. Phytopathology, v.103, n.7, p.652-665, 2013.

WANG, Z.; YIN, Y.; HU, H.; YUAN, Q.; PENG, G.; XIA, Y. Development and application of molecular-based diagnosis for 'Candidatus Liberibacter asiaticus', the causal pathogen of citrus huanglongbing. Plant Pathology, v.55, p.630-638, 2006.

WOJTASZEK, P. Oxidative burst: an early plant response to pathogen infection. Biochemistry Journal, v.322, p.681-692, 1997.

XIE, B.; WANG, X.; ZHU, M.; ZHANG, Z.; HONG, Z. CalS7 encodes a callose synthase responsible for callose deposition in the phloem. The Plant Journal, v.65, n.1, p.1-14, 2011. 
YAMAMOTO, P.T; ALVES, G.R; BELOTI, V.H. Manejo e controle do huanglongbing (HLB) dos cítricos. Investigación Agraria, v.16, n.2, p.69-82, 2015.

YANG, L.; HU, C.; LI, N.; ZHANG, J.; YAN, J; DENG, Z. Transformation of sweet orange (Citrus sinensis (L.) Osbeck) with pthA-nis for acquiring resistance to citrus canker disease. Plant Molecular biology, v.75, p.11-23, 2011.

YAO, J.L.; WUB, J.H.; GLEAVE, A.P.; MORRISA, B.A.M. Transformation of citrus embryogenic cells using particle bombardment and production of transgenic embryos. Plant Science, Limerick, v.133, p.175-183, 1996.

YUN, M.H.; TORRES, P.S.; EL OIRDI, M.; RIGANO, L.A.; GONZALEZ-LAMOTHE, R.; MARANO, M.R.; CASTAGNARO, A.P.; DANKERT, M.A.; BOUARAB, K.; VOJNOV, A.A. Xanthan induces plant susceptibility by suppressing callose deposition. Plant Physiology, v.141, p.178-187, 2006.

ZASLOFF, M. Antimicrobial peptides of multicellular organisms. Nature, London, v.415, p.389-395, 2002.

ZHANG, Q.; ZHANG, J.; HUANG, Z.; TAN, S.; GUO, Z. The bactericidal effect of antibacterial peptide from Chinese Oak silkworm on the pathogen of bacterial ulcer and yellow shoot disease in citrus. Acta Sericologica Sinica, v.21, p.77-81, 1995.

ZOU, Z.; XI, W.; HU, Y.; NIE, C.; ZHOU, Z. Antioxidant activity of Citrus fruits. Food Chemistry, v.196, p.885-896, 2016. 